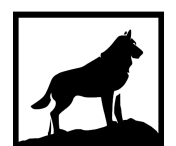

Michigan

Technological

1 8 8 5 University
Michigan Technological University

Digital Commons @ Michigan Tech

\title{
ADDRESSING POLICY CHALLENGES TO WOODY BIOPOWER PRODUCTION: SOCIAL ACCEPTANCE, BIOMASS CERTIFICATION AND LIMITED POLICY SUPPORT
}

John B. Barnett

Michigan Technological University, barnett@mtu.edu

Copyright 2018 John B. Barnett

Recommended Citation

Barnett, John B., "ADDRESSING POLICY CHALLENGES TO WOODY BIOPOWER PRODUCTION: SOCIAL ACCEPTANCE, BIOMASS CERTIFICATION AND LIMITED POLICY SUPPORT", Open Access Dissertation, Michigan Technological University, 2018.

https://doi.org/10.37099/mtu.dc.etdr/708

Follow this and additional works at: https://digitalcommons.mtu.edu/etdr

Part of the Energy Policy Commons 


\title{
ADDRESSING POLICY CHALLENGES TO WOODY BIOPOWER PRODUCTION: SOCIAL ACCEPTANCE, BIOMASS CERTIFICATION AND LIMITED POLICY SUPPORT
}

\author{
By
}

John B. Barnett

\begin{abstract}
A DISSERTATION
Submitted in partial fulfillment of the requirements for the degree of DOCTOR OF PHILOSOPHY in Environmental and Energy Policy
\end{abstract}

MICHIGAN TECHNOLOGICAL UNIVERSITY

2018

(C)2018 J. Brad Barnett 

This dissertation has been approved in partial fulfillment of the requirements for the Degree of DOCTOR OF PHILOSOPHY in Environmental and Energy Policy.

\section{Department of Social Sciences}

Dissertation Advisor: Dr. Barry D. Solomon.

Committee Member: Dr. Dennis R. Becker.

Committee Member: Dr. Donald J. Lafreniere.

Committee Member: Dr. Mark D. Rouleau.

Committee Member: Dr. Adam M. Wellstead.

Department Chair: Dr. Hugh S. Gorman. 


\section{Table of Contents}

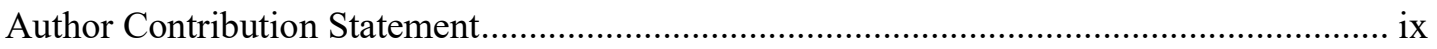

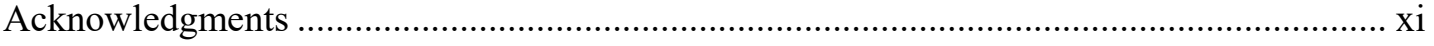

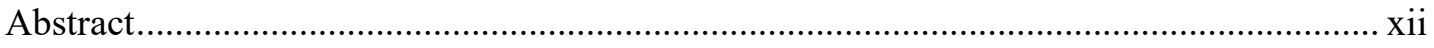

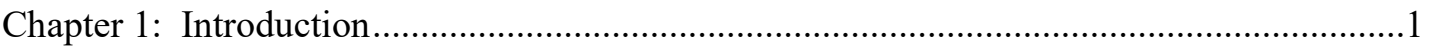

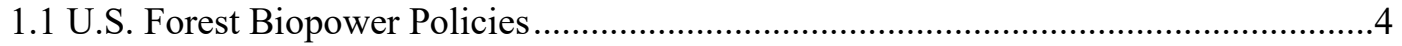

1.2 Social Acceptance of Woody Biomass Production ...........................................................

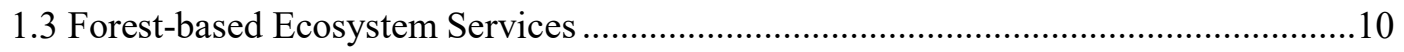

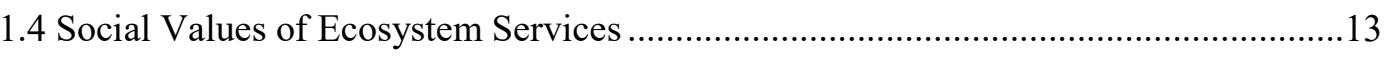

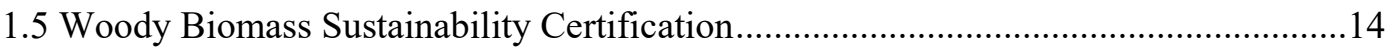

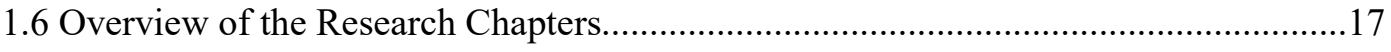

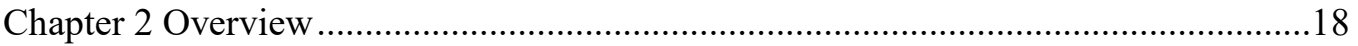

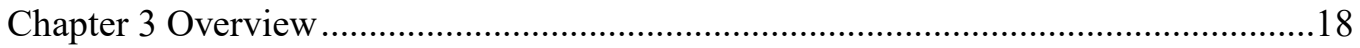

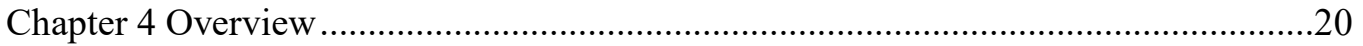

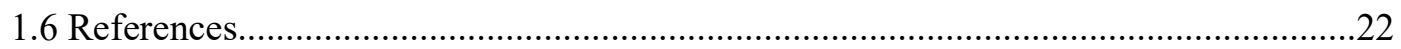

Chapter 2: Dismantling through Dilution: Wisconsin's Renewable Portfolio Standard (RPS) \& Wavering Support for Woody Biopower Production ......................................................... 34

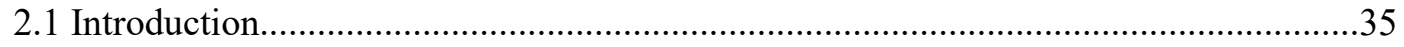

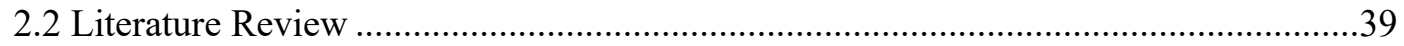

2.2.1 Using Historical Institutionalism to Understand Woody Biopower Policy Change

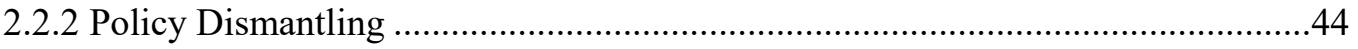

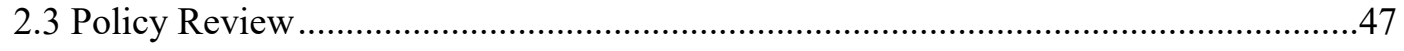

2.3.1 Historic Woody Biopower Output in Wisconsin .................................................47

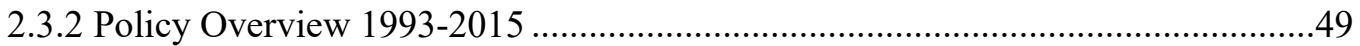

2.3.3 1993 - 1998: Enhancing Energy Independence and Electric Reliability through

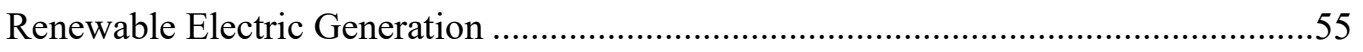

2.3.4 1999 - 2004: Renewable Portfolio Standard \& Climate Change ............................58

2.3.5 2005 - 2010: Policy Layering, Tinkering and Woody Biopower.........................60

2.3.6 2011 - 2015: Dismantling through Tinkering …............................................... 70 
2.4.1 Dismantling the RPS thought Policy Dilution..................................................... 76

2.4.2 The Role of Actors: Complexity in the Forest Products Industry and Absence of

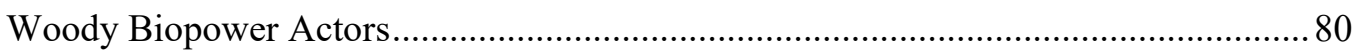

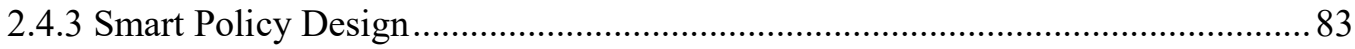

2.4.4 RPS and the Energy Priorities List: Tense Layering ......................................... 83

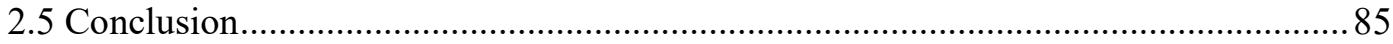

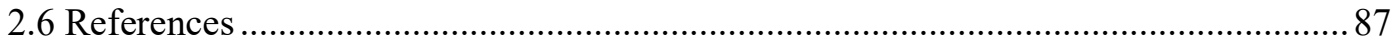

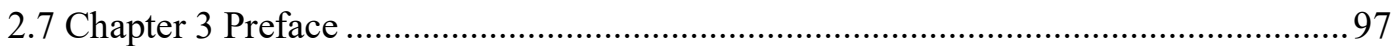

Chapter 3: Deciphering Support for Woody Biomass Production for Electric Power Using

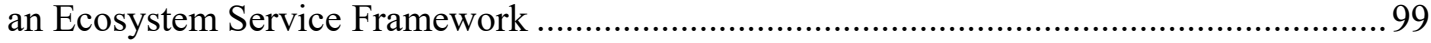

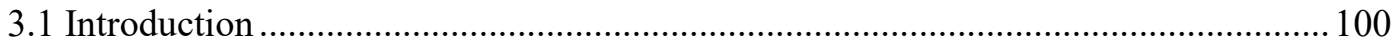

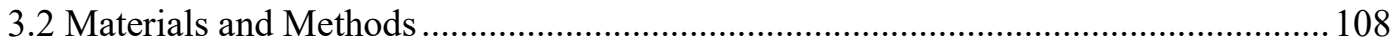

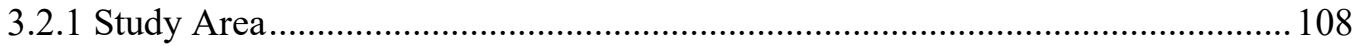

3.2.2 Target Population and Sample Construction ...................................................... 110

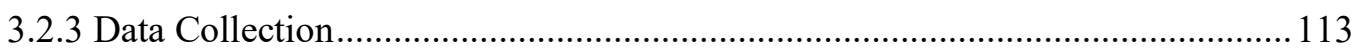

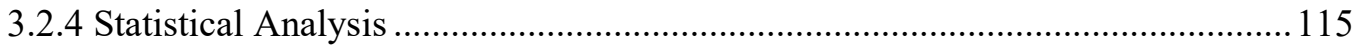

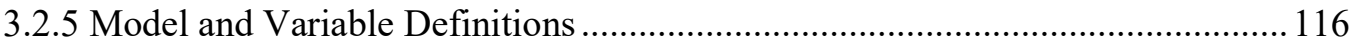

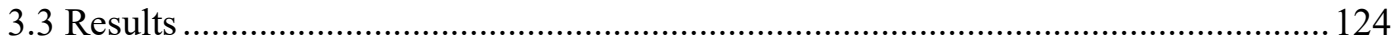

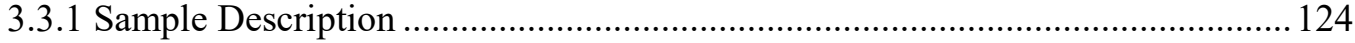

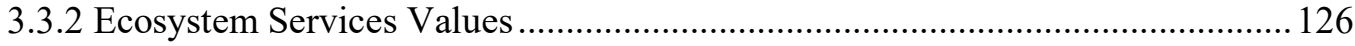

3.3.3 Perception of Forest Biomass Production Effects ............................................. 128

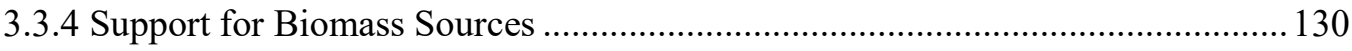

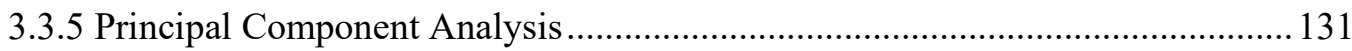

3.3.6 Binomial Logistic Regression Model ............................................................. 133

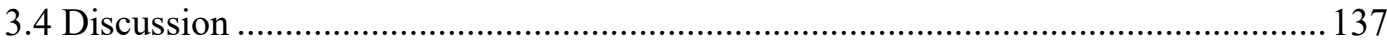

3.4.1 Ecosystem Services Values and Support for Local Biomass Production............. 137

3.4.2 Social Values of Forest Ecosystem Services...................................................... 139

3.4.3 Support for Forest Biomass Production: Sources Matter ................................... 140

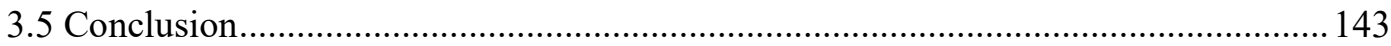

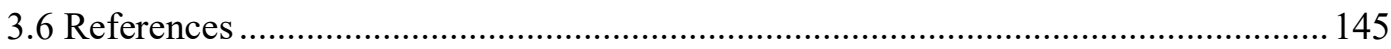


Chapter 4: An Evaluation of the U.K.'s use of SFM Standards to Procure Solid Woody Biomass for Electricity Generation Using Sustainable Bioenergy Criteria ..........................158

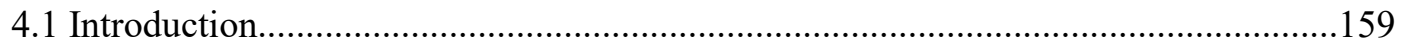

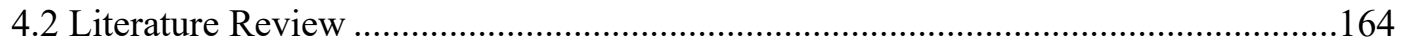

4.2.1 Addressing Sustainability through Certification..................................................164

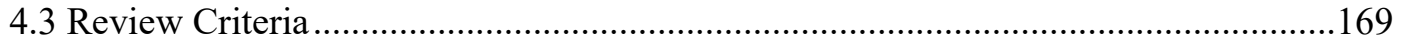

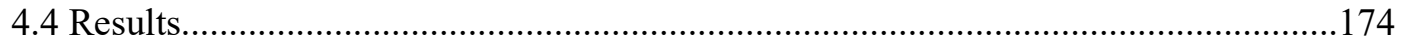

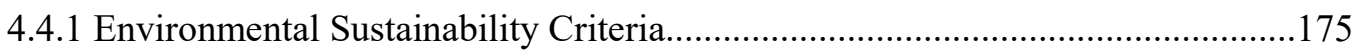

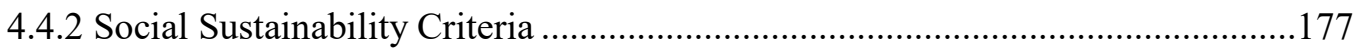

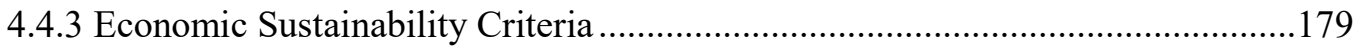

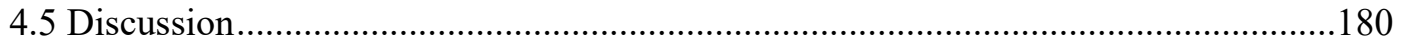

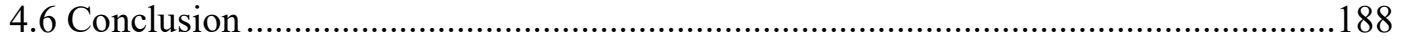

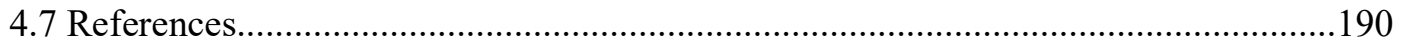

Chapter 5: Conclusions \& Directions for Future Research ...............................................198

5.1 Woody Biopower Development Policy Implications ...............................................200

5.2 Policy Implications for Ecosystem Services Policy Integration ................................203

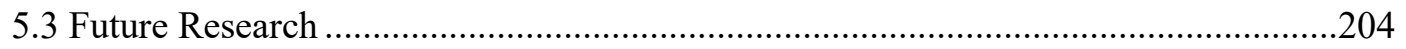

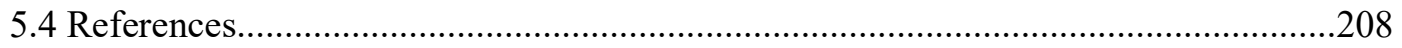




\section{List of Figures}

Figure 1: Wisconsin woody biomass power generation by producer type (1990-2016)

Figure 2: Study area and site of Rothschild biopower facility's biomass procurement zone 110

Figure 3: Importance of forest ecosystem services using five-point Likert scale 127

Figure 4: Importance of forest ecosystem services using $\$ 100$ spending exercise .............. 128

Figure 5: Perceptions of local forest biomass production effects....................................... 129

Figure 6: Support for different sources of forest biomass production

\section{List of Tables}

Table 1: Components of a policy mix 42

Table 2: Historical institutionalism: Summarizing key concepts.

Table 3: Wisconsin legislation and policies impacting the RPS \& woody biopower (19932015)

Table 4: Goals and objectives of Wisconsin policies impacting the RPS and woody biopower (1993-2015).... .53

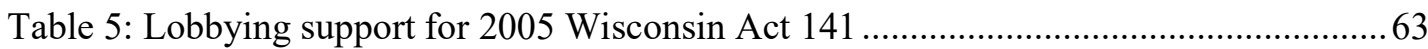

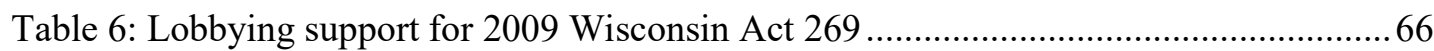

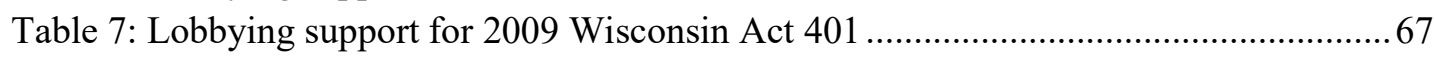

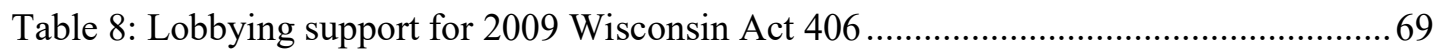

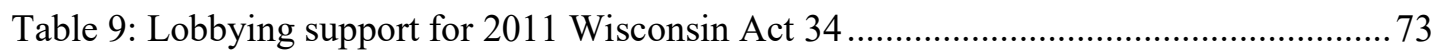

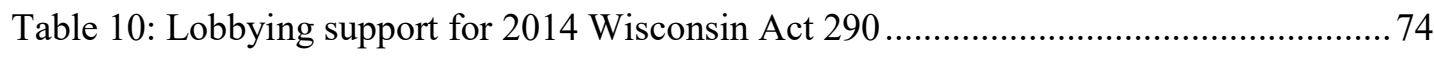

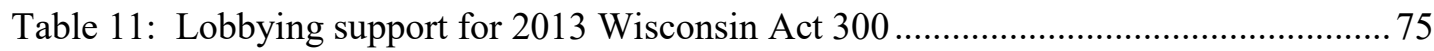

Table 12: Definition and hypothesized coefficient direction of variables used in binomial logistic regression model.

Table 13: Survey response rate

Table 14: Socio-demographic characteristics of Tomahawk survey respondents $(\mathrm{N}=292) .126$

Table 15: Unobservable dimensions of respondents' social value of forest-based ecosystem

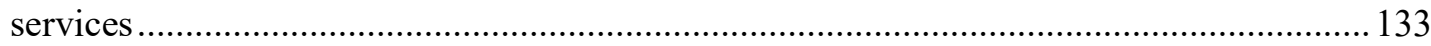

Table 16: Results of logistic regression on forest biomass production support .................... 136

Table 17: Actual and predicted values for forest biomass production support ...................... 136

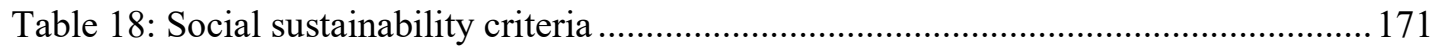

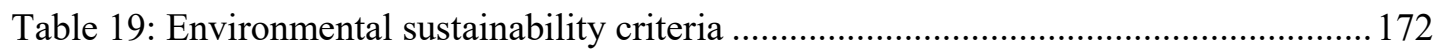

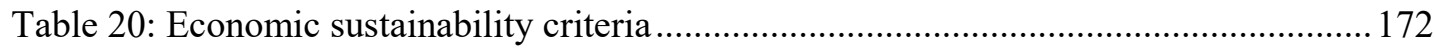

Table 21: Forestry certification scheme inclusion of bioenergy environmental sustainability

criteria 177

Table 22: Forestry certification scheme inclusion of bioenergy social sustainability criteria.

Table 23: Forestry certification scheme inclusion of bioenergy economic sustainability criteria. 


\section{Author Contribution Statement}

The research contained within my dissertation was conducted under the supervision of Professor Barry D. Solomon in the Environmental and Energy Policy Program, Department of Social Sciences, Michigan Technological University, from August 2013 to September 2018. All work included in this dissertation is my own and original, except where I make reference to other authors' work. The work contained in Chapter 3 was funded by National Science Foundation's Partnerships for International Research and Education (PIRE) Program IIA \#1243444 and was part of a multi-national, interdisciplinary research program originally comprised of four case studies. The survey instrument described in Chapter 3 was developed by members of the PIRE research team, and I was responsible for implementation and data collection in the Tomahawk, WI case study. The data analysis and all written work contained in Chapter 3 is my own.

The research chapters included in my dissertation have been submitted, or are in preparation for submission, to journals for publication. I indicate below the submission status of each chapter.

\section{Chapter 2}

Barnett, B. (2018). Dismantling through Dilution: Wisconsin's Renewable Portfolio Standard (RPS) \& Wavering Support for Woody Biopower Production. Manuscript in preparation for submission to Journal of Environmental Policy and Planning. 


\section{Chapter 3}

Barnett, B. (2018). Deciphering Support for Woody Biomass Production for Electric Power Using an Ecosystem Service Framework. Manuscript in preparation for resubmission to Ecosystem Services.

\section{Chapter 4}

Barnett, B. (2016). An Evaluation of the UK's Use of SFM Standards to Procure

Solid Woody Biomass for Electricity Generation Using Sustainable Bioenergy

Criteria. Biofuels, 7(1), 1-11. Published. 


\section{Acknowledgments}

I would like to thank Dr. Barry D. Solomon for his guidance over the past five years.

I appreciate your encouragement, mentorship, and persistence as I meandered my way through.

I would also like to express my appreciation for the feedback and patience I received from my other committee members. Thank you to Drs. Adam Wellstead, Dennis Becker, Donald Lafreniere and Mark Rouleau.

Thank you to those who helped me with my survey work: Kathleen Halvorsen, Jenny Dunn, Aparajita Banerjee, and Cecilia Wallace. I would also like to thank those who responded to the survey in Tomahawk, Wisconsin.

Finally, and most deeply, I would like to thank my wife Erin and daughter Eleanor for your support and sacrifice as I plodded my way through this experience.

This work was supported by the National Science Foundation's Partnerships for International Research and Education (PIRE) Program IIA \#1243444. 


\section{Abstract}

Forestlands have been identified as a valuable resource to mitigate climate change due to the biome's capacity to both sequester greenhouse gases and substitute for fossil fuels. Woody biomass has been proposed as a substitutable input for coalgenerated electricity as economies attempt to transition to renewable power while addressing economic development goals. However, increasing the intensity of forest management for energy production has the potential to result in significant ecological, economic and social consequences at local, regional and global scales. In this context, my dissertation explores the capacity of existing policy frameworks to stimulate and support sustainable power production from forest biomaterials. In Chapter Two, I explore the interactions between shifting goals, actors and institutions in influencing incentives that shape today's policy mix for woody biopower production in Wisconsin. The study's results reveal that the state's shifting focus away from using renewable energy as a means to pursue climate change mitigation and energy security goals combined with an absence of supportive coalitions has resulted in the dismantling of support for the woody biopower policy framework. In Chapter Three, I use data from a household survey of Tomahawk, Wisconsin residents to evaluate support for woody biomass production for power generation. Results show that respondents in biomass producing communities are more supportive of biomass sources such as forestry residues and forestry thinnings than dedicated harvesting operations. In addition, the results indicate that using an xii 
ecosystem services approach can help explain differences in support between these respondents and provide insights into socially acceptable forms of biomass harvesting operations. Chapter Four evaluates the use of sustainable forest management certification programs as a policy instrument to source sustainable woody biomass. The study evaluated the Forest Stewardship Council (FSC) and Sustainable Forestry Initiative (SFI) certification programs using bioenergy sustainability criteria found in the academic literature. The analysis shows a deficiency in these programs to address key criteria pertaining to climate change mitigation and would be improved by coupling sustainable forest management programs with bioenergy sustainability schemes such as designed by the Roundtable on Sustainable Biomaterials. 



\section{Chapter 1: Introduction}

The Intergovernmental Panel on Climate Change predicts that the adoption rate of zero- and low-carbon energy sources must rapidly accelerate in the next three decades to avoid breaching a $2^{\circ} \mathrm{C}$ global temperature increase (IPPC, 2014). If current global greenhouse gas emission levels continue to go unabated, scientists predict that a host of negative consequences will occur including more frequent extreme weather events, rising sea levels threatening coastal populations, destruction of ecosystems and wildlife habitat, changes in global temperatures and precipitation patterns altering food production systems, and more (IPCC, 2007; Lackner \& Sachs, 2005; Reddy et al., 1997). Electricity production is believed to contribute the most global greenhouse gases and represents a significant opportunity for climate change mitigation (Brown \& Sovacool, 2011).

In 2014, global consumption of electricity exceeded 20,500 TWh and it is expected to reach more than 37,000 TWh under the current policy environment (U.S. Energy Information Administration, 2016). In forest resource-rich countries like the United States, Canada, and Finland, electricity production from woody biomass is viewed as a viable option to achieve climate change mitigation and energy goals in addition to goals of economic development, energy security, and opening markets for new wood products (Aguilar, 2015). As of 2014, only 495 TWh of electricity was generated from biomass resources representing approximately $2.4 \%$ of the total global electricity supply and $9.2 \%$ of total global renewable electric generation (U.S. Energy Information Administration, 2016). However, it is estimated that forest 
biomaterials have the capacity to provide up to $18 \%$ of global primary energy by 2050 (Lauri et al., 2014).

The policy response to the potential woody biopower industry has been twofold. On the one hand, some policy makers seek to implement policies to support and grow woody biopower production. In the United States, policymakers at state and federal levels have pursued a patchwork of policies intended to stimulate and support woody bioenergy industry development (Becker et al., 2011; Ebers et al., 2016). Using a systems approach and varying taxonomies to identify and categorize relevant policies, scholars have demonstrated few policies directly target woody biopower production in favor of more general renewable power production goals despite the industry's potential to achieve economic, climate change mitigation, and environmental goals. Their analyses show that the adoption of direct woody biopower supportive policies can dramatically vary geographically even when comparing forest-rich regions within the United States (Becker et al., 2011; Ebers et al., 2016; Lantiainen et al., 2014). At times, the result has been an incoherent policy mix due to incompatible energy, biomass production and environmental protection goals (Abrams et al., 2017). This leads to my first research question: why have supportive woody biopower power policies failed to develop in some states despite the industry's potential to meet economic development and climate change mitigation goals?

On the other hand, a parallel body of literature focuses on assessing the sustainability of the underdeveloped forest bioenergy production due to concerns 
with the effects of potential large-scale deforestation, intensification of forest management practices, and general changes to forest land use. Using the Brundtland Report's definition of sustainable development of meeting today's needs without jeopardizing the ability of future generations to meet their own needs, these scholars have tackled the myriad of current and potential environmental, economic and social shortcomings of forest-based bioenergy (Barnett, 2016; Berger et al., 2013; Cambero \& Sowlati, 2014; Holland et al., 2015; Luzadis et al., 2008). Some countries like the United Kingdom and U.S. states including New York and Maine have turned to third-party forest management certification schemes to ensure forest biomass intended for power production is sourced sustainably (New York State Energy Research \& Development Authority, 2014; State of Maine, 2012; U.K. Department of Energy \& Climate Change, 2014). However, these certification programs were developed originally for the traditional forest products industry. Studies show that the forest management intensity of woody biomass production for wood energy has the potential to exceed that of traditional forest products harvesting operations with more sever ecological impacts (Janowiak \& Webster, 2010). This leads to my second research question: how can sustainable forest management certification schemes ensure the sustainability of forest-based bioenergy?

While a significant amount of research has addressed issues of environmental and economic sustainability, much less attention has been paid to address the social effects of large-scale forest bioenergy land use change and renewable energy development overall (Boström, 2012; Magis \& Shinn, 2009; Wüste \& Schmuck, 
2013). The production of bioenergy feedstocks from forests is often highly controversial (Lattimore et al., 2009). Stakeholder groups often have different thresholds for supporting or opposing bioenergy projects because of the wide range of potential socioeconomic and ecological effects of producing energy from biomass, and these differences are exacerbated by regional, national, and increasing global nature of the woody biomass supply chain required to support international renewable energy goals (Chin et al., 2014). Biomass production has the potential to affect ecosystem services of forests with high social value such as wildlife habitats, timber production, local energy resources (e.g. firewood), aesthetics, and recreation (Gasparatos et al., 2011; Lattimore et al., 2009). Biomass production's impact on these services (and others) may influence the overall social acceptance of creating bioenergy from forest resources as the perception of health and environmental benefits and risks play a crucial role in the public's decision to accept or reject electricity sources (Bronfman et al., 2012). This leads to my third research question: How do perceptions of change to forest-based ecosystem services influence the social acceptance of forest-based bioenergy development?

\subsection{U.S. Forest Biopower Policies}

The U.S. forest biopower policy mix, or the combination of policy instruments and instrument settings which influence the industry, is incredibly complex due to the inclusion of a wide array of actors, multiple levels of government and interactions between several policy subsystems including, but not limited to: energy, 
environmental protection and forest products. In contrast to other forms of renewable power generation like wind and solar, electricity produced from forest biomaterials requires an extensive supply chain made up of biomass producers, biomass harvesters and transport, energy conversion, transmission and distribution, and final consumers. In addition, this supply chain is nested within the traditional forest products industry, which has the potential to compete for feedstock resources in the form of low value pulp wood or assist in generating biomass in the form of integrated harvesting operations to collect slash and forest and mill residues (Luzadis et al., 2008).

Most of federal-level policy interventions directly targeting woody biopower production are financial instruments seeking to reduce the cost of biomass harvesting, transportation, and power production (Lantiainen et al., 2014). The foundation of U.S. woody biopower policy can be traced back to the 1978 passage of the Public Utility Regulatory Policies Act, which stipulated that electric utilities and electric distributors purchase renewable power from qualifying facilities at the same cost as if the utility companies produced the power themselves - referred to as their "avoided costs." This policy, which closely resembles a modern day feed-in-tariff, helped stimulate the construction of early biopower facilities in the 1980s (Lantiainen et al., 2014). The federal production tax credit (PTC), which offers a $\$ 0.023 / \mathrm{kWh}$ credit to qualifying power production facilities using dedicated woody crops (labeled as "closed loop" materials) commencing construction prior to January $1^{\text {st }}, 2018$ (U.S. Department of Energy, 2018b) also serves as a financial incentive. 
Utilities operating combined heat and power (CHP) facilities using woody biomass built after October 3, 2008 are eligible to claim the federal business energy investment tax credit (ITC) of up to $10 \%$ of qualifying expenses (U.S. Department of Energy, 2018a). Other instruments, such as federal loans and grants and green purchasing programs are common financial instruments leveraged to reduce the cost of woody biopower production.

Previous studies show that the state-level policy mix for woody biopower in the United States rarely directly targets the industry in favor of incentivizing the general promotion of renewable power development (Aguilar \& Saunders, 2010; Becker et al., 2011; Ebers et al., 2016). Those that do focus mainly on the use of financial incentives to reduce the cost of biomass acquisition and conversion. An earlier analysis classifying 370 relevant state policies demonstrated the heavy reliance on tax incentives and technical assistance programs as preferred policy instruments, heavily focusing on the energy conversion and consumer market stages of the supply chain (Becker et al., 2011). A more recent analysis of 475 state and 19 federal policies supported earlier findings suggesting that financial instruments were the tools of choice for policy makers (Ebers et al., 2016). The study categorized policies as regulation, incentive or information instruments with more than half $(56.4 \%)$ of the identified policies labeled as incentives. States were nearly twice as likely as the federal government to adopt regulatory policies with 38 states adopting some form of a renewable portfolio standard (RPS), which establishes mandated renewable electricity production or distribution targets for utilities. 


\subsection{Social Acceptance of Woody Biomass Production}

One potential explanation for a lack of supportive woody biopower policies is the contentious nature of forest management and energy development policy. Social acceptance has been identified as one of the primary barriers to successful renewable energy projects, yet inadequate attention has been given to the topic (Wüstenhagen et al., 2007). Work by Brunson (1996) pertaining to forest management described social acceptance as "A condition that results from a judgmental process by which individuals 1) incorporate the perceived reality with its known alternatives; and 2) decide whether the 'real' condition is superior, or sufficiently similar to the most favorable alternative condition." Social acceptance of natural resource management is affected by 1) social influences and norms; 2) technical and personal knowledge;

3) spatial, temporal, and social contexts; 4) institutional and personal trust; 5) aesthetics; and 6) risk and uncertainty (Stankey \& Shindler, 2006). Initial work on the social acceptance of renewable energy looked beyond general public opposition and included political and regulatory conditions of acceptance (Carlman, 1984, pp. 339 via Wustenhagen et al., 2007). This wider scope of social acceptance for renewable energy was refined by Wüstenhagen et al. (2007) through a triangular model that included socio-political, community, and market components of acceptance.

The social acceptance of forest management has been widely studied (Long, 2009); however, very little attention has been paid to the concept in terms of 
bioenergy production (Chin et al., 2014). Neglecting the concept of social acceptance can lead to the postponement, prevention or modification of harvesting activities through litigation, increased media scrutiny, lobbying efforts, and even new legislation (Kaiser, 2006; Shindler et al., 2002). This is particularly true for harvesting operations on public lands where local and national stakeholders have used the courts as a means to prevent undesirable forest management activities (Miller, 2014). The concept of mixed use and mixed benefit has become embedded in national forest management policies, often requiring public comments on proposed forest service policies (Leach, 2006; Smith, 2012). Social acceptance has been identified as a major factor in the success of bioenergy facilities with biomass source selection being critical to the public's perspective of the project (Brohmann et al., 2007; Rösch \& Kaltschmitt, 1999; Upreti, 2004). In comparison to other renewable energy projects (e.g. solar technology), local stakeholders play a more critical role in determining social acceptance (Brohmann et al., 2007). However, recent theoretical models of bioenergy social acceptance only consider biomass producers' attitudes when evaluating the acceptance of feedstock production (Chin et al., 2014) and fail to take into account the influence of other key stakeholder groups such as the general public.

Empirical studies that explicitly focus on the social acceptance of forestbased bioenergy projects are limited to just a few focused on biomass acquisition. This small body of literature has shown that the project's scale of production facilities, perceptions of bioenergy, proximity of respondents' residence to the 
bioenergy conversion facility, and ethical considerations influenced respondents' overall acceptance of the bioenergy facility (Wuste \& Schmuck, 2013). However, previous studies on the social acceptance of intensive forest management provide insight into perceptions regarding the impact of woody energy harvesting. These studies indicate that the general public's perception of forest management activities are influenced by the number of green trees remaining after harvests (Ribe, 2006), forest age (Ribe, 2006), perceptions of depleted resources (Bliss, 2000), landownership type (Bliss, 2000; Hemström et al., 2014), knowledge of forestry practices (Bliss, 2000), and perception of the need to increase forest stocks (Hemström et al., 2014).

Previous studies that more generally focus on bioenergy attitudes provide insight into drivers of the social acceptance of forest biomass projects. Several studies have specifically focused on attitudes toward forest-based bioenergy projects. Studies have shown the following factors reduce public support for woody biomass production: operations perceived to have negative effects on forest health (Plate et al., 2010; Singer, 2013; Stidham \& Simon-Brown, 2011), intensive harvesting methods (Pires, 2011), the use of genetically modified tree species (Pires, 2011), and operations that negatively affect air quality (Plate, Monroe, \& Oxarat, 2010). However, woody bioenergy projects that are perceived to reduce the risk of wildfires and lead to job creation increase public support (Stidham \& Simon-Brown, 2011). Even so, some stakeholder groups express concerns that project developers' profit motivation would conflict with other public forest benefits and indicated that 
biomass produced from public forestlands may meet significant resistance (Stidham \& Simon-Brown, 2011). These groups often view the impacts of forest bioenergy production very differently (Dwivedi \& Alavalapati, 2009). Factors such as level of familiarity with bioenergy (Halder et al., 2012; Wegener \& Kelly, 2008); income (Ulmer et al., 2004); age (Ulmer et al., 2004); rural residency (Halder et al., 2012; Ulmer et al., 2004); and gender (Halder et al., 2012) influence attitudes toward bioenergy production.

\subsection{Forest-based Ecosystem Services}

Ecosystem services are defined as the benefits that humans receive from ecosystems (Millennium Ecosystem Assessment, 2005). Ecosystem service theory was developed out of the need to help natural resource decision makers evaluate tradeoffs between various land use scenarios. Daily (1997) argued that decision-making tools like cost-benefit analysis, which rely upon economic inputs, have driven much of human behavior and decision making. Over the past 50 years, the totality of humankind's decision have placed increasing pressure on ecosystems, threatening many of the world's vital ecological services that are necessary for humanity's very existence (Millennium Ecosystem Assessment, 2005). A means to quantify and correct the chronic undervaluation of ecosystem benefits to human well-being is necessary to counterbalance the economic value derived from human activities that degrade much of the world's ecosystems (Daily, 1997). 
Forests ecosystems provide numerous ecosystem services both at local and global scales. Forests help to: protect soils and retain moisture; store and cycle nutrients in soil; mitigate the spread of pests and diseases; regulate water quality and quantity; prevent drought and flooding; provide energy; provide climate regulation through rainfall regulation and the albedo effect; and sequester carbon in trees and soils (Myers, 1997). In addition, forests provide habitat for species (both plant and animal) that play an integral role in the human food system, the production of raw \& Climate Change, 2014 \#715" [ U.K. Department of Energy \& Climate Change, 2014a

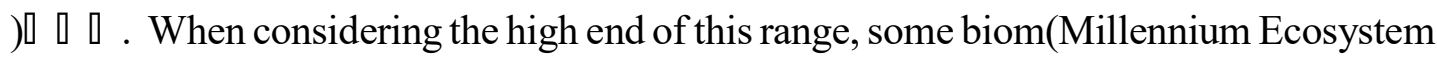
Assessment, 2005).

Energy wood harvesting practices, through the removal of stumps, large and fine deadwood, and small-diameter trees, affect forest structure even more so than traditional whole-tree harvesting practices generally seen in timber and pulp operations (Berger et al., 2013). Enhanced demand for woody biomass may affect traditional forest management practices in the following ways: 1) increased harvesting on previously unmanaged or previously poorly managed forestland to access small diameter species; 2) enhanced removal of residue materials from forest floors after harvesting operations; and 3) expanded use of short-rotation tree species like hybrid poplar and willow on abandoned agricultural or forage land using agricultural practices such as shorter rotation times and increased use of fertilizers, pesticides and herbicides (Janowiak \& Webster, 2010). These differences from conventional timber management practices are likely imperceptible to the general 
public, although public officials, highly attentive environmental groups and forest owners involved in timber production would likely be aware of these differences.

Despite the numerous potential benefits of forest-based bioenergy (e.g. climate change mitigation, rural economic development, wildfire risk mitigation, forest health improvements, etc.), intensive forest biomass production has the potential to adversely affect many other forest-based ecosystems services. For example, research shows that the use of wood for energy production has the potential to negatively affect forest soil and water quality, long-term site productivity, biodiversity, and net greenhouse gas (GHG) sequestration (Lattimore et al., 2009). A North American study by Berger et al. (2013) compared the use of whole-tree harvesting for biomass production to conventional harvesting methods. The study found that harvesting methods most likely used for forest biomass production would reduce the amount of harvesting residues within the harvest region, negatively impacting carbon stocks and soil nutrient levels. The study also found that harvesting for biomass will have both positive and negative effects on forest biodiversity depending on each species' requirements. An analysis of intensive forest bioenergy harvests conducted in the Amazon Basin revealed a decline in forest-based ecosystem services such as carbon storage, river flows, regulation of regional climate, and limiting the amelioration of infections diseases for nearby human populations (Foley et al., 2007). The social impacts of woody biomass production are much less well understood. According to a comprehensive literature review of forest-biomass sustainability studies by Cambero and Sowlati (2014), no 
dedicated social sustainability assessment studies have been completed because of the difficult nature of quantifying social effects of bioenergy production. However, work specifically on biofuels has shown that biomass production can negatively affect numerous ecosystem services related to food, air quality, water availability and quality, erosion control and cultural services (e.g. spiritual, aesthetic, education, recreational, and biodiversity services) (Flaspohler et al., 2008; Gasparatos et al., 2011; Phalan, 2009; Stromberg et al., 2010).

\subsection{Social Values of Ecosystem Services}

Incorporating social values into natural resource management helps to reduce conflict stemming from competing multiple-use priorities of forested landscapes (McIntyre et al., 2008). A growing literature has focused on understanding how people value and prioritize ecosystem services to help key decision makers craft land use polices. This allows input from affected stakeholder groups to identify priority ecosystem services and provide feedback on management options (Seppelt et al., 2011). To date, most of the scholarship on ecosystem service values has focused on assessing preferences based on service type (e.g. provisioning, regulating, cultural, and supporting). In addition, studies have evaluated the differences between perceptions of benefits at different scales (e.g. personal benefits and societal benefits) and public views on levels of and threats to service supplies. This work is important to overall natural resource management, but to my knowledge it has not been connected to studies on biomass production. Doing so would provide a better 
understanding of stakeholders' perceptions of biomass production's effects on critical ecosystem services.

Sociocultural preferences toward the importance and management of ecosystem services will differ across stakeholder groups because values, beliefs, and attitudes are diverse (Chan et al., 2012). Numerous studies have highlighted the fact that stakeholder groups varying in age, population density, and education often differ regarding ecosystem service preferences (Agbenyega et al., 2009; Clement \& Cheng, 2011; Kraxner et al., 2009; Martín-López et al., 2012; Oteros-Rozas et al., 2014; Sodhi et al., 2010). These studies showed that age, gender, rural/urban residency, employment, proximity to ecosystems, and direct use of ecosystems affect ecosystem service values. Other studies have focused on the dynamic between values and levels (individual, community or societal) of benefits. A study by Hauru et al. (2015) evaluated respondents' preferences for services based on individual and societal benefit orientation but found very little differences when comparing these two levels. However, Oteros-Rozas et al. (2014) found that respondents viewed ecosystem services differently when considering personal and societal well-being. Their study found that respondents tended to place a higher value on cultural services when considering their importance to personal well-being.

\subsection{Woody Biomass Sustainability Certification}

Market-based, self-regulating certification schemes have emerged to address negative environmental, social, and economic effects of industries when traditional, 
state-centric policy mechanisms fall short (Cashore et al., 2007). Certification schemes offer a market-based strategy that encourages producers of a given commodity to adhere to voluntary standards in return for formal recognition of meeting said requirements through recognizable labeling. Certification schemes have become a popular strategy for addressing sustainability challenges of both sustainable forest management (SFM) and bioenergy feedstock production (Cashore et al., 2007).

The development of bioenergy certification schemes has been driven by concerns of climate change, energy security, and food insecurity from large-scale land use conversion from food crops to biofuel crops. Programs are designed to cover various energy forms, including liquid transportation fuels and the use of biomaterials for electricity and heat production (Gan and Cashore, 2013). Organizations such as the Roundtable on Sustainable Biomaterials (RSB), International Sustainability \& Carbon Certification (ISCC), Round Table on Responsible Soy (RPS), and Roundtable on Sustainable Palm Oil (RSPO) have created certification programs that used market-based strategy to encourage the sustainable production of various biofuel feedstocks (Moser et al., 2014), and RSB and ISCC are considered to be the most comprehensive in addressing sustainability criteria (Gan \& Cashore, 2013).

SFM scheme development has been driven by the ecological, economic, and social consequences of large-scale deforestation, particularly in developing countries (Scarlat \& Dallemand, 2011). While SFM schemes often fail to directly address 
these bioenergy specific criteria, many of the sustainability criteria required for bioenergy, such as climate change mitigation, can be indirectly addressed through SFM requirements like afforestation (Stupak et al., 2011). However, the increasing use of forest biomaterials for bioenergy production presents places pressure on SFM certifications to address the duality of both bioenergy and traditional forest management sustainability challenges (Gan \& Cashore, 2013).

The dominant sustainable forest management (SFM) programs in the U.S. are the Forest Stewardship Council (FSC) and the Sustainable Forestry Initiative (SFI). Collectively, the two programs certify nearly 40 million hectares in the U.S. SFI is the largest single source forestry certification program in the world and certifies approximately 24 million hectares in the U.S. It is one of two U.S.-endorsed members of the international meta-standard certification organization, the Program for the Endorsement of Forest Certification (PEFC) schemes (the other member being the American Tree Farm System). The FSC was established in 1993 following the Earth Summit in Rio de Janeiro that focused more on the issue of global climate change and failed to adequately address the increasing deforestation. Today, FSC operations are found in more than 80 countries, with nearly than 14.3 million hectares certified in the U.S. (Forest Stewardship Council, 2015). Forestry certification schemes have been criticized for failing to achieve target price premiums and market access (Bond et al., 2014; Overdevest \& Rickenbach, 2006), high costs and complexities of participation (Auld et al., 2008; Humphries \& Kainer, 
2006), limited effectiveness at preventing illegal logging (Schepers, 2010), and limited effectiveness at protecting forest biodiversity (Schepers, 2010).

\subsection{Overview of the Research Chapters}

My dissertation focuses on two vexing questions pertaining to energy produced from forest biomaterials: First, despite its potential as a dispatchable source for renewable energy and economic outlet for the wood-products industry, why have policy makers failed to develop a supportive policy framework for the forest biopower industry? Second, how can the industry become more socially acceptable as the use of forest biomaterials for energy production increases?

The following chapter explores the evolution of the Wisconsin energy renewable policy mix, which has shaped woody biopower development over the past two decades. The third chapter presents findings from a household survey in Tomahawk, WI, which analyzes the relationship between public perceptions, ecosystem service values and support for local woody biomass production for electric power. The fourth chapter assesses the effectiveness of SFM certification standards to ensure sustainable production of woody biomass for heat and power production. The final chapter discusses the interconnectivity between each of these chapters and their overall relevancy to public policy. The last chapter also discusses limitations of the research and opportunities for future research. Each of the following three research chapters have been, or will be, submitted to peer-review journals. A brief overview of each research chapter is provided below. 


\section{Chapter 2 Overview}

Chapter Two, titled Dismantling through Dilution: Wisconsin's Renewable Portfolio Standard (RPS) \& Wavering Support for Woody Biopower Production, explores the interactions between shifting goals, actors and institutions in influencing incentives that shape today's policy mix for woody biopower production in Wisconsin. Using a historical institutionalist framework and data from the Wisconsin Ethics

Commission, I examine more than two decades (1993-2015) of Wisconsin energy and forest products policy to understand changes in the policy mix's capacity to leverage forest biopower production. The study's results reveal that Wisconsin's RPS and overall policy mix experienced early periods of policy congruency; however, the recent call for cost effective and affordable energy has resulted in a unique form of policy dismantling I refer to as policy "dilution". The dearth of supportive policy appears to be a result of the industry's failure to develop representative coalitions at the state level to protect and build upon favorable policy positions established after the expansion of the RPS in 2009.

\section{Chapter 3 Overview}

A growing literature focuses on measuring the social value of ecosystem services, alongside traditional economic valuations, to inform natural resource management decisions. However, very few studies have explored the role of ecosystem service values in the context of the general public's support for natural resource management 
decisions. This leaves open the possibility that policy makers and resource managers are relying on criteria that have negligible influence on the public's decision-making process.

In Chapter Three, titled Deciphering Support for Woody Biomass Production for Electric Power Using an Ecosystem Service Framework, I use data from a general household survey of Tomahawk, Wisconsin residents to evaluate support for woody biomass production for power generation. The community of Tomahawk was selected because it is a rural community within the expected harvesting zone of a new combined-heat and power woody biopower facility located in Rothschild, WI, and the area's forestland already supplies the region's pulp and timber industry. These characteristics make Tomahawk similar to other communities experiencing woody biomass harvesting development. By focusing on Tomahawk, WI, this work utilizes a hypothesis-generating case study approach, which inhibits statistical generalizability to only households within the study area. However, the case study's results can be used to empirically identify potential relationships between households' support for woody biomass production and other explanatory and control variables likely to be found in similar forest biomass production communities. It also contributes toward theory building pertaining to the social sustainability of the industry (Lijphart, 1971). These results can then be used in subsequent case studies in order to test the theories generated from this work.

Results from the Tomahawk study show respondents in biomass producing communities are more supportive of biomass sources such as forestry residues and 
forestry thinnings than dedicated energy wood harvesting operations. In addition, the results indicate that using an ecosystem service approach can help explain differences in support between these respondents and provide insight into socially acceptable forms of biomass harvesting operations. These results demonstrate that consideration of public ecosystem service values during policy and project development can help shape socially acceptable forms of woody biomass production, and potentially other forms of land use decisions embodying complex social, economic and environmental tradeoffs.

\section{Chapter 4 Overview}

The threat of climate change and depletion of fossil fuels is pushing many countries to aggressively pursue renewable energy sources for power production. This has led some countries, like the United Kingdom, to develop national policies incentivizing the import of woody biomaterials for heat and power production. Concerns that global biomass demand would lead to unstainable forest management practices have driven some policy makers to seek out third party sustainability verification of their imports. This study, titled An Evaluation of the U.K. 's use of SFM Standards to Procure Solid Woody Biomass for Electricity Generation Using Sustainable Bioenergy Criteria, evaluates the U.K.'s use of sustainable forest management certification programs as a tool to ensure the sourcing of sustainable woody biomass imports from countries such as the United States. Using criteria found in the scholarly literature for sustainable bioenergy feedstock production, I assess the 
effectiveness of these schemes to ensure sustainable bioenergy materials. I argue that the definition of sustainably sourced biomaterials, which are cultivated because of their climate change mitigation potential, requires a broader set of indicators than what the traditional sustainable forest management programs traditionally consider. The sustainability of U.K. woody biomass imports for electricity would be improved by coupling sustainable forest management programs with a bioenergy sustainability scheme such as the one designed by the Roundtable on Sustainable Biomaterials. 


\subsection{References}

Abrams, J., Becker, D., Kudrna, J., \& Moseley, C. (2017). Does policy matter? The role of policy systems in forest bioenergy development in the United States. Forest Policy and Economics, 75, 41-48.

Agbenyega, O., Burgess, P. J., Cook, M., \& Morris, J. (2009). Application of an ecosystem function framework to perceptions of community woodlands. Land Use Policy, 26(3), 551-557.

Aguilar, F. X. (2015). Wood energy in developed economies: An overlooked renewable. Resources for the Future, (188), 20-27.

Aguilar, F. X., \& Saunders, A. (2010). Policy instruments promoting wood-to-energy uses in the continental United States. Journal of Forestry, 108(3), 132-140.

Auld, G., Gulbrandsen, L. H., \& McDermott, C. L. (2008). Certification schemes and the impacts on forests and forestry. Annual Review of Environment and Resources, 33, 187-211.

Barnett, B. (2016). An evaluation of the UK's use of SFM standards to procure solid woody biomass for electricity generation using sustainable bioenergy criteria. Biofuels, 7(1), 1-11.

Becker, D., Moseley, C., \& Lee, C. (2011). A supply chain analysis framework for assessing state-level forest biomass utilization policies in the United States. Biomass and Bioenergy, 35(4), 1429-1439.

Berger, A. L., Palik, B., D'Amato, A. W., Fraver, S., Bradford, J. B., Nislow, K., . . . Brooks, R. T. (2013). Ecological impacts of energy-wood harvests: Lessons 
from whole-tree harvesting and natural disturbance. Journal of Forestry, $111(2), 139-153$.

Bliss, J. C. (2000). Public perceptions of clearcutting. Journal of Forestry, 98(12), 49.

Bond, B., Lyon, S., Munsell, J., Barrett, S., \& Gagnon, J. (2014). Perceptions of Virginia's primary forest products manufacturers regarding forest certification. Forest Products Journal, 64(7), 242-249.

Boström, M. (2012). A missing pillar? Challenges in theorizing and practicing social sustainability: introduction to the special issue. Sustainability: Science, Practice, \& Policy, 8(1), 3-14.

Brohmann, B., Feenstra, Y., Heiskanen, E., Hodson, M., Mourik, R., Prasad, G., \& Raven, R. (2007). Factors influencing the societal acceptance of new, renewable and energy efficiency technologies: Meta-analysis of recent European projects. Paper presented at the European roundtable for sustainable consumption and production, Basel, Switzerland.

Bronfman, N. C., Jiménez, R. B., Arévalo, P. C., \& Cifuentes, L. A. (2012). Understanding social acceptance of electricity generation sources. Energy Policy, 46, 246-252.

Brown, M. A., \& Sovacool, B. K. (2011). Climate change and global energy security: technology and policy options. Cambridge, MA: MIT Press.

Brunson, M. W. (1996). A definition of" social acceptability" in ecosystem management. (0887-4840). Keslo, Washington. 
Cambero, C., \& Sowlati, T. (2014). Assessment and optimization of forest biomass supply chains from economic, social and environmental perspectives-A review of literature. Renewable and Sustainable Energy Reviews, 36, 62-73.

Carlman, I. (1984). The views of politicians and decision-makers on planning for the use of wind power in Sweden. Paper presented at the European Wind Energy Conference, Hamburg.

Cashore, B., Egan, E., Auld, G., \& Newsom, D. (2007). Revising theories of nonstate market-driven (NSMD) governance: Lessons from the Finnish forest certification experience. Global Environmental Politics, 7(1), 1-44.

Chan, K. M. A., Satterfield, T., \& Goldstein, J. (2012). Rethinking ecosystem services to better address and navigate cultural values. Ecological Economics, 74, 8-18. doi: http://dx.doi.org/10.1016/j.ecolecon.2011.11.011

Chin, H.-C., Choong, W.-W., Alwi, S. R. W., \& Mohammed, A. H. (2014). Issues of social acceptance on biofuel development. Journal of Cleaner Production, $71,30-39$

Clement, J. M., \& Cheng, A. S. (2011). Using analyses of public value orientations, attitudes and preferences to inform national forest planning in Colorado and Wyoming. Applied Geography, 31(2), 393-400.

Daily, G. (1997). Nature's services: societal dependence on natural ecosystems. Washington, D.C.: Island Press. 
Dwivedi, P., \& Alavalapati, J. R. (2009). Stakeholders' perceptions on forest biomass-based bioenergy development in the southern US. Energy Policy, 37(5), 1999-2007.

Ebers, A., Malmsheimer, R. W., Volk, T. A., \& Newman, D. H. (2016). Inventory and classification of United States federal and state forest biomass electricity and heat policies. Biomass and Bioenergy, 84, 67-75.

Flaspohler, D. J., Froese, R., \& Webster, C. (2008). Bioenergy, biomass and biodiversity. In B. D. Solomon \& V. A. Luzadis (Eds.), Renewable Energy from Forest Resources in the United States (pp. 133-162). New York, NY: Routlege.

Foley, J. A., Asner, G. P., Costa, M. H., Coe, M. T., DeFries, R., Gibbs, H. K., . . Ramankutty, N. (2007). Amazonia revealed: forest degradation and loss of ecosystem goods and services in the Amazon Basin. Frontiers in Ecology and the Environment, 5(1), 25-32.

Forest Stewardship Council. (2015). Global FSC certificates: type and distribution. from https://ic.fsc.org/facts-figures.19.htm

Gan, J., \& Cashore, B. (2013). Opportunities and challenges for integrating bioenergy into sustainable forest management certification programs. Journal of Forestry, 111(1), 11-16.

Gasparatos, A., Stromberg, P., \& Takeuchi, K. (2011). Biofuels, ecosystem services and human wellbeing: Putting biofuels in the ecosystem services narrative. 
Agriculture, Ecosystems \& Environment, 142(3-4), 111-128. doi:

http://dx.doi.org/10.1016/j.agee.2011.04.020

Halder, P., Prokop, P., Chang, C.-Y., Usak, M., Pietarinen, J., Havu-Nuutinen, S., . . . Cakir, M. (2012). International survey on bioenergy knowledge, perceptions, and attitudes among young citizens. BioEnergy Research, 5(1), $247-261$.

Hauru, K., Eskelinen, H., Yli-Pelkonen, V., Kuoppamäki, K., \& Setälä, H. (2015). Residents' perceived benefits and the use of urban nearby forests. International Journal of Applied Forestry, 2(1), 1-23.

Hemström, K., Mahapatra, K., \& Gustavsson, L. (2014). Public Perceptions and Acceptance of Intensive Forestry in Sweden. Ambio, 43(2), 196-206.

Holland, R., Eigenbrod, F., Muggeridge, A., Brown, G., Clarke, D., \& Taylor, G. (2015). A synthesis of the ecosystem services impact of second generation bioenergy crop production. Renewable and Sustainable Energy Reviews, 46, $30-40$.

Humphries, S. S., \& Kainer, K. A. (2006). Local perceptions of forest certification for community-based enterprises. Forest Ecology and Management, 235(13), 30-43.

IPCC. (2007). Summary for policymakers, In: Climate Change: 2007: The Physical Science Basis. Contribution of Working Group I to the Fourth Assessment Report for the Intergovernmental Panel on Climate Change. Cambridge, United Kingdom. 
Janowiak, M. K., \& Webster, C. R. (2010). Promoting ecological sustainability in woody biomass harvesting. Journal of Forestry, 108(1), 16-23.

Kaiser, B. A. (2006). The national environmental policy act's influence on USDA forest service decision-making, 1974-1996. Journal of Forest Economics, $12(2), 109-130$.

Kraxner, F., Yang, J., \& Yamagata, Y. (2009). Attitudes towards forest, biomass and certification-A case study approach to integrate public opinion in Japan. Bioresource Technology, 100(17), 4058-4061.

Lackner, K. S., \& Sachs, J. (2005). A robust strategy for sustainable energy. Brookings Papers on Economic Activity, 2005(2), 215-284.

Lantiainen, S. M., Song, N., \& Aguilar, F. X. (2014). Public policy promoting wood energy in the EU and US. In F. X. Aguilar (Ed.), Wood Energy in Developed Economies: Resource Management, Economics and Policy (pp. 189-222).

Lattimore, B., Smith, C. T., Titus, B. D., Stupak, I., \& Egnell, G. (2009). Environmental factors in woodfuel production: Opportunities, risks, and criteria and indicators for sustainable practices. Biomass and Bioenergy, 33(10), 1321-1342. doi: http://dx.doi.org/10.1016/j.biombioe.2009.06.005

Lauri, P., Havlík, P., Kindermann, G., Forsell, N., Böttcher, H., \& Obersteiner, M. (2014). Woody biomass energy potential in 2050. Energy Policy, 66, 19-31.

Leach, W. D. (2006). Public involvement in USDA Forest Service policymaking: a literature review. Journal of Forestry, 104(1), 43-49. 
Lijphart, A. (1971). Comparative politics and the comparative method. American Political Science Review, 65(3), 682-693.

Long, J. N. (2009). Emulating natural disturbance regimes as a basis for forest management: a North American view. Forest Ecology and Management, 257(9), 1868-1873.

Luzadis, V. A., Volk, T. A., \& Buchholz, T. S. (2008). Using a systems approach to improve bioenergy sustainability assessment. In B. D. Solomon \& V. A. Luzadis (Eds.), Renewable Energy from Forest Resources in the United States. New York, NY: Routledge, 196-210.

Magis, K., \& Shinn, C. (2009). Emergent principles of social sustainability. In J. Dillard, V. Dujon \& M. C. King (Eds.), Understanding the social dimension of sustainability (pp. 15-44). New York, NY: Routledge.

Martín-López, B., Iniesta-Arandia, I., García-Llorente, M., Palomo, I., CasadoArzuaga, I., Del Amo, D. G., ... Willaarts, B. (2012). Uncovering ecosystem service bundles through social preferences. PloS One, 7(6), e38970.

McIntyre, N., Moore, J., \& Yuan, M. (2008). A place-based, values-centered approach to managing recreation on Canadian crown lands. Society and Natural Resources, 21(8), 657-670.

Millennium Ecosystem Assessment. (2005). Ecosystems and human well-being biodiversity synthesis. Washington, DC: World Resources Institute.

Miller, G. W. (2014). The Monongahela clearcutting controversy: Scientists and land managers develop an alternative practice on the Fernow Experimental Forest 
USDA Forest Service Experimental Forests and Ranges (pp. 173-199): Springer.

Moser, C., Hildebrandt, T., \& Bailis, R. (2014). International sustainability standards and certification. In B. D. Solomon \& R. Bailis (Eds.), Sustainable development of biofuels in Latin America and the Caribbean (pp. 27-69). New York: Springer.

Myers, N. (1997). The world's forests and their ecosystem services. In G. C. Daily (Ed.), Nature's Services: societal dependence on natural ecosystems (pp. 215-235). Washington, DC: Island Press.

New York State Energy Research \& Development Authority. (2014). New York State Renewable Portfolio Standard: Biomass Power Guide. Retrieved from https://www.nyserda.ny.gov/-/media/Files/EDPPP/Energy-andEnvironmental-Markets/RPS/RPS-Documents/NYS-RPS-biomassguidebook.pdf.

Oteros-Rozas, E., Martín-López, B., González, J. A., Plieninger, T., López, C. A., \& Montes, C. (2014). Socio-cultural valuation of ecosystem services in a transhumance social-ecological network. Regional Environmental Change, 14(4), 1269-1289.

Overdevest, C., \& Rickenbach, M. G. (2006). Forest certification and institutional governance: an empirical study of forest stewardship council certificate holders in the United States. Forest Policy and Economics, 9(1), 93-102. 
Phalan, B. (2009). The social and environmental impacts of biofuels in Asia: An overview. Applied Energy, 86, Supplement 1(0), S21-S29. doi: http://dx.doi.org/10.1016/j.apenergy.2009.04.046

Pires, S. T. (2011). Social perceptions of the biofuel industry in the southeastern US. Master of Science thesis, North Carolina State University.

Plate, R., Monroe, M., \& Oxarart, A. (2010). Public perceptions of using woody biomass as a renewable energy source. Journal of Extension, 48(3), 1-15.

Reddy, A., Williams, R., \& Johansson, T. (1997). Energy after Rio: Prospects and challenges. United Nations Development Program. New York: United Nations Publications.

Ribe, R. G. (2006). Perceptions of forestry alternatives in the US Pacific Northwest: Information effects and acceptability distribution analysis. Journal of Environmental Psychology, 26(2), 100-115.

Rösch, C., \& Kaltschmitt, M. (1999). Energy from biomass-do non-technical barriers prevent an increased use? Biomass and Bioenergy, 16(5), 347-356.

Scarlat, N., \& Dallemand, J.-F. (2011). Recent developments of biofuels/bioenergy sustainability certification: A global overview. Energy Policy, 39(3), 16301646.

Schepers, D. H. (2010). Challenges to legitimacy at the Forest Stewardship Council. Journal of Business Ethics, 92(2), 279-290. 
Seppelt, R., Dormann, C. F., Eppink, F. V., Lautenbach, S., \& Schmidt, S. (2011). A quantitative review of ecosystem service studies: Approaches, shortcomings and the road ahead. Journal of Applied Ecology, 48(3), 630-636.

Shindler, B. A., Brunson, M., \& Stankey, G. H. (2002). Social acceptability of forest conditions and management practices: a problem analysis. General Technical Report-Pacific Northwest Research Station, USDA Forest Service(PNWGTR-537).

Singer, C. (2013). Stakeholder Attitudes Toward Forest-Residual Based Biofuels in Washington State. Doctoral dissertation, University of Washington.

Smith, J. W. (2012). Barriers and bridges to US Forest Service-community relationships: Results from two pilot tests of a rapid social capital assessment protocol. Forests, 3(4), 1157-1179.

Sodhi, N. S., Lee, T. M., Sekercioglu, C. H., Webb, E. L., Prawiradilaga, D. M., Lohman, D. J., . . Ehrlich, P. R. (2010). Local people value environmental services provided by forested parks. Biodiversity and Conservation, 19(4), 1175-1188.

Stankey, G. H., \& Shindler, B. (2006). Formation of social acceptability judgments and their implications for management of rare and little-known species. Conservation Biology, 20(1), 28-37.

State of Maine. (2012). Comments on Proposed Regulation 225 CMR 14.00.: Retrieved from http://www.mass.gov/eea/docs/doer/renewables/biomass/rps- 
$\underline{\text { regulation-comments/state-of-maine-patricia-aho-william-beardsley-kenneth- }}$ fletcher.pdf. .

Stidham, M., \& Simon-Brown, V. (2011). Stakeholder perspectives on converting forest biomass to energy in Oregon, USA. Biomass and Bioenergy, 35(1), 203-213. doi: http://dx.doi.org/10.1016/j.biombioe.2010.08.014

Stromberg, P. M., Gasparatos, A., Lee, J. S. H., Garcia-Ulloa, J., Koh, L. P., \& Takeuchi, K. (2010). Impact of liquid biofuels on ecosystem services and biodiversity (I. o. A. Studies, Trans.). Tokyo: United Nations University.

Stupak, I., Lattimore, B., Titus, B. D., \& Smith, C. T. (2011). Criteria and indicators for sustainable forest fuel production and harvesting: a review of current standards for sustainable forest management. Biomass and Bioenergy, 35(8), $3287-3308$.

U.K. Department of Energy \& Climate Change. (2014). Timber standard for heat \& electricity: Woodfuel used under the Renewable Heat Incentive and Renewables Obligation. (Report URN 14D/025).

U.S. Department of Energy. (2018a). Business Energy Investment Tax Credit (ITC). Retrieved July 15, 2018, from https://www.energy.gov/savings/business$\underline{\text { energy-investment-tax-credit-itc }}$

U.S. Department of Energy. (2018b). Renewable Electricity Production Tax Credit (PTC). Retrieved July 15, 2018, from https://www.energy.gov/savings/renewable-electricity-production-tax-creditptc 
U.S. Energy Information Administration. (2016). International Energy Outlook 2016: With Projections to 2040. Washington, D.C.: Government Printing Office.

Ulmer, J. D., Huhnke, R. L., Bellmer, D. D., \& Dwayne Cartmell, D. (2004). Acceptance of ethanol-blended gasoline in Oklahoma. Biomass and Bioenergy, 27(5), 437-444.

Upreti, B. R. (2004). Conflict over biomass energy development in the United Kingdom: some observations and lessons from England and Wales. Energy Policy, 32(6), 785-800. doi: http://dx.doi.org/10.1016/S0301-4215(02)00342$\underline{7}$

Wegener, D., \& Kelly, J. (2008). Social psychological dimensions of bioenergy development and public acceptance. BioEnergy Research, 1(2), 107-117. doi: $10.1007 / \mathrm{s} 12155-008-9012-\mathrm{Z}$

Wüste, A., \& Schmuck, P. (2013). Social acceptance of bioenergy use and the success factors of communal bioenergy projects. In H. Ruppert, M. Kappas \& J. Ibendorf (Eds.), Sustainable Bioenergy Production-An Integrated Approach (pp. 293-318). London: Springer.

Wüstenhagen, R., Wolsink, M., \& Bürer, M. J. (2007). Social acceptance of renewable energy innovation: An introduction to the concept. Energy Policy, $35(5), 2683-2691$. 


\section{Chapter 2: Dismantling through Dilution: Wisconsin's Renewable Portfolio Standard (RPS) \& Wavering Support for Woody Biopower Production $^{1}$}

This study explores the nexus between changing goals, actors and institutions in shaping incentives that form today's policy mix for woody biopower production in Wisconsin. Using a historical institutionalist framework and data from the Wisconsin Ethics Commission, I examine more than two decades (1993-2015) of Wisconsin energy and forest products policy to understand changes in the policy mix's capacity to produce forest biopower. The study's results reveal that Wisconsin's RPS and overall policy mix experienced early periods of policy congruency; however, the recent call for cost effective and affordable energy has resulted in a unique form of policy dismantling that I refer to as policy "dilution". The dearth of supportive policy appears to be a result of the industry's failure to develop representation coalitions at the state level to protect and build upon favorable policy positions established after the initial expansion of the RPS in 2009.

\footnotetext{
${ }^{1}$ The material contained in this chapter is in preparation for submission to the Journal of Environmental Policy and Planning.
} 


\subsection{Introduction}

Heat and power produced from woody biomass (e.g. low value timber, forest residues, mill residues, etc.) represent one of the largest sources of potential renewable energy in developed countries (Aguilar, 2015). In the United States, the combination of federal incentives under the Public Utility Regulatory Policies Act of 1978 and state policy initiatives such as renewable portfolio standards (RPS) have increased the use of woody biomass by utilities and large industrial power consumers seeking to transition away from coal (Aguilar, 2015). Policy frameworks supporting the use of woody biomass to produce electricity, or woody biopower, are driven by goals to mitigate climate change while fostering economic growth and energy independence (F. X. Aguilar \& A. Saunders, 2010). However, states rarely develop policies intended to directly support woody biopower production (F. Aguilar \& A. Saunders, 2010).

In the United States, policymakers at state and federal levels have pursued a patchwork of policies intended to stimulate and support woody bioenergy industry development (Becker et al., 2011; Ebers et al., 2016). Using varying taxonomies to identify and categorize relevant policies, scholars have demonstrated few policies directly target woody biopower production in favor of more general renewable power production goals despite the industry's potential to achieve economic, climate change mitigation, and environmental goals. Aguilar \& Saunders' (2010) analysis indicates that the clear majority of U.S. state policies influencing woody bioenergy development are indirect in nature, meaning the policies generally promote multiple 
renewable generation technologies (e.g. wind, solar, geothermal) instead of directly focusing on woody bioenergy production specifically. At the time of their study, Aguilar \& Saunders' (2010) work indicated a total of 272 U.S. state indirect policy instruments influenced woody bioenergy development. These included polices with instruments such as RPS requirements, tax incentives, grants, technical assistance programs, production subsidies, and start-up cost share programs. At the same time, only five policy instruments uniquely addressed the promotion of woody biomass use for energy production all of which were financial incentives (e.g. investment tax credits, production subsidies, etc.). Other studies show that the adoption of direct woody biopower supportive policies can dramatically vary geographically even when comparing forest-rich regions within the United States (Becker et al., 2011; Ebers et al., 2016; Lantiainen et al., 2014), with states like Oregon aggressively pursuing supportive policies when compared to Midwest states like Wisconsin. Often, the resulting policy mix has been incoherent due to incompatible energy, biomass production and environmental protection goals (Abrams et al., 2017).

Over the past twenty years, Wisconsin's woody biopower policy mix, or its strategic policy goals, actors, and instruments has evolved during dramatic economic and political sea changes (David, 2017; Rogge \& Reichardt, 2016). Due to the state's substantial forest resources and abundance of low cost biomaterial generated by the forest products industry, the state has identified wood-based energy as a valuable economic development asset (Radloff et al., 2012). However, it wasn't until the 1990s that the state began to develop policies to support woody biopower 
production. In response to the state's lack of fossil fuel resources, natural gas price volatility and grid instability, Wisconsin legislators passed the 1993 Energy Priorities Act and 1997 Electric Reliability Act, which prioritized renewable sources over fossil fuels for electricity production and created a mandate for woody biopower production. However, the keystone of Wisconsin's woody biopower policy mix has been the state's 1999 RPS. The RPS created a market for electricity production from renewable sources such as woody biomass and eventually culminated in a goal of $10 \%$ of retail electric sales from qualified renewable resources by 2015 . Yet besides a $10 \%$ tax credit for biomass harvesting equipment, the state has made little effort to develop policies to support woody biopower production.

In this context, the purpose of this chapter is to address the following research question: Why have policymakers in Wisconsin failed to develop supportive woody biopower power policies despite the industry's potential to meet economic development and climate change mitigation goals? Using a historical institutionalist (HI) framework and data from the Wisconsin Ethics Commission, I examine more than two decades (1993-2015) of Wisconsin energy and forest products policy to understand changes in the policy mix's capacity to leverage forest biopower production. My analysis shows that Wisconsin's renewable power policy mix can be broken down into four separate stages of changing policy goal, instruments and actors: 1) from 1993 and 1998 when the state made a series of decisions leveraging renewable energy resources to enhance electric reliability, 2) from 1999 and 2004, which heavily focused on climate change and the establishment of the state's RPS; 3 ) 
from 2005-2010, which experienced smart policy design that helped to further enhance the RPS and support the state's woody biopower industry; and 4) from 2011 to the present when the RPS was diluted through the pursuit of cost effective renewable energy sources and economic development.

My findings reveal that Wisconsin's RPS and overall policy mix experienced early periods of policy congruency; however, the recent call for cost effective and affordable energy has resulted in a unique form of policy dismantling I refer to as policy "dilution". The dearth of supportive policy appears to be a result of the industry's failure to develop representation coalitions at the state level to protect and build upon favorable policy positions established after the initial expansion of the RPS in 2009.

The remainder of this paper will review the legislative history that influenced the use of woody biomass for electricity production in the State of Wisconsin. What follows is 1) a brief review of the key HI concepts relevant to this study, 2) a brief overview of the state's woody biopower power industry; 3) a review of the primary policies enacted influencing the industry; and 4) a discussion of how these endogenous factors support or contradict key theoretical tenants found in the HI literature. 


\subsection{Literature Review}

\subsubsection{Using Historical Institutionalism to Understand Woody Biopower Policy Change}

The woody biopower policy mix, along with the overall electricity policy mix, is highly complex and unique when compared to other policy sectors. Like Wellstead et al.'s (2016) discussion of reclamation policy in Alberta's oil sands sector, decisions related to electricity production involve extremely large capital investment that lock-in the industry and its stakeholders to long pay-back periods. Electricity generation facilities and transmission projects can have a useful lifespan of more than 60 years. This makes any decision to invest or incentivize power generation critically important with long lasting implications for multiple decades. Similarly, the decision to use woody biomass has the potential to have long-run impacts on forest health, greenhouse gas sequestration capacity of landscapes, and other forestbased industries (Goerndt et al., 2014). In addition, the sector involves a plethora of actors because converting wood to usable energy requires numerous processes and often spans large geographic regions and economic sectors (Luzadis et al., 2008). Actors play a critical role in institutional change as they have the capacity to reinforce existing ideas and norms to strengthen existing institutions or introduce new ideas and values resulting in change (Beland, 2007). Actors may include local, state, regional, and federal agencies, environmental groups, the customers that consume power generated from local utilities, other non-local consumer and utilities. The decision to use woody biomass broadens this policy network of forest owners 
and other land managers, stakeholders in other forest-based industries, forest recreational enthusiasts, and more. This introduces new ideas and values into the political system.

This combination of a wide range of actors and the power of decisions to reverberate over long time horizons make the use of $\mathrm{HI}$ ideal for the study of Wisconsin's woody biopower policy mix. HI can be used to analyze and explain how institutions and processes impact policy decisions and outcomes with special attention paid to issues like timing and context (Pierson \& Skocpol, 2002; Steinmo, 2014). At the center of HI, along with other variants of Institutionalist theory, are institutions and their role in facilitating and constraining the actions of actors involved in the policy process (Beland, 2007). HI defines institutions as "the formal rules, compliance procedures, and standard operating procedures that structure conflict" (Hall in Steinmo et al., 1992, p. 2). Institutions help shape policy goals as well as the operationalized objectives and policy instruments crafted to pursue these goals.

One of the fundamental purposes of $\mathrm{HI}$ is the identification and explanation of long-term policy change. Early work emphasized the role of exogenous shocks (e.g. a national crisis), which disrupted periods of policy stability and introduced new actors to political subsystems facilitating policy change (Baumgartner \& Jones, 1993; Baumgartner \& Jones, 1991). And while these 'shocks' and other exogenous factors (e.g. technology change, macroeconomic forces, power supply and demand, etc.) play a role in both defining problem sets for policymakers to address and 
identifying solutions to societal challenges, they fail to account for cases of all institutional change - particularly in cases when major external drivers of changes appear to be absent.

More recent studies highlight the role of endogenous forms of policy change (Burns, 2012; Feindt \& Flynn, 2009; Hacker et al., 2013; Howlett \& Rayner, 2013; Kay, 2007; Petek, 2018; Wellstead et al., 2016). Even during periods of apparent institutional stability, the disruption of positive feedbacks, which incentivize actors to fit into the current path and reinforce institutional political power distribution, can reshape policy path dependences. When these positive feedbacks were interrupted, new institutions can take form that helped to solidify a new path (Thelen, 1999, 2004).

However, the entrenchment of positive feedbacks often creates an environment where the removal of existing policy elements (goals, instruments, instrument settings, etc.) is difficult, if not politically impossible. Much to the frustration of new regimes, strategic and systematic policy replacement, the wholesale replacement of existing policy elements with new ones, faces resilient institutions and resistant actors that benefit from the current policy arrangement. Instead, adding new goals and policy elements to the current policy mix without removing the older ones - a process referred to as 'layering'—is more politically feasible and timely (Schickler, 2001). It is through the process of layering potentially, according to HI, that new actors, policy goals, objectives and instruments 
are added to the policy mix which result in institutional change (Van der Heijden, 2011). Table 1 provides an overview of the different components of policy mixes.

Table 1: Components of a policy mix

\begin{tabular}{|c|c|c|}
\hline & High Level Abstraction & Program Level Operationalization \\
\hline \multirow[b]{2}{*}{ Policy Aims } & Goals & Objectives \\
\hline & $\begin{array}{l}\text { What general types of ideas govern } \\
\text { policy development? (e.g. environmental } \\
\text { protection, economic development) }\end{array}$ & $\begin{array}{l}\text { What does policy formally aim to address? } \\
\text { (e.g. saving wilderness or species habitat, } \\
\text { increasing harvesting levels to create } \\
\text { processing jobs, woody biopower production) }\end{array}$ \\
\hline \multirow[b]{2}{*}{$\begin{array}{r}\text { Policy } \\
\text { Instruments }\end{array}$} & Instrument Logic & Mechanisms \\
\hline & $\begin{array}{l}\text { What general norms guide } \\
\text { implementation preferences? (e.g. } \\
\text { preferences for the use of coercive } \\
\text { instruments, or moral suasion) }\end{array}$ & $\begin{array}{l}\text { What specific types of instruments are utilized? } \\
\text { (e.g. the use of different tools such as tax } \\
\text { incentives, or public enterprises) }\end{array}$ \\
\hline
\end{tabular}

While layering gives policymakers the ability to make good on political promises, it can lead to an overarching policy mix with incompatible goals - known as "incoherence" - and policy instruments that undermine each other instead of mutually reinforcing each other-or policy "inconsistency" (Kay, 2007). The result of incompatible layers, known as "tense layering" can spark additional rounds of policy-making. The purposeful addition of new policy layers can serve as constructive policy change if it is used to enhance the consistency of the overall policy mix, otherwise known as 'patching'. The benefits of patching have been noted in previous energy-focused studies (Kern et al., 2017; Wellstead et al., 2016). Adjustment to existing policy instruments by means of changing requirements (or 
'settings') or the way the instrument is implemented ('calibration') can be used to address the adverse effects of layering.

A second form of endogenous driven policy change results from a process referred to as 'conversion'. Conversion occurs when elements of the policy mix, like policy instruments, remain intact while applying the mix to address to new goals (Howlett \& Rayner, 2013). Actors take advantage of ambiguities of definitions and rules within existing policies to pursue ends outside the bounds of the policy's original intent (Hacker et al., 2013). This can create unintended consequences dramatically different from the original policy architects' original intent. In other times, actors take an existing policy mix, or elements within it, and extend it to a new policy area. This process is referred to as policy stretching. Doing so introduces new actors, ideas and institutions into the policy mix, expanding the policy universe across new levels of government (e.g. local, state, federal, international, private/public, etc.). This can create tension, like policy incoherency, between both institutional and ideational levels as demonstrated by twentieth century British food policy (Feindt \& Flynn, 2009). Stretching can also be used by factions to build to support for a policy element. Long lasting policy instruments are often protected by powerful constituencies who firmly believe in a specific method for pursing a policy goal. By attaching additional goals to their favored instrument, these constituencies can build additional political support for the instrument, broaden its application, and even protect it from dismantling threats. 


\subsubsection{Policy Dismantling}

Policymakers and other dissatisfied stakeholders often strive to reduce the effectiveness of a policy mix's ability to achieve specific policy goals or outcomes. This process is known as "policy dismantling" and is defined by Bauer and Knill (2014) as the decrease or diminution of existing policy arrangements. Available literature on policy dismantling is limited given policy theory specialists' predominant focus on policy expansion (Jordan et al., 2013). Studies seeking to measure policy dismantling often focus on two dimensions: changes (most often decreases) in policy density and policy intensity (Bauer \& Knill, 2014). Density, as a measure of policy dismantling, refers to the quantity of general policies and policy instruments. Intensity refers to the magnitude and/or capacity of the policies to achieve policy goals. Intensity can further be delineated into substantial and formal intensity. Substantial intensity refers to the level and scope of governmental intervention; whereas formal intensity refers to factors such as administrative capacity (e.g. funding) and administrative processes that affect the policy mix's capacity to achieve its goals.

Several strategies to achieve dismantling have been identified. These strategies range from politically symbolic gestures in the form of public statements expressing a desire to reduce or remove specific polices to eliminating laws and policy instruments (Bauer \& Knill, 2014). Actions such as repealing legislation and eliminating programs are transparent forms of policy dismantling. Two less obvious forms of dismantling include arena shifting and dismantling by default. Dismantling 
through arena shifting involves shifting the decision-making process from one level of government, agency or program to another. This excludes or includes a new set of actors in the decision-making process, potentially reducing the policy mix's capacity to achieve the stated policy outcomes. Another form of dismantling can take place when relevant external socioeconomic conditions change, but policy actors purposefully freeze relevant policy instruments and their settings. An example would be automobile fuel efficiency standards set at a specified level (ex. 22 milesper-gallon) to reduce greenhouse gas emissions despite the availability of new, affordable technology to increase fuel economy standards to 30 miles-per-gallon. In this case, if the objective is to reduce greenhouse gas emissions, the policy intensity is reduced because the regulation fails to incorporate standards that can reliably and cost-effectively maximize greenhouse gas emissions reductions. This form of policy dismantling, referred to as dismantling by default, allows policymakers to reduce the policy mix's capacity to achieve policy outcomes without taking direct policy action exposing themselves to political backlash (Bauer \& Knill, 2014). 'Dismantling by default' overlaps with HI's concept of 'policy drift', which is defined as 'the failure of relevant decision-makers to update policy or institutional rules to reflect changing social circumstances in ways that are recognized by at least some political actors and consequential for the effects of those rules on society" (Hacker, 2004; Hacker et al., 2013). While in both cases (dismantling and drift) the end results are limited policy effectiveness, the difference in the two concepts rests perhaps in policymakers' intentionality. In the case of dismantling by default, policymakers intentionally hold 
the policy mix constant in order to maintain the status quo. However, it is less clear in the literature regarding drift that policymakers lack of action is a concerted effort to minimize the policy mix's effectiveness.

One of the key tenants of policy dismantling is credit taking and blame avoidance (Gravey, 2016). Actors who seek to dismantle policy mixes use strategies to minimize political costs by using low visibility approaches to avoid blame if their actions result in negative consequences (e.g. removing welfare benefits from sympathetic populations) and high visibility approaches to maximize credit for removing or weakening unpopular policies (e.g. reducing taxes) (Jordana, 2014). Energy policy dismantling takes place in a political system where the benefits of regulation (e.g. reduction in environmental contamination) are spread across society while the cost of regulation are often concentrated on a small group — often specific companies such as utilities (Jordan et al., 2013). This creates a ripe environment for dismantling since: 1) politically powerful entities such as utilities are motivated to seek changes to the policy mix; 2) the negative consequences of deregulation are spread out over a large, disperse, and comparably less politically active population (the public) generally reducing political opposition; and 3) energy regulation is often technically and legally complex, limiting policy decision to a few actors and specific policy arenas. Research indicates that actors pursuing energy policy dismantling often choose strategies that maximize blame avoidance as reduction in environmental regulations are often perceived as negatively impacting public health 
(Jordana, 2014). Table 2 provides definitions of key HI terms relevant to the remainder of this chapter.

Table 2: Historical institutionalism: Summarizing key concepts

\begin{tabular}{|l|l|l|}
\multicolumn{1}{c|}{$\begin{array}{c}\text { Historical } \\
\text { Institutional } \\
\text { Processes }\end{array}$} & \multicolumn{2}{|c|}{ Descriptions } \\
\hline Layering & $\begin{array}{l}\text { When new elements are added to an existing } \\
\text { regime without abandoning previous ones. }\end{array}$ & Schickler (2001) \\
\hline Tense Layering & $\begin{array}{l}\text { The interaction effects between two layers } \\
\text { and the consequences for the future direction } \\
\text { of a policy path. }\end{array}$ & Kay (2007) \\
\hline Stretching & $\begin{array}{l}\text { Elements of a mix are extended to cover } \\
\text { areas they were not originally intended } \\
\text { through the inclusion of new goals, actors or } \\
\text { institutions }\end{array}$ & $\begin{array}{l}\text { Feindt and } \\
\text { Flynn (2009) }\end{array}$ \\
\hline Drift & $\begin{array}{l}\text { The failure of relevant decision-makers to } \\
\text { update policy or institutional rules to reflect } \\
\text { changing social, economic or technological } \\
\text { circumstances }\end{array}$ & $\begin{array}{l}\text { Mahoney and } \\
\text { Thelen (2010) }\end{array}$ \\
\hline Tinkering & $\begin{array}{l}\text { The process of changing an instrument's } \\
\text { 'settings' (requirements) and how it is } \\
\text { 'calibrated' (implemented) }\end{array}$ & $\begin{array}{l}\text { Wellstead et al. } \\
\text { (2016) }\end{array}$ \\
\hline Dismantling & $\begin{array}{l}\text { The decrease or diminution of existing policy } \\
\text { arrangements }\end{array}$ & $\begin{array}{l}\text { Bauer and Knill } \\
\text { (2014) }\end{array}$ \\
\hline
\end{tabular}

\subsection{Policy Review}

\subsubsection{Historic Woody Biopower Output in Wisconsin}

Like national trends, the use of woody biomass as a feedstock for power generation in Wisconsin has been driven by the industrial forest products sector, such as paper and wood products manufacturers using wood waste byproducts to provide heat and power for their facilities. This accounted for $68 \%$ of woody biomass energy generated energy in the U.S. 2007 (Aguilar et al., 2011). The Wisconsin industrial 
sector's share of woody biopower has remained remarkably consistent since 1990 (see Figure 1), around an annual rate of 600,000 megawatt hours (MWh) (Energy Information Administration, 2017) or the equivalent of powering approximately 56,000 Wisconsin homes for one year (U.S. Energy Information Administration, 2017). It is important to note however, that this figure includes both power and heat produced from woody biomaterials, so this figure over represents the actual amount of electricity produced. In 2016, approximately 880,000 megawatt hours of energy in the state of Wisconsin, and approximately $64.7 \%$ of that energy $(569,569 \mathrm{MWh})$ was produced in the form of heat and electricity by the industrial sector. Electric utility use of woody biomass has been more volatile. Despite annually averaging 185,000 MWh since 1990, the sector experienced a major drop off in woody biopower generation in 2001, declining from the previous year's level of 163,000 MWh to only 23,000 MWh. Since that time, the industry has steadily increased electricity production from woody biomass reaching a peak of 310,080 MWh in 2016.

Independent power producers (IPPs), which are non-utility power generators, also experience volatile woody biomass power production. IPPs have played an important role in power production from woody biomaterials beginning in 2010 and accounted for more than 300,000 MWh in 2013. However, their production quickly declined and fell by nearly half by 2015. Prior to 2010, IPPs generated no electricity from woody biomass in Wisconsin. 


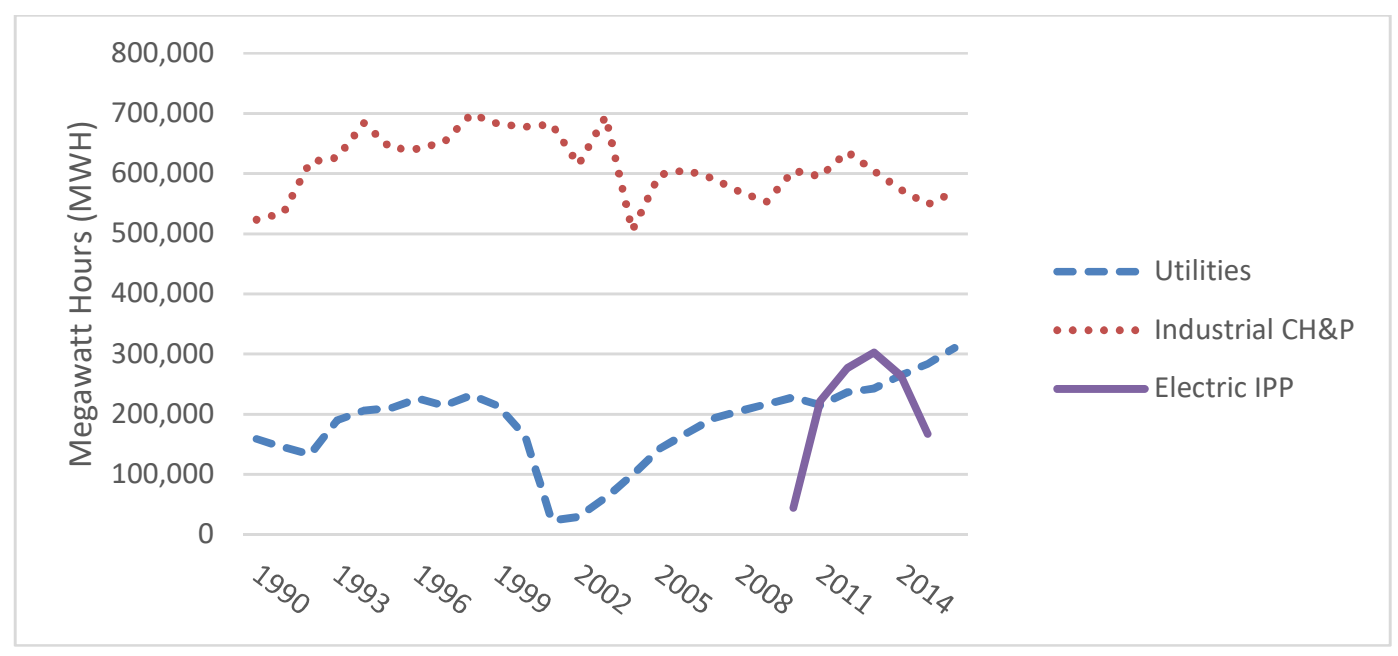

Figure 1: Wisconsin woody biomass power generation by producer type (1990-2016) Source: U.S. Energy Information Administration (2017).

\subsubsection{Policy Overview 1993-2015}

In order to evaluate the influences of layering on the Wisconsin woody biopower policy mix, I inventoried more than two decades of relevant state policies. Table 3 highlights relevant state policies influencing Wisconsin's RPS and subsequent woody biopower development and indicates the type of instrument(s) and settings selected in addition to the affect (decrease or increase) on the policy mix's policy density or intensity. Table 4 reflects the stated operationalized objectives and inferred abstract policy goals of the relevant state policies during this period.

To incorporate the influence of actors, who can help introduce or prevent new ideas from entering into the policy mix, into analysis, I used the Wisconsin Ethics Commission's database of registered lobbying efforts on state legislative bills. The database, which only goes back to the 2003-2004 legislative period, provides a list or 
registered lobbying organizations by proposed bill, the organization's stated position on the bill (support, oppose, undisclosed/other), and the reported number of hours each organization spent lobbying on the bill. These data can provide a means to understand which actors were involved in the legislative process and a general idea of who supported or opposed a proposed bill. The reported lobbying hours can also provide some idea of the intensity and resources that organizations dedicated to their position and help explain causes of institutional change through layering, conversion, and drift (Rocco \& Thurston, 2014). Many policies can be packaged into any given bill, particularly in large biennial budget bills. Therefore, specific lobbying goals can be difficult to ascertain as detailed explanation for support or opposition of the bill is often not provided. In these cases, I did not attempt to quantify stakeholder support or opposition. Despite these limitations, this process can show how the involvement of actors changed over the period of analysis and potentially explain how this influenced the overall course of policy support for woody biopower production. 
Table 3: Wisconsin legislation and policies impacting the RPS \& woody biopower (19932015)

\begin{tabular}{|c|c|c|c|}
\hline $\begin{array}{l}\text { Legislative } \\
\text { Session Year }\end{array}$ & Legislation/Policy & Instruments \& Settings & $\begin{array}{c}\text { Policy } \\
\text { Change }\end{array}$ \\
\hline 1993 & $\begin{array}{l}\text { Wisconsin Act } 414 \text { Energy } \\
\text { Priority Act }\end{array}$ & $\begin{array}{l}\text { Established Priorities List for DOA } \\
\text { and Public Service Commission } \\
\text { (PSC) in designing and implementing } \\
\text { energy programs and making energy } \\
\text { - } \quad \text { Prioritized renewable energy over } \\
\text { fossil fuel combustion options }\end{array}$ & - $\quad+\mathrm{R}$ \\
\hline 1997 & $\begin{array}{l}\text { Wisconsin Act } 204 \text { Electric } \\
\text { Reliability Act }\end{array}$ & $\begin{array}{l}\text { Required eastern Wisconsin utilities } \\
\text { to construct or procure a total of } 50 \\
\text { MW of new electric capacity } \\
\text { generated from renewable energy } \\
\text { sources. } \\
\text { Required study of regional } \\
\text { transmission capacity }\end{array}$ & $\begin{array}{ll}\cdot & +\mathrm{R} \\
\bullet & +\mathrm{I}\end{array}$ \\
\hline 1999 & $\begin{array}{c}\text { Wisconsin Act } 9 \text { 1999-2001 } \\
\text { Biennial Budget }\end{array}$ & $\begin{array}{l}\text { - } \quad \text { Established state RPS with a goal of } \\
2.2 \% \text { by } 2011\end{array}$ & - $\quad+\mathrm{R}$ \\
\hline 2005 & Wisconsin Act 141 & $\begin{array}{ll}\text { - } & \text { Increased statewide RPS to } 10 \% \text { by } \\
2015 \\
\text { - }\end{array}$ & $\begin{array}{ll}- & +\mathrm{R} \\
\bullet & +\mathrm{I} \\
\bullet & +\mathrm{F} \\
- & -\mathrm{R}\end{array}$ \\
\hline 2005 & $\begin{array}{c}\text { Wisconsin Act } 25 \\
\text { 2005-2007 Biennial Budget }\end{array}$ & $\begin{array}{l}\text { Authorized grants for research and } \\
\text { development to facilitate the } \\
\text { commercialization forest biomass to } \\
\text { energy }\end{array}$ & - $\quad+\mathrm{F}$ \\
\hline 2007 & Wisconsin Act 20 & $\begin{array}{ll}- & \text { Established Wisconsin Office of } \\
\text { Energy Independence }\end{array}$ & - $\quad+\mathrm{O}$ \\
\hline 2008 & $\begin{array}{c}\text { Wisconsin Strategy for } \\
\text { Reducing Global Warming }\end{array}$ & $\begin{array}{l}\text { - Provided policy recommendations to } \\
\text { mitigate climate change }\end{array}$ & - $\quad+$ I \\
\hline 2009 & Wisconsin Act 269 & $\begin{array}{l}\text { - Created } 10 \% \text { tax credit for biomass } \\
\text { equipment } \\
\text { Authorizes up to } \$ 900,000 \text { in total } \\
\text { harvesting and process equipment } \\
\text { credits per year }\end{array}$ & - $\quad+\mathrm{F}$ \\
\hline 2009 & Wisconsin Act 401 & $\begin{array}{ll}\text { - } & \text { Expanded financial assistance for } \\
\text { bioenergy conversion facilities, other } \\
\text { supply chain elements and R\&D } \\
\text { - } \quad \text { Required biennial strategic bioenergy } \\
\text { feedstock assessment } \\
\text { - } \quad \text { Established Bioenergy Council } \\
\end{array}$ & $\begin{array}{ll}- & +\mathrm{F} \\
\bullet & +\mathrm{I} \\
\bullet & +\mathrm{O}\end{array}$ \\
\hline 2009 & $\begin{array}{l}\text { Woody Biomass Harvesting } \\
\text { Guidelines }\end{array}$ & $\begin{array}{l}\text { Voluntary guidelines for woody } \\
\text { biomass removal, stand and site-level } \\
\text { management in response to forest- } \\
\text { based ecosystem service effects of } \\
\text { biomass harvesting }\end{array}$ & - $\quad+$ I \\
\hline
\end{tabular}




\begin{tabular}{|c|c|c|c|}
\hline 2009 & Wisconsin Act 406 & $\begin{array}{l}\text { Expanded qualified RPS energy } \\
\text { sources to include synthetic gas and } \\
\text { fuel pellets from waste materials (but } \\
\text { not garbage) } \\
\text { - } \begin{array}{l}\text { Established a new credit based on } \\
\text { certain new non-electric forms of } \\
\text { energy }\end{array} \\
\end{array}$ & - $\quad-\mathrm{R}$ \\
\hline 2011 & $\begin{array}{c}\text { Wisconsin Act } 32 \text { 2011-2013 } \\
\text { Biennial Budget }\end{array}$ & $\begin{array}{l}\text { Eliminated the Office of Energy } \\
\text { Independence by absorbing its duties } \\
\text { into DOA as part of the State Energy } \\
\text { Office }\end{array}$ & - $-\mathrm{O}$ \\
\hline 2011 & Wisconsin Act 34 & $\begin{array}{ll}\text { Expanded qualified RPS energy } \\
\text { sources to include new hydroelectric } \\
\text { generating facilities larger than } 60 \\
\text { MW }\end{array}$ & - $\quad-\mathrm{R}$ \\
\hline 2013 & Wisconsin Act 290 & $\begin{array}{l}\text { - } \\
\text { bllowed electric providers whose } \\
\text { baseline renewable percentage (BRP) } \\
\text { exceeds } 12 \% \text { and whose renewable } \\
\text { energy percentage (REP) exceeds } \\
14 \% \text { to reduce its } 2015 \text { (and future) } \\
\text { must maintain its REP at least } 2 \% \\
\text { points above its BRP (originally } \\
\text { required to be } 6 \% \text { ) }\end{array}$ & - $\quad-\mathrm{R}$ \\
\hline 2013 & Wisconsin Act 300 & $\begin{array}{l}\text { Allowed electric providers to create } \\
\text { credits on non-electric forms of } \\
\text { renewable energy regardless of the } \\
\text { date when source was put in place }\end{array}$ & - $\quad-\mathrm{R}$ \\
\hline
\end{tabular}


Table 4: Goals and objectives of Wisconsin policies impacting the RPS and woody biopower (1993-2015)

\begin{tabular}{|c|c|c|c|}
\hline $\begin{array}{c}\text { Legislative Session } \\
\text { Year }\end{array}$ & Legislation/Policy & $\begin{array}{c}\text { High Level } \\
\text { Abstraction Goals }\end{array}$ & $\begin{array}{c}\text { Program Level } \\
\text { Operationalization } \\
\text { Objectives }\end{array}$ \\
\hline 1993 & $\begin{array}{l}\text { Wisconsin Act } 414 \\
\text { Energy Priority Act }\end{array}$ & 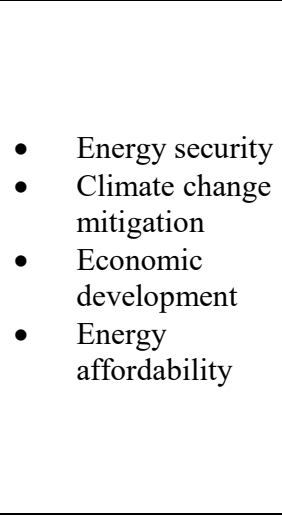 & $\begin{array}{l}\text { Promotes indigenous, } \\
\text { sustainable energy resources } \\
\text { to minimize the amount of } \\
\text { non-sustainable energy } \\
\text { purchased from out-side of } \\
\text { state } \\
\text { Cost-effective and } \\
\text { technically feasible } \\
\text { renewable energy } \\
\text { - } \quad \text { Enhances job creation } \\
\text { Reduces atmospheric carbon } \\
\text { dioxide and ensure future } \\
\text { supply of wood through } \\
\text { afforestation }\end{array}$ \\
\hline 1997 & $\begin{array}{l}\text { Wisconsin Act } 204 \\
\text { Electric Reliability } \\
\text { Act }\end{array}$ & - $\quad$ Energy security & $\begin{array}{l}\text { Increases the reliability of } \\
\text { state's electric supply } \\
\text { Provides in-state retail price } \\
\text { competition }\end{array}$ \\
\hline 1999 & $\begin{array}{l}\text { Wisconsin Act } 9 \\
\text { 1999-2001 Biennial } \\
\text { Budget }\end{array}$ & $\begin{array}{ll}\text { - } & \begin{array}{l}\text { Economic } \\
\text { development }\end{array} \\
\text { - } & \text { Climate change } \\
& \text { mitigation } \\
\text { - } & \text { Energy security } \\
\end{array}$ & $\begin{array}{l}\text { - } \quad \text { RPS: Increase in-state sales } \\
\text { of renewable electricity }\end{array}$ \\
\hline 2005 & Wisconsin Act 141 & $\begin{array}{ll}\text { - } & \text { Economic } \\
& \text { development } \\
\text { - } & \text { Energy security } \\
\text { - } & \text { Climate change } \\
& \text { mitigation }\end{array}$ & $\begin{array}{ll}- & \text { Facilitates economic growth } \\
\text { - } & \text { Reduces dependence on out- } \\
\text { of-state energy sources } \\
\text { - } & \begin{array}{l}\text { Protects state's natural } \\
\text { resources }\end{array} \\
\text { - } & \begin{array}{l}\text { Reduces the need for } \\
\text { traditional fossil-fuel plants }\end{array} \\
\text { - } & \begin{array}{l}\text { Increase energy conservation } \\
\text { and use of renewable energy }\end{array} \\
\end{array}$ \\
\hline 2005 & $\begin{array}{l}\text { Wisconsin Act } 25 \\
\text { 2005-2007 Biennial } \\
\text { Budget }\end{array}$ & $\begin{array}{ll}\text { - } & \begin{array}{l}\text { Economic } \\
\text { development }\end{array} \\
\text { - } & \text { Climate change } \\
\text { mitigation }\end{array}$ & $\begin{array}{ll}\text { - } & \text { Facilitates forestry biomass } \\
\text { energy production } \\
\text { - } & \text { Supports forestry products } \\
\text { industry }\end{array}$ \\
\hline 2007 & Wisconsin Act 20 & $\begin{array}{ll}\text { - } & \begin{array}{l}\text { Economic } \\
\text { development }\end{array} \\
\text { - } & \text { Energy security } \\
\text { - } & \text { Climate change } \\
& \text { mitigation }\end{array}$ & $\begin{array}{l}\text { Generates at least } 25 \% \\
\text { percent of power used in the } \\
\text { state from renewable } \\
\text { resources by } 2025 \\
\text { - } \quad \text { Captures in-state at least } \\
10 \% \text { of the national } \\
\text { bioindustry and renewable } \\
\text { energy markets by } 2030 \\
\text { Ensures that Wisconsin is a } \\
\text { national leader alternative } \\
\text { energy research } \\
\text { Creates well-paying jobs in } \\
\text { the state }\end{array}$ \\
\hline
\end{tabular}




\begin{tabular}{|c|c|c|c|}
\hline 2008 & $\begin{array}{l}\text { Wisconsin Strategy } \\
\text { for Reducing Global } \\
\text { Warming }\end{array}$ & $\begin{array}{l}\text { - Climate change } \\
\text { mitigation }\end{array}$ & $\begin{array}{ll}\text { - } & \text { Reduces greenhouse gas } \\
\text { emissions } \\
\text { - } & \text { Enhances research \& } \\
\text { development funding } \\
\text { - } & \text { Conserves energy } \\
\text { - } & \text { Enhances RPS } \\
\end{array}$ \\
\hline 2009 & $\begin{array}{l}\text { Woody Biomass } \\
\text { Harvesting } \\
\text { Guidelines }\end{array}$ & $\begin{array}{l}\text { Environmental } \\
\text { protection }\end{array}$ & $\begin{array}{l}\text { Reduces negative impact of } \\
\text { woody biomass removal on } \\
\text { forest ecosystems }\end{array}$ \\
\hline 2009 & Wisconsin Act 269 & $\begin{array}{ll}\text { - } & \begin{array}{l}\text { Economic } \\
\text { development }\end{array} \\
\text { - } & \text { Bioenergy } \\
\text { production }\end{array}$ & $\begin{array}{l}\text { Enhances cost effectiveness } \\
\text { of biomass production }\end{array}$ \\
\hline 2009 & Wisconsin Act 401 & $\begin{array}{ll}- & \text { Energy security } \\
\text { - } & \text { Economic } \\
\text { development } \\
\text { - } \\
\text { Climate change } \\
\text { mitigation } \\
\end{array}$ & $\begin{array}{ll}- & \text { Boosts renewable energy } \\
\text { research } \\
\text { - } & \text { Job creation } \\
\text { - } & \text { Energy independence } \\
\text { - } & \text { Forestry diversification } \\
\end{array}$ \\
\hline 2009 & Wisconsin Act 406 & $\begin{array}{l}\text { - Climate change } \\
\text { mitigation } \\
\text { Energy } \\
\text { affordability }\end{array}$ & $\begin{array}{l}\text { Enhances use of renewable } \\
\text { sources such as solar, } \\
\text { geothermal, and biomass } \\
\text { Decreases the cost of } \\
\text { compliance with RPS and } \\
\text { reduced electricity rates }\end{array}$ \\
\hline 2009 & $\begin{array}{l}\text { Woody Biomass } \\
\text { Harvesting } \\
\text { Guidelines }\end{array}$ & $\begin{array}{l}\text { - Environmental } \\
\text { protection }\end{array}$ & $\begin{array}{l}\text { - Limits the impacts of } \\
\text { harvesting of woody biomass } \\
\text { on: a) biodiversity } \\
\text { conservation, b) soil nutrient } \\
\text { depletion, c) physical } \\
\text { properties of soil, and d) } \\
\text { water quality }\end{array}$ \\
\hline 2011 & $\begin{array}{l}\text { Wisconsin Act } 32 \\
\text { 2011-2013 Biennial } \\
\text { Budget }\end{array}$ & $\begin{array}{ll}\text { - } & \text { Government } \\
\text { efficiency } \\
\text { - } & \text { Energy } \\
\text { affordability } \\
\text { - } & \begin{array}{l}\text { Economic } \\
\text { development }\end{array} \\
\end{array}$ & $\begin{array}{ll}\text { - } & \text { Stream-lines government } \\
\text { efficiency } \\
\text { Cost-effective, balanced, } \\
\text { reliable, and environmentally } \\
\text { responsible energy } \\
\text { promoting economic growth }\end{array}$ \\
\hline 2011 & Wisconsin Act 34 & $\begin{array}{l}\text { - } \quad \text { Energy } \\
\text { affordability }\end{array}$ & $\begin{array}{l}\text { Keeps electric bills from } \\
\text { increasing, make green } \\
\text { energy mandates more } \\
\text { affordable }\end{array}$ \\
\hline 2013 & Wisconsin Act 290 & $\begin{array}{l}\text { - } \quad \text { Energy } \\
\text { affordability }\end{array}$ & $\begin{array}{l}\text { Relieves ratepayers of extra } \\
\text { costs associated with four } \\
\text { utilities' disproportionate } \\
\text { 2015 RPS requirements }\end{array}$ \\
\hline 2013 & Wisconsin Act 300 & $\begin{array}{ll}- & \text { Energy } \\
& \text { affordability }\end{array}$ & $\begin{array}{l}\text { - } \quad \text { Not stated; pertaining to } \\
\text { Renewable Resource Credit }\end{array}$ \\
\hline
\end{tabular}




\subsubsection{3 - 1998: Enhancing Energy Independence and Electric Reliability through Renewable Electric Generation}

Between 1993 and 1998, Wisconsin policymakers enacted policies with the goal of using renewable power generation to reduce the state's reliance on imported fossil fuels and enhance the overall reliability of the state's electric grid. Although Wisconsin's RPS was created in 1999, its origin can be traced back six years earlier to the passage of the 1993 Energy Priority Law (Act 414), which established a goal of "all new installed capacity for electric generation in the state be based on renewable energy resources...”. Prompted by the state's lack of fossil fuel resources, the price volatility of natural gas and concerns of environmental impacts, the Act effectively established energy efficiency and renewable sources as the primary goals of the state's energy policy (La Follette, 2004) as a way to reduce the state's dependence on imported energy sources (and subsequent price increases). Under then Governor Tommy Thompson (R), the Act required the Wisconsin Department of Administration (DOA) and Public Service Commission of Wisconsin (WPSC) (as well as other state agencies) to prioritize 1) energy conservation and efficiency, 2) noncombustible renewable energy sources, and 3) combustible renewable energy sources above the use of nonrenewable energy sources such as natural gas and coal when regulating the state's electric and gas utilities. While the Act fell short of guaranteeing renewable power generation from regulated utilities, it did require that renewables be considered when requesting permission from the WPSC for new generation development (1993 Wisconsin Act 414, 1994). 
Despite the state's desire for renewable generation, the Act stipulated that prioritization had to keep cost effectiveness and technical feasibility in mind, and specifically stated that the legislature wished to avoid "inflexible mandates or deprive decision makers of the discretion needed to respond appropriately to circumstances surrounding energy-related decisions" (1993 Wisconsin Act 414, 1994). This afforded utilities and state agencies discretion regarding new generation decisions and placed economic and technical considerations at equal levels with the objective of renewable power generation.

Importantly for the woody biopower industry, Act 414 introduced several policy instruments and settings that helped support the use of wood for power production. First, a critical instrument setting under the Energy Priority Law was the inclusion of wood as an eligible source of renewable energy. This meant, all other factors being equal, that a woody biopower facility was preferred by the WPSC over fossil fuel generation projects. Second, the law created a series of financial instruments to reduce the cost of renewable energy projects and technologies. Third, section 15 of the Act required the Wisconsin Department of Agriculture, Trade and Consumer Protection (WDATCP) to prepare a report regarding the capacity of forestlands to provide biomass for utility and commercial power generation and home heating systems. The legislature required WDATCP to produce the report every two years, signaling the state's interest in woody biopower as a potential energy source. 
The 1997 Electric Reliability Act (Wisconsin Act 204 Act) represented a change in the state's instrument logic by increasing its use of mandates for renewable generation. A series of power plant maintenance shutdowns in the summer of 1997 stimulated concerns that the state's power system was susceptible to blackouts. The shutdowns nearly overloaded power transfer into the state and brought to light the fact that much of the system's transmission capacity transporting cheap power from western states and Canadian provinces was operating near full capacity. These circumstances led to the passage of the 1997 Wisconsin Act 204 which mandated utilities in eastern Wisconsin construct 50 megawatts of new capacity using renewable energy sources such as biomass in addition to transmission upgrades and capacity studies (Ritsche, 1998). The Act established that renewable generation was a component of energy reliability and moved away from stipulations requiring that cost effectiveness be a primary factor when considering renewable generation. In addition, the Act signaled that the state was willing to use top-down mandates as a policy instrument to advance renewable generation in contrast to Act 414, which called for flexibility and discretion for WPSC decisions related to power generation sources. Importantly, the language for Act 414's energy priorities list remained intact creating an example of "tense layering" given the priority list's emphasis on economic and technical considerations when considering renewable power development.

Act 204 also paved the way for independent power producers in Wisconsin to support the reliability of Wisconsin's electric grid but added a new policy layer 
creating tension between meeting reliability and affordability goals. Prior to the Act, power plants could only be constructed in Wisconsin if the utility could prove that the plant was necessary to meet project energy demand. While this helped to minimize over construction of power plants (keeping rates lower), it made utilities vulnerable to rapid and unanticipated demand increases (e.g. economic shifts or unusually hot summers). Act 204 allowed for non-utility private sector entities to construct power plants without proof of necessity and required utilities to enter into long-term purchase agreements with these producers, which helped bolster the amount of generation capacity in the state (Flaherty, 2012). These independent power producers accounted for a large portion of woody biopower production between 2010 and 2015 (see Figure 1) and would be responsible for generating a significant portion of the state's legislatively-required renewable power during the next decade.

\subsubsection{9 - 2004: Renewable Portfolio Standard \& Climate Change}

Wisconsin's drive for renewable energy generation culminated in the passage of the 1999 budget bill (Wisconsin Act 9), which established the first state RPS absent state electric retail competition. The creation of the RPS, which introduced a credit trading program to shape regulated utilities power sources, superimposed a new layer over the existing policy framework creating tension between the mix's elements, particularly the Energy Priority Law. 
At the time, states across the country were embroiled in electric market deregulation, and Wisconsin's RPS was a small component of the state's larger strategy of enhanced wholesale market competition. Championed by a coalition of environmentalists, utilities and industry stakeholders as part of a larger push for electric regulatory reforms, RPS advocates promoted the policy instrument as a means to provide economic development, environmental and electric reliability benefits (Center for Resource Solutions, 2000). Embedded in the 743-page annual budget bill, the state passed a modest goal that required $2.2 \%$ all electricity retail sales come from renewable sources by 2011. Importantly, the legislation created statute 196.378, which officially defined "renewable resources", which included biomass but excluded electricity generated from hydroelectricity systems greater than $60 \mathrm{MW}$. It also included wood as an eligible source of biomass and outlined the use of co-firing biomass with fossil fuels as a means to achieve the RPS mandate. In addition, the legislation outlined a credit generation and trading scheme for utilities to meet RPS requirements and created the penalties if they did not achieve the standards (1999 Wisconsin Act 9, 1999). Ultimately, this component of Act 9 signified the state's increased willingness to use mandates and market-based mechanisms as policy instruments to advance goals tied to renewable energy. However, Wisconsin's RPS focused on sales of renewable electricity, not necessarily renewable generation. In other words, this policy allowed utilities to purchase renewable generation from other sources, often from out-of-state, which was a 
departure from previous policies that specifically required or steward in-state generation from renewable sources.

\subsubsection{5 - 2010: Policy Layering, Tinkering and Woody Biopower}

Legislation passed between 2005 and 2010 can best be described as a period of smart policy design. During this period policymakers introduced several policy layers and tinkering efforts to support the development of renewable power and bolster the woody biopower industry while eliminating tension between previous policy layers by eliminating the energy priorities list. As will be discussed below, policymakers moved to expand the RPS while introducing new institutions and financial tools to support renewable energy research and development.

Act 141 bolstered the state's demand for renewable electricity and the market for woody biopower by increasing the state's RPS requirements and requiring state agencies to procure renewable sources of energy. The passage of Act 141 was

justified to facilitate economic growth; further reduce dependence on out-of-state energy sources; protect state's natural resources by way of reducing greenhouse gas emissions; and reduce the need for traditional fossil-fuel power plants. The original requirement that established 2.2\% in Act 9 (1999) was increased to $10 \%$ of retail sales by utilities from renewable energy sources by 2015. This represents a form of policy 'tinkering' as it adjusted the RPS instruments setting in favor of more renewable energy. Second, and consistent with the objective to grow the market for renewable power, Act 141 added a new policy layer by requiring many state 
agencies like the DOA, Departments of Corrections, Health and Family Services, Public Instruction, Veterans Affairs, and the UW System Board of Regents to purchase at least $20 \%$ of their total annual electricity from renewable sources by the close of 2011. Third, it clarified the renewable resource credit trading program established in Act 9 in 1999 to improve market conditions for renewable power development.

These actions helped to enhance the demand for renewable electricity sales; however, the Act also limited the application of the WPSC's energy priorities list created in Act 414 that sought to enhance renewable generation within the state. Conceivably, a utility could meet its mandated renewable energy sales obligation of the new RPS settings, yet under the prior energy priorities list, still be required to prioritize renewable energy projects if new generation was needed. While the two policies certainly steered in the same direction (displacing fossil fuels with renewable energy, addressing climate change, promoting in-state power production, etc.), legislators considered the priority list requirements satisfied if utilities achieved the new RPS requirements indicating a tension between the two policies. However, Act 141 removed the WPSC's ability to impose additional renewable resource requirements on investor-owned utilities and wholesale electricity suppliers above the RPS requirements (2005 Wisconsin Act 141, 2006). Consequently, new proposed generation projects reviewed by WPSC could not prioritize renewable power sources like woody biomass if the utility's RPS requirements were met. By 
removing the capacity of the WPSC to implement the energy priorities list, the state lost a major mechanism for increasing in-state renewable generation.

The expansion of the RPS was facilitated through broad support across a myriad of interest groups. Table 5 displays an overview of support and opposition by different interest groups for the legislation based on reported lobbying efforts to the Wisconsin Ethics Commission $(2006)^{2}$. As shown below, the legislation experienced a coalition of support, led by utility lobbying groups such as Alliant Energy Corporation, Wisconsin Energy Corporation, and Northern State Power. The legislation was also supported by labor unions, renewable energy, consumer protection, environmental, and dairy lobbyist groups. The only lobby group on record opposing the bill was the John Muir Chapter of the Sierra Club, which believed that the legislation fell short of achieving more aggressive sustainability goals, suggesting that the instrument could experience elements of drift given the declining costs and increasing efficiencies of renewable energy technologies (Mahoney \& Thelen, 2010). Records show more than 3,200 hours dedicated to lobbying efforts related to Act 141 . Nearly a quarter of those lobbying hours (776 hours) were generated by Alliant Energy Corporation followed by Energy Efficiency \& Renewables Group (EERG), an organization dedicated to enhancing investment in energy efficiency and renewable energy in Wisconsin, with nearly 500 lobbying hours. Wisconsin Energy Corporation (321 hours), Wisconsin Public Interest

\footnotetext{
${ }^{2}$ Records from the Wisconsin Ethics Commission online database begin during the 2003-2004 Wisconsin legislative session.
} 
Research Group (258 hours), and Northern States Power (154 hours) rounded out the top five lobbying groups, which represented more than $60 \%$ of lobbying hours attributed to Act 141 .

Table 5: Lobbying support for 2005 Wisconsin Act 141

\begin{tabular}{|l|c|c|c|c|}
\hline \multicolumn{1}{|c|}{ Interest Group } & Support & Oppose & Undisclosed/Other & Total \\
\hline Utility & 8 & 0 & 4 & 12 \\
\hline Labor Union & 4 & 0 & 2 & 6 \\
\hline Renewable Energy & 3 & 0 & 0 & 3 \\
\hline Consumer Protection & 2 & 0 & 0 & 2 \\
\hline Environmental & 1 & 1 & 1 & 3 \\
\hline Energy Efficiency & 0 & 0 & 1 & 1 \\
\hline Forest Products & 0 & 0 & 1 & 1 \\
\hline Health & 0 & 0 & 1 & 17 \\
\hline Other & 6 & 0 & 11 & 46 \\
\hline Total & 24 & 1 & 21 & \\
\hline Source: Wisconsin Ethics Commission (2006)
\end{tabular}

In 2007, the state created the Wisconsin Office of Energy Independence (WOEI) as part of the executive annual budget (2007 Wisconsin Act 20). The objectives for WOEI were quite ambitious: 1) advance the state's pursuit of energy independence by generating $25 \%$ of Wisconsin's power and $25 \%$ Wisconsin's transportation fuels from renewable sources by $2025 ; 2$ ) capture in-state at least $10 \%$ of the national emerging bio-industry and renewable energy markets by 2030; and 3) ensure that Wisconsin is a national leader in groundbreaking research that will make alternative energies more affordable and create well-paying jobs in the state (2007 Wisconsin Act 20, 2007). The office's primary responsibilities included 1) facilitating the implementation of the goals stated above; and 2) serving as the point 
of contact for all aspects of bio-based research and development for energy production. This policy instrument clearly focused on enhancing in-state renewable electricity generation and encapsulated the administration's desire to take advantage of its abundant biomass resources and represented the first major use of a policy organization instrument with the potential of leveraging woody biopower development.

In 2008, then Governor Jim Doyle received the final report stemming from Executive Order 191 to develop Wisconsin’s Strategy for Reducing Global Warming. The report included an inventory of the state's greenhouse gas sources and offered numerous policy recommendations to reduce greenhouse gas emissions, most notably to increase the state's RPS to $25 \%$ by 2025 . The recommendation supported the Sierra Club's position that the RPS' settings increase was too low, providing evidence of potential drift. Other recommendations included increased uptake of energy efficiency technologies and practices, enhanced investment in research and development, and growth of tax incentives for renewable energy. The strategy document specifically recommended increasing the use of biomass for energy production, including electricity, and requested incentives for landowners to grow energy crops and investments in energy harvesting equipment and transportation equipment (Nelson \& Thilly, 2008).

While much of this period focused broadly on renewable energy markets, the state added several policy instruments to support woody biopower production. In 2005, the state's biennial budget bill passed established a grant specifically to assist 
the commercialization of technology to enhance energy generation from forest biomaterials (2005 Wisconsin Act 25, 2005). The bill provided grants for up to $\$ 300,000$ to non-profit organizations to conduct research and development projects focusing on using byproducts and waste generated from forestry operations to produce energy. In 2010, the state passed Act 269 creating tax credits (10\% of qualifying expenses up to $\$ 900,000$ per fiscal year) to subsidize the cost of woody biomass harvesting and processing equipment in which the biomass was used as fuel or a component of fuel (2009 Wisconsin Act 269, 2010). Additional financial assistance and organizational policy instruments were created to aid the woody biopower industry through the 2009 Wisconsin Act 401, which focused on providing support for the state's bioeconomy and included both biopower and biofuels (fuels derived from biomass sources). Act 401 did the following: 1) established grants and subsidized loans to construct biomass conversion facilities; 2) required WOEI to prepare a biennial strategic bioenergy feedstock assessment to help evaluate biomass resources for energy production; 3) made available funding for research and development of forest products for fuels, heat, or electricity; 4) designated timber and wood products as agricultural commodities allowing the Department of Agriculture, Trade, and Consumer Protection (DATCP) to promote their use; and 5) created a bioenergy advisory council under DATCP to identify best management practices for sustainable biomass and biofuels production (2009 Wisconsin Act 401, 2010). The cumulative effect of these policy instruments was intended to stimulate increased generation of energy, including electricity from biomass sources and in 
many cases were meant to make power production from woody biomass more competitive with other sources of energy.

Unlike the RPS expansion, the creation of supporting layers for the woody biopower industry included just a handful of actors. Tables $6 \& 7$ provide an overview of reported interest groups involved in lobbying for Acts 269 and 401, respectively (Wisconsin Ethics Commission, 2010a, 2010c). Regarding Act 269, two major forest products organizations, Plum Creek Timber Company and Timber Producers Association of Michigan \& Wisconsin, along with Wisconsin Energy Corporation, a major Wisconsin utility, supported the legislation. Act 401, with its emphasis on biofuel production, built a coalition of environmental, health, biofuel and agriculture production advocacy groups to pass legislation that created policy instruments supportive of woody biopower production (Wisconsin Ethics Commission, 2010c). Primary opposition efforts were led by the automobile transportation industry and the Wisconsin Manufacturers \& Commerce lobbying group (classified as economic development) as shown in Table 7.

Table 6: Lobbying support for 2009 Wisconsin Act 269

\begin{tabular}{|l|r|r|r|r|}
\hline \multicolumn{1}{|c}{ Interest groups } & Support & \multicolumn{1}{c|}{ Oppose } & \multicolumn{1}{c|}{ Undisclosed/Other } & Total \\
\hline Forest Products & 2 & 0 & 0 & 2 \\
\hline Utility & 1 & 0 & 1 & 2 \\
\hline Economic Development & 0 & 0 & 1 & 1 \\
\hline Total & 3 & 0 & 2 & 5 \\
\hline Source: Wisconsin Ethics Commission (2010a) \\
\hline
\end{tabular}


Table 7: Lobbying support for 2009 Wisconsin Act 401

\begin{tabular}{|l|c|c|c|c|}
\hline \multicolumn{1}{|c}{ Stakeholder } & Support & Oppose & \multicolumn{1}{c|}{ Undisclosed } & Total \\
\hline Environmental & 3 & 0 & 0 & 3 \\
\hline Health & 1 & 0 & 0 & 1 \\
\hline Biofuels & 1 & 0 & 0 & 1 \\
\hline Agriculture & 1 & 0 & 1 & 2 \\
\hline Forest Products & 0 & 0 & 1 & 1 \\
\hline Utility & 0 & 0 & 1 & 1 \\
\hline Petroleum & 0 & 0 & 6 & 6 \\
\hline Economic Development & 0 & 1 & 1 & 2 \\
\hline Transportation & 0 & 4 & 1 & 5 \\
\hline Total & 6 & 5 & 11 & 22 \\
\hline Source: Wisconsin Ethics Commission (2010c) & \\
\hline
\end{tabular}

Despite amending statue 196.378 to include new fuel sources that potentially incorporated woody biomass (synthetic gas created by gasification of waste materials, densified fuel pellets or fuel produced by pyrolysis of organic or waste material) the passage of the 2009 Wisconsin Act 406 (enacted in 2010) also served as the beginning of a period of "dilution" of the state's RPS whereby successive layers of policies were added to reduce the policy mix's capacity to effectively achieve its goal of instate renewable power generation. In addition to including new qualified renewable energy sources, the Act created a new type of credit eligible for helping utilities meet RPS standards. Under the Act 406, credits could be generated by displacing non-electric sources of energy (e.g. heat) with renewable sources by an electric provider or its customer or members if that energy would have been generated from conventional fossil fuel sources. Renewable sources included solar thermal applications, geothermal, biomass and biogas application, etc. (2009 
Wisconsin Act 406, 2010). Effectively, this allowed utility providers to achieve RPS mandates by counting its customers' use of renewable sources for activities like heat production. Doing so lowers the utilities' need to produce or procure renewable electricity required by the RPS (Wisconsin Public Service 2012b). Upon implementing the policy, the WPSC promulgated a rule only allowing non-electric credits to be generated from sources put into place after the enactment of Act 406 .

The passage of Act 406 was widely supported by a coalition of utility, labor union, and energy efficiency groups. But unlike the passage of the RPS expansion (Act 141), economic development organizations like chambers of commerce, industrial energy groups, and business councils also committed lobbying efforts to support the new form of renewable energy credit (Table 8). Greenwood Fuels, a producer of fuel pellets from paper and plastics and a potential beneficiary of the new RPS credit, also supported the bill. In stark contrast to Act 141, environmental groups collectively opposed Act 406. Five environmental groups reported lobbying efforts related to Act 406, and four opposed the bill with one not declaring a position. The Sierra Club and Wisconsin Environment, Inc. both opposed the bill because they viewed it as weakening the RPS's ability to incentivize renewable power generation, and the Wisconsin League of Conservation Voters argued that the legislation would reduce the development of instate renewable power production (Wisconsin Ethics Commission, 2010b). 
Table 8: Lobbying support for 2009 Wisconsin Act 406

\begin{tabular}{|l|c|c|c|c|}
\hline \multicolumn{1}{|c}{ Stakeholder } & Support & \multicolumn{1}{c|}{ Oppose } & Undisclosed/Other & Total \\
\hline Economic Development & 6 & 0 & 0 & 6 \\
\hline Labor Union & 3 & 0 & 1 & 4 \\
\hline Utility & 2 & 0 & 4 & 6 \\
\hline Energy Efficiency & 2 & 0 & 0 & 2 \\
\hline Renewable Energy & 1 & 1 & 0 & 2 \\
\hline Forest Products & 1 & 0 & 0 & 1 \\
\hline Other & 1 & 1 & 0 & 2 \\
\hline Consumer Protection & 0 & 0 & 1 & 1 \\
\hline Environmental & 0 & 4 & 1 & 5 \\
\hline Total & 16 & 6 & 7 & 29 \\
\hline Source: Wisconsin Ethics Commission (2010b) &
\end{tabular}

However, for many groups, the state's push for power and heat production from forestland caused concern. Despite the overall goal of using woody biopower to reduce greenhouse gas emissions and prevent climate change, many conservation groups were concerned that industrial scale woody biopower production would incentivize unsustainable forestry harvesting. In 2009, the state released the "Wisconsin's Forestland Woody Biomass Harvesting Guidelines" for loggers, forest managers and landowners in response to concerns that aggressive biomass harvesting could lead to an adverse effect(s) to forest-based ecosystem services. Guidelines were drafted by the Wisconsin Council on Forestry in partnership with the state's Department of Natural Resources, a stakeholder advisory committee, and a panel of expert reviewers (Herrick et al., 2009). The primary purpose of the non-mandatory guidelines was to minimize the industry's impact on a) biodiversity conservation, $b$ ) soil nutrient depletion, c) physical properties of soil, and water quality. While 
noncompulsory, the guidelines offered standards and best practices related to woody debris retention on the forest floor, biomass offtake instructions based on soil quality, protection of endangered species' habitats, and biomass removal after severe disturbances like wildfires.

\subsubsection{1 - 2015: Dismantling through Tinkering}

The most recent period of legislation can best be described as a series of policy tinkering, which dismantled institutional incentives for renewable energy generation and stretched the policy mix to include the goal of cost-effective electricity production and energy exportation. These policies altered the policy mix's settings, which allowed utilities to comply with RPS requirements through alternative means such as heat production or imports of power generated outside of Wisconsin, and this reduced the demand for in-state power produced from woody biomass. These changes came during a period of "energy excess". By the summer of 2011, some Wisconsin utilities had become energy exporters due to generating capacity exceeding demand. The WPSC then identified this opportunity to use this source of revenue to reduce Wisconsin electric rates and prioritized addressing barriers to energy exports by focusing on increasing transmission capacity and decreasing transmission costs (Wisconsin Public Service Commission, 2012a).

In 2011, all three branches of Wisconsin state government returned to Republican control, most notably with the election of Gov. Scott Walker (R). With that partisan change, several additional policies have led to a weakening of the 
state's RPS and its goal of in-state renewable electricity generation, reflecting the capacity of electoral competition to drive institutional change through the introduction of new ideological preferences (Beland, 2007; Hacker, 2004; Kay, 2007; Petek, 2018). Act 32 of the 2011 legislative session dismantled the WOEI and absorbed some of its responsibilities into the DOA and State Energy Office (Johnson, 2013). The reorganization was categorized as an effort to enhance government efficiency while requiring the DOA to develop the state's energy strategy to promote economic growth while balancing cost-effectiveness, reliability and environmental concerns (Content, 2011).

Passed during the same legislative session, Act 34 tinkered with the RPS definition of qualified renewable sources (instrument setting) to include electricity produced from hydroelectric facilities equal to or greater than $60 \mathrm{MW}$ if the facility was built after December 31 ${ }^{\text {st }}, 2010$ (2011 Wisconsin Act 34, 2011). Act 34, known as the Manitoba Hydro Bill, was passed with the intent of lowering the utilities' cost of meeting RPS requirements by accessing large hydro resources in Manitoba, Canada (Anthony, 2012). Like the creation of credits from non-electric sources established in Act 406 of 2009, the Manitoba Hydro Bill helped to remove incentives for the development of in-state renewable generation by giving utilities the option to procure electricity from outside the state. In-state renewable power producers were now competing against large-scale, cost-effective hydro power from Canada.

Act 34 became legislation despite opposition from many of the key stakeholders in the original RPS expansion legislation (Act 141). According to 
lobbying records, environmental groups such as the Sierra Club and Wisconsin League of Conservation Voters opposed the bill. But unlike Act 406, several renewable energy advocates such as RENEW Wisconsin \& the Wisconsin Solar Energy Industries Association, and consumer protection and energy efficiency groups also opposed the addition of large hydro to satisfying the RPS requirements (Wisconsin Ethics Commission, 2012). Only four groups indicted lobbying support for the bill: Brown County Citizens for Responsible Wind Energy (renewable energy); Wisconsin Manufacturers and Commerce (economic development), Wisconsin Paper Council (forest products), and the Wisconsin Public Service Corporation (utility) with many utility groups abstaining for expressing support or opposition. Table 9 provides a breakdown of support by various lobbying interest groups for Act 34. Despite the limited number of supporting organizations, the majority of lobbying hours were committed by two entities: Manitoba Hydro (hydro power provider) and the Wisconsin Public Services Corporation (utility), which committed 185 and 175 hours respectively of the total 538 total lobbying hours reported on the legislation. Manitoba Hydro refrained from officially supporting or opposing the Act; however, the organization argued that the existing RPS framework unfairly discriminated against Manitoba hydro power (Wisconsin Ethics Commission, 2012). 
Table 9: Lobbying support for 2011 Wisconsin Act 34

\begin{tabular}{|l|c|c|c|c|}
\hline \multicolumn{1}{|c}{ Interest Group } & Support & Oppose & Undisclosed/Other & Total \\
\hline Economic Development & 1 & 0 & 0 & 1 \\
\hline Renewable Energy & 1 & 3 & 1 & 5 \\
\hline Forest Products & 1 & 0 & 0 & 1 \\
\hline Utility & 1 & 0 & 4 & 5 \\
\hline Energy Efficiency & 0 & 1 & 0 & 1 \\
\hline Other & 0 & 0 & 1 & 1 \\
\hline Consumer Protection & 0 & 1 & 0 & 1 \\
\hline Environmental & 0 & 3 & 0 & 3 \\
\hline Total & 4 & 8 & 6 & 18 \\
\hline Source: Wisconsin Ethics Commission (2012) & & \\
\hline
\end{tabular}

The Walker Administration's tinkering further dismantled the state's RPS in 2014 when the state legislature passed the 2013 Wisconsin Act 290. The Act reduced the 2015 statutory RPS requirements for four small utilities that had achieved higher than required proportions of renewables in 2014 under the goal of reducing the cost of RPS implementation (DeLong, 2014). Prior to Act 290, electric providers were required to sell an amount of electricity from renewable sources $6 \%$ above its established baseline (the average amount of electricity from renewable sources that the electric provider sold in 2001, 2002, and 2003) by 2015. Act 290 established that electric providers, who had a baseline greater than $12 \%$ and sold more than 14\% of its total sales from renewable sources in 2014, must sell in 2015 only $2 \%$ of its total sales from renewables (not the original $6 \%$ ) above its baseline. This decreased requirement held constant for the years following 2015 as well (2013 Wisconsin Act 290, 2013). As Table 10 shows, Act 290 experienced broad support from utilities, labor unions, economic development groups and also included the 
Wisconsin Paper Council (Wisconsin Ethics Commission, 2014a). The only opposition came from the Sierra Club, with other renewable energy and environmental groups abstaining from registering an official position.

Table 10: Lobbying support for 2014 Wisconsin Act 290

\begin{tabular}{|l|c|c|c|c|}
\hline \multicolumn{1}{|c|}{ Interest Groups } & Support & Oppose & Undisclosed/Other & Total \\
\hline Utility & 8 & 0 & 1 & 9 \\
\hline Labor Union & 6 & 0 & 0 & 6 \\
\hline Economic Development & 2 & 0 & 0 & 2 \\
\hline Forest Products & 1 & 0 & 0 & 1 \\
\hline Environmental & 0 & 1 & 1 & 2 \\
\hline Health & 0 & 0 & 1 & 1 \\
\hline Renewable Energy & 0 & 0 & 3 & 3 \\
\hline Consumer Protection & 0 & 0 & 1 & 1 \\
\hline Total & 17 & 1 & 7 & 25 \\
\hline Source: Wisconsin Ethics Commission (2014a) \\
\hline
\end{tabular}

Finally, the passage of the 2013 Wisconsin Act 300 required that WPSC allow non-electric credits (e.g. displaced heat production from renewable sources) from sources established before the passage of the 2009 Wisconsin Act 406. This tinkering effort further reduced the need for utilities to acquire renewable generated electricity as it allowed large industrial entities like paper mills to generate revenue from long standing practices such as burning mill residues to produce heat for industrial operations (Lovell, 2014). By tapping into a large source of non-electric credits, incentives for large utilities to purchase renewable energy was further reduced. As Table 11 shows, this policy was widely supported by utility, labor, and economic development interest groups. However, the Wisconsin Paper Council, 
which supported the bill, reported the most lobbying hours (60 out of a total of 157 hours committed to the bill) (Wisconsin Ethics Commission, 2014b).

Table 11: Lobbying support for 2013 Wisconsin Act 300

\begin{tabular}{|l|c|c|c|c|}
\hline \multicolumn{1}{|c|}{ Interest Groups } & Support & Oppose & Undisclosed/Other & Total \\
\hline Utility & 7 & 0 & 2 & 9 \\
\hline Labor Union & 6 & 0 & 0 & 6 \\
\hline Economic Development & 2 & 0 & 0 & 2 \\
\hline Forest Products & 1 & 0 & 1 & 2 \\
\hline Environmental & 0 & 1 & 1 & 1 \\
\hline Renewable Energy & 0 & 1 & 2 & 3 \\
\hline Consumer Protection & 0 & 0 & 1 & 1 \\
\hline Total & 16 & 2 & 7 & 24 \\
\hline Source: Wisconsin Ethics Commission (2014b) \\
\hline
\end{tabular}

\subsection{Discussion}

The case study of Wisconsin's woody biopower policy mix over the past two decades highlights the complex, and often contradictory nature of state renewable power policy development. Exogenous factors such as shifts in technology, regional and international power supply and woody products markets, and macroeconomics clearly play a role in both policy problem definitions and the identification of potential policy solutions. However, endogenous factors, like policy goals and existing institutions shaped the extent to which they developed policies to support woody biopower development. In this section, I discuss key findings from the case study of Wisconsin's RPS including the introduction of a new policy dismantling theory I refer to as "policy dilution." 


\subsubsection{Dismantling the RPS thought Policy Dilution}

By 2009, evidence of policy 'dismantling' through a reduction in policy intensity (Bauer \& Knill, 2014) was demonstrated by the passage of multiple bills aiming to reduce the cost of RPS compliance and ultimately undercut the policy support for biopower production and renewable energy production. The existing policy mix by 2009 was developed under a series of goals that attempted to maximize the benefits of renewable energy such as climate change mitigation, reliability, energy independence, and job growth. The RPS was established and increased as renewable energy production became a priority in Wisconsin. Beginning in 2009, the goal of affordable, cost-effective energy sources and RPS compliance entered the mix and renewable power generation (at the time) was not perceived as the least costly source of electrical power.

Act 406 of 2009 and Act 34 of 2011 changed the nature of the RPS and broadened the eligible sources of renewable energy under the goal of cost effectiveness. By recalibrating the RPS, the Acts expanded the instrument's focus to include both electricity and heat production. It also broadened the instrument's settings to include non-Wisconsin sources of renewable electricity-a deviation from early policies' focus on in-state power production to ensure power reliability. Both calibrations, driven by the goal of cost reductions, reduced the amount of in-state renewably generated electricity that utilities needed to procure. Unlike other forms of policy dismantling discussed in literature, these policy alterations reduced the RPS's ability to meet its goal by adding or expanding eligible activities - a process I 
refer to as "policy dilution". By making these changes, the policy mix's capacity to enhance in-state power production was diminished. The net result was a cumulative reduction in RPS-required in state power production which reduced the potential demand for renewable power from sources such as woody biomass.

Dismantling by dilution, which is a process where layers are added to the policy mix to reduce its capacity to achieve policy goals, helps elected officials circumnavigate one of the primary barriers to traditional policy dismantling: policy taker opposition. The term 'policy taker' refers to a group of people who benefit from, or has their interests advanced by, a policy. During policy dismantling, policy takers are a prime source of opposition as they are likely to clash with any policy change that threatens the status quo and disrupts the policy's ability to continue providing these benefits (Bauer et al., 2012). In the case of the Wisconsin RPS, policy makers added new policy takers (e.g. papermills who could financially benefit from credits generated from their heat and power production) without directly threatening the benefits of existing policy takers (e.g. environmental groups, renewable energy advocates, etc.) while decreasing the power utilities regulatory burden. This helped politicians reduce the intensity of the RPS requirements while building a coalition of supporters under the goal of more affordable energy. This allowed officials to take credit for the policy change and avoid the threat of public blame since active dismantling strategies were not employed.

The case of Wisconsin's RPS demonstrates the role of policy tinkering as a tool for policy dilution. Tinkering, which refers to the adjustment of instrument 
settings and implementation methods, is an incremental process used in policy design to improve an existing policy mix's capacity to achieve desirable outcomes (Weimer, 1993). By adjusting the RPS' settings, such as the definition of eligible renewable power sources and the creation of renewable heating credits, policymakers were able to alleviate the regulatory pressures on power utilities to meet RPS requirements. However, it is important to recognize that expansion in definitions is what makes the dilution process unique. If instead, policymakers chose to tinker with the RPS settings and reduce the formal percentage of required renewable power sales, this would represent the use of an 'active dismantling' strategy exposing policy makers to blame from RPS supporters and beneficiaries (Jordan et al., 2013).

In addition to dilution dismantling strategies, policy makers utilized more traditional dismantling approaches. Act 290 followed the form of "active dismantling" by directing reducing the settings of the RPS by cutting back renewable requirements for some utilities. In contrast Act 32, which eliminated WOEI, was a form of dismantling by arena shifting as its responsibilities were reassigned to the DOA. The state's low RPS target of $10 \%$ for investor-owned utilities' renewable power supply also follows the form of dismantling by default since the costs of renewable energy technologies are rapidly declining. Neighboring midwestern states such as Minnesota have RPS targets as high as $26.5 \%$ by 2025 for most regulated utilities and Illinois has passed an RPS standard of 25\% by 2026 (DSIRE, 2015). By holding constant their RPS standard at a $10 \%$ target set in 2005 , policy makers in Wisconsin have limited its substantial intensity given the context of today's 
sociotechnical environment. All these policies were enacted with the intent of reduced RPS compliance cost and subsequent electricity costs. Essentially, the pursuit of affordable energy re-routed the RPS away from enhancing new in-state renewable electricity generation without wholesale changes to the overall policy mix.

While the concepts of dismantling by default and policy drift significantly overlap, drift and dilution are quite different. Where policy drift refers to the process of policymakers holding policy mix elements constant, which reduces the policy mix's intensity (inaction), dilution is an active dismantling process. Through dilution efforts, policymakers add policy layers or tinker with existing policy settings in an effort to reduce the mix's capacity to achieve desirable policy outcomes. The U.S' federal minimum wage is often cited as an example of policy drift because the minimum wage isn't linked to changes in inflation (Hacker, 2004). When policymakers fail to adjust the minimum wage during periods of price inflation, the federal policy's effectiveness is reduced because it was intended to allow workers to achieve a minimum standard of living. Rising inflation reduces this standard of living by decreasing the minimum wage's purchasing power, thus the policy status quo (inaction) results in less effective policy. In contrast, policymakers seeking to dilute this policy could expand how employers meet their obligations for the federal minimum wage. An example would be altering the definition of hourly wages to include the value of employer provided employee benefits (e.g. sick leave, vacation time, health care, etc.). By including the value of benefits as a means to meet the minimum wage requirements, this could allow employers to offer lower hourly 
salaries (e.g. $\$ 6.50$ per hour) in exchange for additional employee benefits (e.g. sick leave, vacation time, etc.). This change would reduce the policy's capacity to provide workers with a minimum standard of living without actually reducing the minimum wage.

\subsubsection{The Role of Actors: Complexity in the Forest Products Industry and Absence of Woody Biopower Actors}

As the analysis of lobbying records reflects, the development and evolution of the RPS and overall policy mix failed to attract substantial support from actors with the intent of supporting woody biopower production. As previous studies show, successful bioenergy projects require the support of multiple stakeholders across the supply and production chain and at both local and regional scales (Pehlken et al., 2015). The lack of support is a barrier, but it also showcases the potential breadth of stakeholders that could be engaged to develop coalitions to advocate for supportive woody biopower policies.

The forest product industry, the group with the closest ties to woody bioproduction, did not act in concert to this form of energy development, and this lack of industry consensus helps to explain why the policy mix's capacity to support woody biopower production eroded after 2009. Unlike other groups of policy actors, such as utilities, economic development groups, and labor unions, which consistently lobbied after 2005 to dismantle the RPS, and other renewable energy groups like solar and wind advocates who often lobbied against the dilution of the RPS, the 
forest products industry often failed to take a definitive policy stance or took contradictory policy positions. The forest products industry actors often supported efforts to dismantle the RPS, which had the effect of undercutting policy support for in-state woody biopower production while also supporting policies to make woody biopower production cheaper. The Wisconsin Paper Council supported both Manitoba Hydro Bill (Act 34 of 2011) and the cap to RPS renewable energy requirements outlined in Act 290 of 2014. Greenwood Fuels, a producer of fuel pellets, supported Act 406 of 2009 and Act 300 of 2013 to expand RPS credits to heat production from renewable resources. Each of these policies was focused on reducing the cost of utility compliance with the RPS and the general question of electric power affordability. Alternatively, the passage of Act 269 of 2009, which provided tax credits and grants to reduce the cost of woody biomass production for power and heat production, was supported by Plum Creek Timber Company and Timber Producers Association of Michigan \& Wisconsin.

A potential explanation for this lack of coherency in policy support can be made based on where stakeholders are found in the forest industry supply chain and how that impacts policy goals of individual actors. Paper producers, represented by the Wisconsin Paper Council and found at the end of the forest products supply chain, benefit from cheaper power costs and the potential to generate revenue by selling RPS credits generated by heat production within their operations.

Greenwood Fuels, also at the end of the supply chain, also directly benefits from the sale of wood pellets to supplement heat production. Plum Creek Timber Company 
and Timber Producers Association of Michigan \& Wisconsin, which fall at the beginning of the supply chain, potentially benefit from any policy that increases the demand for wood products including woody biopower production. These two actors did not report lobbying efforts for any of the policies that directly affect the RPS; but they did lobby on behalf of Act 269, which provided incentives to reduce operating cost for biomass production from Wisconsin forests. This suggests that policy instruments focusing on biomass production, the beginning of the supply chain, may have more success attracting policy supporters.

What is missing from the lobbying efforts during this period is an actor(s) representing the interest of woody biopower production. As Beland (2007) explains, institutional change (and presumably the lack thereof) is influenced by the strategic maneuverings of actors motivated by their own goals, causal beliefs and assumptions. These beliefs and assumptions shape how actors perceive and define societal problems, and the selection and application of various policy instruments to address these problems. They also serve as a frame from which actors generate policy alternatives and policy support from stakeholders (Béland, 2005). Without the involvement of actor(s) representing the woody biopower industry's interests, other competing policy paradigms likely dominate the policy discussion and frame the direction of institutional change and/or stability. 


\subsubsection{Smart Policy Design}

Acts 269, 401 and 406, along with the new woody biomass harvesting guidelines, reflect a brief policy period in which legislators strove to implement policies intent on supporting the production of energy from the state's substantial forest resources. This round of policies can be described a "smart policy design" by specifically addressing the institutional barriers of biomass power production as outlined by Costello and Finnell (1998). Use of financial policy instruments in Act 269 to decrease the costs of equipment for biomass harvesting helped to remove financial and infrastructure barriers. Act 401 addressed financial and infrastructure constraints through enhanced research funding and subsidized grants and loans for conversion facilities as well as perceptual barriers by establishing the Wisconsin Bioenergy Council. The passage of Act 406 further decreased regulatory barriers by expanding the RPS to include new wood-related sources, and the introduction of voluntary woody biomass harvesting guidelines helped to mitigate negative public perception of the industry's impact on forest sustainability. All combined, these policies show a concerted effort to help reduce the overall cost of wood-based bioenergy production as well as establish new energy markets.

\subsubsection{RPS and the Energy Priorities List: Tense Layering}

The creation of the Energies Priorities List in 1993 institutionalized a preference of domestic renewable generation sources, such as woody biopower, over fossil fuel sources. Although stipulations were put in place that required the WPSC to take 
costs into account, the passage of Act 414 established a policy feedback mechanism for the woody biopower industry that helped to incentivize the use of non-fossil fuel sources (Thelen, 1999). Here, the policy goal intended to capitalize on the environmental and economic benefits of renewable power production. The passage of the 1997 Electric Reliability Act introduced the goal of electric reliability and helped established a clear mandate for woody biopower.

However, passage of Act 141 in 2005 highlights that seemingly congruent policy mixes can lack 'goodness of fit' (Howlett \& Rayner, 2013). The combination of an RPS and the WPSC's Energy Priorities List created an environment in which utilities could potentially meet their renewable energy sales obligations yet still be required to build out more renewable generation thus going beyond Act 9's obligations - an example of tense layering (Kay, 2007). It was argued that this placed an unnecessary burden on utilities and regulators and lawmakers argued for an elimination of the Energy Priorities List (La Follette, 2004). This perceived incongruence ultimately led lawmakers to pass Act 141 in 2005, which eliminated the Energy Priorities List, resulting in the enhanced RPS as Wisconsin's primary means to increase in-state renewable energy generation.

This decision also serves as a pivotal juncture for the state's woody biopower policy mix. Although Act 141 enhanced the overall amount of renewable power sold in Wisconsin, it removed the primary policy mechanism available to the state to directly enforce in-state renewable power generation despite the Act's stated goals of reducing out-of-state energy sources and reducing the need for fossil fuel power. 
Moving forward, the state chose less coercive means to enhance in-state woody biopower generation using subsidies, organization, and information policy tools. Acts 20, 269, and 401 added additional policy layers that can be classified as 'consistent', meaning that they helped to reinforce the primary goal of in-state power generation and subsequent goals like economic development and energy independence (Howlett \& Rayner, 2013). While it can be argued that the RPS mandates are on the coercive end of the policy spectrum, the elimination of the Energy Priority Law eliminated the state's ability to directly steer the type of resource used for electricity generation, leaving it up to the utilities' discretion.

\subsection{Conclusion}

The case study of Wisconsin's RPS highlights the influence of shifting endogenous goals on the state's policy mix and its capacity to promote renewable power generation from sources such as woody biomass. Between the period of 1993 and 2015, policymakers' willingness and rationale for using coercive policy instruments such as renewable energy mandates declined as electric power reliability and climate change mitigation goals took a back seat to energy affordability and compliance cost reduction. These goals were introduced, in large part, because of the introduction of new policy paradigms after fiscal conservatives took control of all three branches of state government. Despite an early period of constructive policy layering that, by all appearances, was conducive to in-state renewable power production, more recent dismantling efforts have undermined the policy mix's support of in-state renewable 
electricity generation. This resulted in a policy mix conducive for renewable energy sales but weakened incentives to produce that power in-state. Exacerbated by internal goal division of the forest products industry, support for woody biopower production failed to substantially materialize.

This insight, afforded using a historical institutionalism lens, provides some clarity when evaluating the tumultuous and often murky world of state energy policy. By identifying when and why policy layers are introduced (or removed), we can understand the conditions of significant policy change. However, the approach used in this paper only reveals the most visible layers of policymaking. By using news articles, legislative memos and databases, this paper was able to understand the publicly-stated goals of relevant legislation and policy instruments; however, it is well known that the motivations for policy action aren't always featured in news headlines, particularly when that change is initiated by groups with enhanced access to policy decision makers (Cobb et al., 1976). To gain a fuller understanding of policy change and the drivers of policy change, a better accounting of the overall power structure of the policy environment is needed (Hall, 1993). Nonetheless, this study provides insight into how previous policy layers are critical to understanding the current policy mix influencing the state's woody biopower industry. 


\subsection{References}

1993 Wisconsin Act 414. (1994). 1993 Assembly Bill 701.

1999 Wisconsin Act 9. (1999). 1999 Assembly Bill 133.

2005 Wisconsin Act 25. (2005). 2005 Assembly Bill 100.

2005 Wisconsin Act 141. (2006). 2005 Senate Bill 459.

2007 Wisconsin Act 20. (2007). 2007 Senate Bill 40.

2009 Wisconsin Act 269. (2010). 2009 Assembly Bill 749.

2009 Wisconsin Act 401. (2010). 2009 Senate Bill 279.

2009 Wisconsin Act 406. (2010). 2009 Senate Bill 273.

2011 Wisconsin Act 34. (2011). 2011 Senate Bill 81.

2013 Wisconsin Act 290. (2013). 2013 Assembly Bill 594.

Abrams, J., Becker, D., Kudrna, J., \& Moseley, C. (2017). Does policy matter? The role of policy systems in forest bioenergy development in the United States. Forest Policy and Economics, 75, 41-48.

Aguilar, F., \& Saunders, A. (2010). Policy instruments promoting wood-to-energy uses in the continental United States. Journal of Forestry, 108(3), 132-140.

Aguilar, F. X. (2015). Wood energy in developed economies: An overlooked renewable. Resources for the Future, (188), 20-27.

Aguilar, F. X., \& Saunders, A. (2010). Policy instruments promoting wood-to-energy uses in the continental United States. Journal of Forestry, 108(3), 132-140.

Aguilar, F. X., Song, N., \& Shifley, S. (2011). Review of consumption trends and public policies promoting woody biomass as an energy feedstock in the U.S. 
Biomass and Bioenergy, 35(8), 3708-3718. doi:

http://dx.doi.org/10.1016/j.biombioe.2011.05.029

Anthony, J. (2012). Legislators are exporting wind energy jobs. BizTimes Milwaukee. Retrieved from http://www.biztimes.com/article/20110620/BLOGS/306209993/

Bauer, M. W., Green-Pedersen, C., Héritier, A., \& Jordan, A. (2012). Dismantling public policy: Preferences, strategies, and effects: Oxford: Oxford University Press.

Bauer, M. W., \& Knill, C. (2014). A conceptual framework for the comparative analysis of policy change: Measurement, explanation and strategies of policy dismantling. Journal of Comparative Policy Analysis: Research and Practice, 16(1), 28-44.

Baumgartner, F., \& Jones, B. (1993). Agendas and Instability in American Politics. : Chicago: University of Chicago Press.

Baumgartner, F. R., \& Jones, B. D. (1991). Agenda dynamics and policy subsystems. The Journal of Politics, 53(04), 1044-1074.

Becker, D., Moseley, C., \& Lee, C. (2011). A supply chain analysis framework for assessing state-level forest biomass utilization policies in the United States. Biomass and Bioenergy, 35(4), 1429-1439.

Beland, D. (2007). Ideas and institutional change in social security: Conversion, layering, and policy drift. Social Science Quarterly, 88(1), 20-38. 
Béland, D. (2005). Ideas and social policy: an institutionalist perspective. Social Policy \& Administration, 39(1), 1-18.

Burns, C. (2012). How and when did we get here? An historical institutionalist analysis of EU biotechnology policy. Journal of European Integration, 34(4), $341-357$.

Center for Resource Solutions. (2000). RPS Case Study (pp. 1-34).

Cobb, R., Ross, J.-K., \& Ross, M. H. (1976). Agenda building as a comparative political process. The American Political Science Review, 70(1), 126-138.

Content, T. (2011). Walker budget proposal would eliminate Office of Energy Independence. Milwaukee-Wisconsin Journal Sentinel. Retrieved from http://www.jsonline.com/business/117446488.html

Costello, R., \& Finnell, J. (1998). Institutional opportunities and constraints to biomass development. Biomass and Bioenergy, 15(3), 201-204.

David, M. (2017). Moving beyond the heuristic of creative destruction: Targeting exnovation with policy mixes for energy transitions. Energy Research \& Social Science, 33, 138-146.

DeLong, K. (2014). Gov. Scott Walker signs 55 bills into law at State Capitol. Fox6now. Retrieved from http://fox6now.com/2014/04/16/gov-scott-walker$\underline{\text { signs-55-bills-into-law-at-state-capitol/ }}$

DSIRE. (2015). Renewable Energy Standard: Program Overview. Retrieved March 4, 2017, from NC Clean Energy Technology Center http://programs.dsireusa.org/system/program/detail/2401 
Ebers, A., Malmsheimer, R. W., Volk, T. A., \& Newman, D. H. (2016). Inventory and classification of United States federal and state forest biomass electricity and heat policies. Biomass and Bioenergy, 84, 67-75.

Energy Information Administration. (2017). Net Generation by State by Type of Producer by Energy. (EIA-906, EIA-920, and EIA-923). Retrieved from http:/www.eia.gov/electricity/data/state/.

Feindt, P. H., \& Flynn, A. (2009). Policy stretching and institutional layering: British food policy between security, safety, quality, health and climate change. British Politics, 4(3), 386-414.

Flaherty, M. (2012). Powr Up! Retrieved March 4, 2018, from https:/www.badgerinstitute.org/WI-Magazine/Volume-21No3/Power$\underline{\text { Up.htm }}$

Goerndt, M. E., D’Amato, A. W., \& Kabrick, J. M. (2014). Forest management for sustainable wood energy feedstock supply. In F. X. Aguilar (Ed.), Wood Energy in Developed Economies: Resource Management, Economics and Policy (pp. 93).

Gravey, V. (2016). The end of a closer, greener European Union? learning from policy dismantling attempts from Delors to Barroso. University of East Anglia, UK, paper prepared for the 2016 UACES SF Conference, London. Hacker, J. S. (2004). Privatizing risk without privatizing the welfare state: The hidden politics of social policy retrenchment in the United States. American Political Science Review, 98(2), 243-260. 
Hacker, J. S., Thelen, K., \& Pierson, P. (2013). Drift and conversion: Hidden faces of institutional change. Paper presented at the 2013 American Political Science Association Annual Meeting, Chicago.

Hall, P. A. (1993). Policy paradigms, social learning, and the state: the case of economic policymaking in Britain. Comparative Politics, 25(3), 275-296.

Herrick, S., Kovach, J., Padley, E., Wagner, C., \& Zastrow, D. (2009). Wisconsin's forestland woody biomass harvesting guidelines. WI DNR Division of Forestry and Wisconsin Council on Forestry, Madison, WI.

Howlett, M., \& Rayner, J. (2013). Patching vs packaging in policy formulation: Complementary effects, goodness of fit, degrees of freedom, and feasibility in policy portfolio design. Annual Review of Policy Design, 1(1), 1-19.

Johnson, R. (2013). Department of Administration's Energy Services. (Informational Paper 89).

Jordan, A., Bauer, M. W., \& Green-Pedersen, C. (2013). Policy dismantling. Journal of European Public Policy, 20(5), 795-805.

Jordana, J. (2014). Multiple crises and policy dismantling in Spain: Political strategies and distributive implications. Political Studies Review, 12(2), 224238.

Kay, A. (2007). Tense layering and synthetic policy paradigms: The politics of health insurance in Australia. Australian Journal of Political Science, 42(4), $579-591$. 
Kern, F., Kivimaa, P., \& Martiskainen, M. (2017). Policy packaging or policy patching? The development of complex energy efficiency policy mixes. Energy Research \& Social Science, 23, 11-25.

La Follette, D. (2004). Report of the Governor's Task Force on Energy Efficiency \& Renewables: Department of Administration, State of Wisconsin.

Lantiainen, S. M., Song, N., \& Aguilar, F. X. (2014). Public policy promoting wood energy in the EU and US. In F. X. Aguilar (Ed.), Wood Energy in Developed Economies: Resource Management, Economics and Policy (pp. 189-222).

Luzadis, V. A., Volk, T. A., \& Buchholz, T. S. (2008). Using a systems approach to improve bioenergy sustainability assessment. In B. D. Solomon \& V. A. Luzadis (Eds.), Renewable Energy from Forest Resources in the United States. New York, NY: Routledge, 196-210.

Mahoney, J., \& Thelen, K. (2010). A theory of gradual institutional change. In J. Mahoney \& K. Thelen (Eds.), Explaining Institutional Change: Ambiguity, Agency, and Power. New York, NY: Cambridge University Press, 1-37.

Nelson, T., \& Thilly, R. (2008). Wisconsin's Strategy for Reducing Global Warming. Madison, WI: Department of Natural Resources and Public Service Commission of WIsconsin.

Pehlken, A., Madena, K., Aden, C., \& Klenke, T. (2015). Forming stakeholder alliances to unlock alternative and unused biomass potentials in bioenergy regions. Journal of Cleaner Production, 110, 66-77. 
Petek, A. (2018). The layering of disability policy: The case of Croatia. Teorija in Praksa, 55(1), 161.

Pierson, P., \& Skocpol, T. (2002). Historical institutionalism in contemporary political science. Political science: The state of the discipline, New York, NY: Norton, p. 3.

Radloff, G., Du, X., Porter, P., \& Runge, T. (2012). Wisconsin Strategic Bioenergy Feedstock Assessment. Retrieved from https://energy.wisc.edu/sites/default/files/pdf/WI_Strategic_Biomass_Assess ment_WEB.pdf.

Ritsche, D. F. (1998). Legislative Briefs: The Electric Repliability Act. (Brief 98-7).

Rocco, P., \& Thurston, C. (2014). From metaphors to measures: observable indicators of gradual institutional change. Journal of Public Policy, 34(1), 3562.

Rogge, K. S., \& Reichardt, K. (2016). Policy mixes for sustainability transitions: An extended concept and framework for analysis. Research Policy, 45(8), 16201635.

Schickler, E. (2001). Disjointed pluralism: Institutional innovation and the development of the US Congress. Princeton, NJ: Princeton University Press.

Steinmo, S. (2014). Historical Institutionalism and Experimental Methods. In O. Fioretos, T. Falleti \& A. Sheingate (Eds.), The Oxford handbook on historical institutionalism. Oxford, UK: Oxford University Press, 107-123. 
Steinmo, S., Thelen, K., \& Longstreth, F. (1992). Structuring politics: historical institutionalism in comparative analysis: Cambridge University Press.

Thelen, K. (1999). Historical institutionalism in comparative politics. Annual Review of Political Science, 2(1), 369-404.

Thelen, K. (2004). How institutions evolve: The political economy of skills in Germany, Britain, the United States, and Japan. New York, NY: Cambridge University Press.

U.S. Energy Information Administration. (2017). How much electricity does an American home use? Retrieved July 29, 2018, from

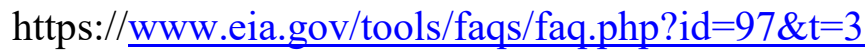

Van der Heijden, J. (2011). Institutional layering: A review of the use of the concept. Politics, 31(1), 9-18.

Weimer, D. L. (1993). The current state of design craft: Borrowing, tinkering, and problem solving. Public Administration Review, 53(2), 110-120.

Wellstead, A., Rayner, J., \& Howlett, M. (2016). Alberta’s oil sands reclamation policy trajectory: The role of tense layering, policy stretching and policy patching in long-term policy dynamics. Journal of Environmental Policy and Planning, 59(10), 1873-1890.

Wisconsin Ethics Commission. (2006). 2005-2006 Legislative Session: Senate Bill 459. https://lobbying.wi.gov/What/BillInformation/2005REG/ Information $/ 3293 ?$ tab $=$ Principals 
Wisconsin Ethics Commission. (2010a). 2009-2010 Legislative Session: Assembly Bill 749. https://lobbying.wi.gov/What/BillInformation/2009REG/Information/ $7391 ?$ tab $=$ Principals

Wisconsin Ethics Commission. (2010b). 2009-2010 Legislative Session: Senate Bill 273. https://lobbying.wi.gov/What/BillInformation/2009REG/Information/ 6699 ?tab=Principals

Wisconsin Ethics Commission. (2010c). 2009-2010 Legislative Session: Senate Bill 279. https://lobbying.wi.gov/What/BillInformation/2009REG/Information/ 6727?tab=Principals

Wisconsin Ethics Commission. (2012). 2011-2012 Legislative Session: Senate Bill 81. https://lobbying.wi.gov/What/BillInformation/2011REG/Information/ 8204?tab=Principals

Wisconsin Ethics Commission. (2014a). 2013-2014 Legislative Session: Assembly Bill 594. https://lobbying.wi.gov/What/BillInformation/2013REG/ Information/10905?tab=Principals

Wisconsin Ethics Commission. (2014b). 2013-2014 Legislative Session: Assembly Bill 596. https://lobbying.wi.gov/What/BillInformation/2013REG/ Information $/ 10907 ?$ tab $=$ Efforts

Wisconsin Public Service Commission. (2012a). Biennial Report 2009-2011. Retrieved from https://doa.wi.gov/budget/SBO/200911\%20155\%20PSC\%20Biennial\%20Report.pdf. 
Wisconsin Public Service Commission. (2012b). Wisconsin Administrative Register No 675: Rules Published with the Register and Final Regulatory Flexibililty Analyses. 


\subsection{Chapter 3 Preface}

In the previous chapter, I showed that the state-level woody biopower policy mix in Wisconsin has experienced policy dismantling, in part, due to a lack of policy support from key stakeholder groups such as the wood products industry. The analysis showed that policy makers' willingness to weaken or eliminate supportive mechanisms in pursuit of cheaper energy has stunted the state's push for in-state renewable power generation and demand for woody biopower. The lack of policy support from key stakeholders signals limited socio-political social acceptance for the woody biopower industry in Wisconsin.

In the following chapter, I explore factors that influence the social acceptance of woody biomass harvesting through the use of a household survey in Tomahawk, WI. Given that many of the negative and positive ecological, economic and social effects of woody biopower production occur during the biomass procurement stage, biomass production communities play a critical role in social acceptance of the industry. The study utilizes an ecosystem services framework approach to better understand how the perceptions of the benefits of local forests influence support for using local forests for electricity production in addition to identifying strategies and policies to develop socially acceptable biomass harvesting practices.

In Chapter Three, I will begin with a review of the bioenergy attitudes and ecosystem service framework literature. This is followed by a description of the survey and data analysis methods used in the study. The results section reviews key findings from the study including respondents' preferences for forest-based biomass 
sources, prioritization of forest-based ecosystem services, and the results of a binomial logistic regression intended to identify key drivers of support for forest based biopower production. The chapter concludes with recommendations for incorporating the ecosystem services framework in scoping socially acceptable biomass harvesting systems as well as policy recommendations for the woody bioenergy industry. 


\section{Chapter 3: Deciphering Support for Woody Biomass Production for Electric Power Using an Ecosystem Service Framework ${ }^{3}$}

A growing literature focuses on measuring the social value of ecosystem services, alongside traditional economic valuations, to inform natural resource management decisions. However, very few studies have explored the role of ecosystem service values in the context of the general public's support for natural resource management decisions. This leaves open the possibility that policy makers and resource managers are relying on criteria that have negligible influence on the public's preferences. In this chapter, I present the results from a household survey of Tomahawk, Wisconsin residents that evaluates respondent's support for woody biomass production for power generation. Results show that respondents in biomass producing communities are more supportive of biomass sources such as forestry residues and forestry thinnings than dedicated energy wood harvesting operations. In addition, the results indicate that using an ecosystem service approach can help explain differences in support between these respondents and provide insight into socially acceptable forms of biomass harvesting operations. These results demonstrate that consideration of public ecosystem service values during policy and project development can help shape socially acceptable forms of woody biomass production and potentially other

\footnotetext{
${ }^{3}$ The material contained in this chapter is in preparation for re-submission to the Ecosystem Services.
} 
forms of land use decisions embodying complex social, economic and environmental tradeoffs.

\subsection{Introduction}

Experts on climate change have concluded with a high degree of certainty that the fossil fuel combustion is the primary cause of climate change (IPCC, 2014). By 2030, burning coal and natural gas are projected to account for approximately $44 \%$ and $19.3 \%$ of the world's electricity generation, respectively (Birol, 2008) and electricity generation is the number one greenhouse gas emitter (Brown \& Sovacool, 2011). If current global greenhouse gas emission levels continue to go unabated, scientists predict a host of negative consequences including more frequent extreme weather events, rising sea levels threatening coastal populations, destruction of ecosystems and wildlife habitat, changes in global temperatures and precipitation patterns altering food production systems, and more (IPCC, 2007; Reddy et al., 1997). The Intergovernmental Panel on Climate Change predicts that the adoption rate of zero- and low-carbon energy sources such as renewable energy technologies, nuclear, and fossil fuel sources incorporating carbon capture and sequestration (CCS) needs to triple or even quadruple by 2050 to maintain atmospheric concentrations of $450 \mathrm{ppm} \mathrm{CO}_{2}$ eq in order to keep global temperature from rising no more than $2^{\circ} \mathrm{C}$ relative to pre-industrial levels (IPPC, 2014).

Previous studies suggest that the use of woody biomass for bioenergy production can play a significant role in curbing U.S. greenhouse gas emissions by 
reducing the country's reliance on fossil fuels (Downing et al., 2011). Woody biomass can be extracted from forests in the form of residues generated from logging operations, thinning operations to reduce wildfire risks, and dedicated fuelwood harvesting activities; however the use of plantation-style agroforestry practices are increasing in the U.S. (Goerndt et al., 2014). Woody bioenergy projects are often promoted by government policies seeking to mitigate climate change while fostering rural economic growth and energy independence (Lantiainen et al., 2014).

Despite the potential climate change mitigation and economic benefits posited by supporters, forest-based bioenergy is often highly controversial (National Research Council and National Academy of Sciences, 2011). Woody bioenergy production involves tradeoffs (near- and long-term) between several critical ecosystem services (Caputo et al., 2016). This can create conflict between supporters of bioenergy projects and opposition groups who fear forest health is threatened or that bioenergy conversion facilities cause adverse environmental and social health effects. Failure for projects to achieve "social acceptance," or when society deems an option preferable than the status quo, has been identified as one of the primary barriers to successful renewable energy projects (Wüstenhagen et al., 2007).

Increasingly natural resource developers are citing a desire to achieve a "social license to operate" (SLO) as a reason for modifying their businesses practices using input from local communities. The phrase originated in the late 1990s as the result of the global mining industries' efforts to reduce socio-political risks to 
resource development activities (Boutilier et al., 2012). However, the concept has gained traction within the agriculture, forest and energy industries (Moffat et al., 2016). While there is no universally accepted definition of SLO among scholars, it is often linked to constructs such as community acceptance and has been used to describe the increasing demands for private enterprises' accountability to local stakeholders (Lincoln, 2015; Moffat et al., 2016). At a basic level, SLO refers to a commitment from a private enterprise to adhere to social norms while conducting natural resource development activities in exchange for acceptance (or lack of opposition) from community stakeholders (Lincoln, 2015). Inherently, it is an evaluation of business practices based on local standards for how businesses should operate (Gunningham et al., 2004). This represents a recognition by private natural resource developers that non-governmental community stakeholders have the capacity to prevent or halt a project despite the fact that it may meet existing legal and regulatory requirements (e.g. environmental regulations, permits, etc.). In this sense, projects can meet all formal requirements set forth by governing institutions, but a failure to receive a SLO prevents the project from moving forward because of opposition from community stakeholders. This is particularly true in areas in which government institutions are weak or where there is competing land use demands.

Scholars suggest that corporations' adoption of a SLO mindset is being driven by a combination of factors. First, the increased mechanization of natural resource extraction industries has reduced the number of individuals economically benefiting from these projects, undercutting one of the primary motivations for 
communities to support natural resource development (Boutilier et al., 2012). Second, natural resource development projects are perceived as exporting local wealth while leaving communities to receive the negative social, economic and environmental externalities of the extraction process (Boutilier et al., 2012). Without the carrot of large, local employment generation, companies are finding it difficult to foster local socio-political support leading to challenges to long-term property rights, permitting, and increases in restrictive, costly regulations. Third, there has been an increase in the propensity for and intensity of environmental-focused political activism and a generational shift favoring environmental protection (Lincoln, 2015). Industries whose activities generate adverse environmental externalities are generating more public opposition. Fourth, innovations in communication technology and social media are allowing groups to quickly mobilize opposition against local development projects and garner national and international attention in real-time (Gehman et al., 2017; Lincoln, 2015). Finally, a growth in regional and national non-governmental organizations' capacity to mobilize and support local environmental activism is supplying the local opposition with political, financial, and legal resources allowing such groups to more effectively challenge extractive industries (Lincoln, 2015). The cumulative effect is an increase in risk to resource development projects and is putting pressure on corporations to work with local community stakeholders.

Despite its growing popularity among industry, governments and academia, a mutually agreed upon definition of SLO has failed to materialize. Without a clear 
definition, modeling and measuring SLO in case studies has been difficult (Lincoln, 2015). In order to reduce ambiguity and move toward conceptual operationalization, several scholars have proposed various models of SLO theory. In Boutilier et al. (2012)'s 'pyramid model', SLO is suggested to have four levels: rejection, acceptance, approval, identification. Rejection implies that the industry has failed to adequately address local stakeholders' expectations for the project and thus does not receive a SLO. Acceptance refers to when a natural resource developer meets or commits to meeting a minimum standard of operational practices whereby society allows the project to proceed. Approval refers to when trust and support is established between the project developer and stakeholders, which generates a resistance to project criticism and opposition. Identification refers to a stage in which communities' and stakeholders' identities become intertwined with the development project. This is achieved when trust between the project developers and community stakeholders is at a high level and stakeholders perceive that their best interests are tied to the success of the development project. Research results suggest that perceptions of procedural fairness, distributional fairness (equity in cost and benefit distribution), and trust in governance influence stakeholders' willingness to accept industrial extraction processes (Moffat et al., 2016).

A parallel model, referred to as the "three strands model" seeks to explain why some private enterprises exceed environmental regulatory requirements, while others fail to achieve them. The model identifies three types of "licenses" that influence business operations: economic, legal and social (Gehman et al., 2017). 
According to this model, 'economic license' refers to the project's capacity to meet the profitability demands of investors and managers; 'legal license' refers to the regulatory and statutory requirements of the project imposed by traditional governments; and 'social license' refers to the demands of local communities and environmental groups on the project. The research, which was originally developed through a review of 14 pulp mills, suggested that stakeholders such as the media, the public, nongovernmental groups, and community members have the capacity to leverage both legal pressure (e.g. law-suits) and economic pressures (e.g. boycotts) when social license is not granted and helps to explain why some companies chose to exceed regulatory requirements (Gunningham et al., 2004). However, additional research has shown that these pressures alone are not strong enough to motivate businesses to go beyond baseline compliance (Lynch-Wood \& Williamson, 2007). Increasingly, corporations seeking to achieve SLO are required to measure and mitigate their effects on ecosystem services. Government policies are incorporating the value of ecosystem services to maximize the societal benefits of natural resource management and to balance the inherent tradeoffs of managing ecosystems for societal well-being (Bull et al., 2016). Examples include the U.S. National Ecosystem Service Classification System (NESCS) to assist in policy impact analysis for regulatory review (U.S. Environmental Protection Agency, 2015) and ecosystem service valuation guidelines developed by the UK's Department for Environment, Food \& Rural Affairs (U.K. Department for Environment Food and Rural Affairs, 2007). Generally, these policies help set forth expectations and 
parameters for the proper measurement, valuation and accounting of ecosystem services, definition of services and classifications, and guidelines for how to estimate impacts of various land use alternatives on ecosystem services. These policies are often seen as complimentary to traditional policy evaluation criteria and decisionmaking processes.

Most ecosystem service frameworks have relied upon economic valuation tools (Scholte et al., 2015). However, many services values are not well captured using economic measures (Costanza, 2008; Costanza \& Folke, 1997; De Groot et al., 2010). This has led numerous authors to suggest using multiple approaches to ecosystem service valuation (Chan et al., 2012; Costanza, 2008; Spangenberg \& Settele, 2010). Scholars have recognized the need to measure non-monetary valuation in order to understand individuals' actions, including the support for or opposition to natural resource management systems, which affect critical ecosystems such as forests (Asah et al., 2014).

The ecosystem service framework provides a means to both understand the effects of natural resource management systems on human well-being (Gasparatos et al., 2011) as well as why key stakeholders support or oppose woody biomass production. Previous work has shown a correlation between stakeholders' valuation of forest-based ecosystem services and their preferences for forest use (Clement \& Cheng, 2011). Perceptions of ecological impacts and the fairness in costs and benefits distribution of woody energy projects have been shown as key predictors of forest-based bioenergy support (Bronfman et al., 2012; Hitchner et al., 2014). 
Beliefs regarding impacts to ecosystem services of high socio-cultural value help provide the foundation for evaluative beliefs that determine attitudes toward projects like woody biomass harvesting (Heberlein, 2012).

Woody biomass production from forestlands involves many stakeholders such as forestland owners, biomass harvesters and transporters, utilities, regulators, and energy consumers such as the general public and industry. Sociocultural preferences toward the importance and management of ecosystem services will differ across stakeholder groups because values, beliefs and attitudes are diverse (Chan et al., 2012), and natural resource management activities that affect the flows of ecosystem services should be evaluated by stakeholders who depend on local ecosystems (Seppelt et al., 2011). The public plays an important role in woody bioenergy development and can experience a multitude of economic and social effects when forest landscapes are altered. However, very little attention has been paid to this group in the woody bioenergy literature, which often focuses predominantly on feedstock producer participation as a primary means of identifying societal support of the natural resource management system (Chin et al., 2014). The public is crucial as it provides political support to legislators and government executives who craft incentive (or prohibitive) policies for woody bioenergy energy, as well as acting as a powerful opposition force if natural resource projects fail to gain social acceptance (Hitchner et al., 2014).

Few studies have explored the role of ecosystem service values in the context of the general public's support or opposition toward natural resource management 
decisions. This leaves open the possibility that policy makers and resource managers are relying on criteria that has negligible influence on the public's preferences. The intent of this study is to help close the gap in the understanding the public's support or opposition to local forest biomass production for utility-scale electricity

production. The research is intended to answer the following research questions: 1) What factors influence the public's support for woody biomass production?; and 2) How does this level of support change based on the source of woody biomass materials? Understanding the answers to these questions help to identify opportunities to develop best management practices (BMP) that are responsive to the biomass production communities' preferences based on the complex socioeconomic and ecological tradeoffs created by the woody bioenergy production process (SoyMassoni et al., 2016).

\subsection{Materials and Methods}

\subsubsection{Study Area}

The study was conducted in the City of Tomahawk, Wisconsin within the Laurentian Mixed Forest Province, which covers much of the Great Lakes Region (Bailey, 1994). This study area was selected because its residents are affected by woody biomass production to supply a 50 MWe biomass cogeneration facility located 72.4 $\mathrm{km}$ to the south in the Village of Rothschild at the Domtar Rothschild Paper Mill. The power facility is owned by We Energies, a Wisconsin-based investor-owned 
utility, and came online in November 2013 (We Energies, 2013). According to filings with the Wisconsin Public Service Commission, $84 \%$ of biomass fuel was expected to come from logging residues generated during forest harvesting from private non-industrial and county forest lands within $120 \mathrm{~km}$ of the plant (We Energies, 2010). Figure 2 displays the area in which the study took place in addition to the location of the biomass conversion facility's biomass procurement zone. Tomahawk is located in Lincoln County $\left(2,336 \mathrm{~km}^{2}\right)$. Forest is the dominant land cover for the county at $1,851 \mathrm{~km}^{2}$ (National Agriculture Statistics Service, 2015). According to the U.S. Forest Service's Forest Inventory and Analysis National Program estimates, Lincoln County primary forest groups are maple/beech/birch $\left(694 \mathrm{~km}^{2}\right)$, aspen/birch $\left(381 \mathrm{~km}^{2}\right)$, spruce/fir $\left(239 \mathrm{~km}^{2}\right)$, oak/hickory $\left(142 \mathrm{~km}^{2}\right)$, and white/red/jack pine $\left(100 \mathrm{~km}^{2}\right)$ (USFS FIA, 2016). Approximately $408 \mathrm{~km}^{2}$ is designated as County-owned forestland, which generated $\$ 1,973,804.17$ in timber sales revenue in 2015 (Lincoln County, 2015). These forests provide local habitat for ruffed grouse, turkey, bear, deer and other furbearing species and are managed for numerous recreational opportunities such as hiking, cross-country skiing, snowshoeing, horseback riding, bicycling, camping and motorized vehicle recreation (e.g. snowmobiles and ATVs) (Lincoln County, 2015). While most of the county is under forest cover, some agricultural production is located near the county's southern border. 


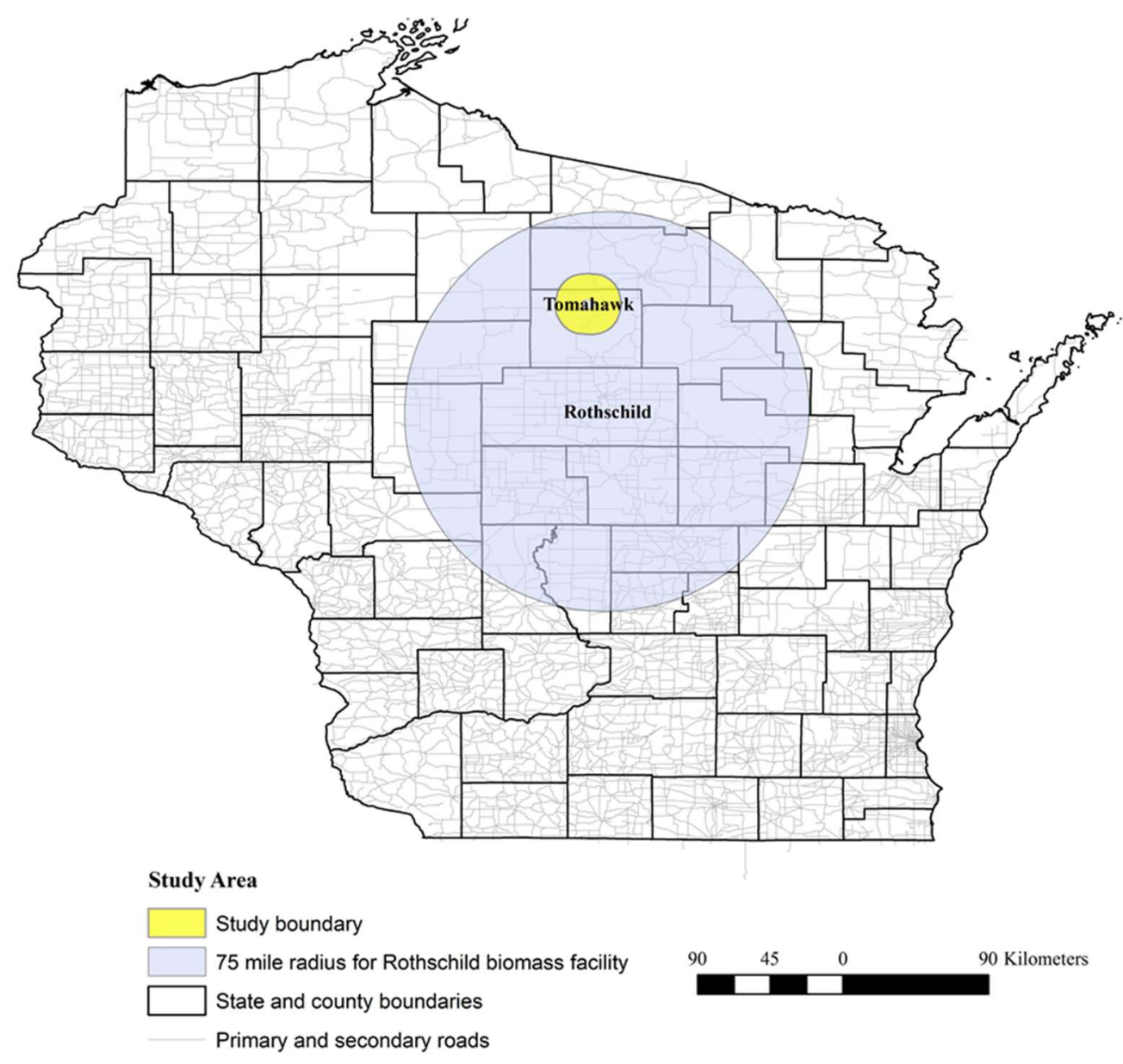

Figure 2: Study area and site of Rothschild biopower facility's biomass procurement zone

\subsubsection{Target Population and Sample Construction}

The study sought to understand the attitudes and perceptions of Tomahawk community members toward local woody biomass harvesting for regional power production. For this study, community members included residents of Tomahawk and residents within a $17 \mathrm{~km}(10$ mile) radius of the community. While proximity does not definitely define a connection to a community, the closer one lives to an 
area increases the likelihood of shared relational connections and interests leading to a stronger sense of community (McMillan \& Chavis, 1986). In addition, individuals outside the city limits were more likely to be potential forestland owners. The distance delimitation was used under the assumption that households living closer to Tomahawk were more likely than those living farther away to identify themselves as members of the Tomahawk community because of location of employment, school systems, friends, family and other social networks.

Demographic data for the study area was used from the 2013 American Community Survey: 5-Year Data (2009-13) and the Minnesota Population Center's National Historical Geographic Information System (v2.0). Using census block group data, the area's population (Tomahawk plus outlying rural area) was estimated at 9,064 residents, with a median income of $\$ 51,058$. For the city of Tomahawk, females comprise $53.8 \%$ of the population with males at $46.2 \%$.

The unit of analysis was the household level. Cluster sampling was used to select sample element groups as opposed to simple random sampling in order to reduce the cost of the drop-off/pick-up survey implementation method. However, using this approach likely results in a design effect that increases the sample's standard error (Groves et al., 2011). Esri ArcGIS 10.2 software was used in combination with 2014 Lincoln County residential address point files, and 2014 property tax parcel vector files for the area were used to construct the sample (University of Wisconsin, 2015). For the general population sample, eight randomly selected "clusters" were generated using the modified 2014 address file. "Clusters" 
were developed by randomly selecting eight household addresses and then selecting additional households within geographic proximity (e.g. the same street, block and neighborhood) to facilitate walking door to door to deliver surveys. General population clusters were limited to within or just outside of Tomahawk's city limits. Given the asymmetric layout of Tomahawk's neighborhoods and variance in population density, the total number of households within a cluster varied dramatically. Higher income neighborhoods often had fewer households compared to lower income areas within the same cluster. On average, each general population cluster consisted of 47 households for a total of 375 households within the initial sample.

Potential forestland owners were selected within a 10 -mile $(17 \mathrm{~km})$ radius from Tomahawk's city limits. Forestland owners were identified using 2014 tax parcel and address point GIS files for Lincoln County. These files were combined with records selected based on the following conditions: 1) parcel sizes were greater than 10 acres; 2) buildings were located on the parcels; and 3) buildings on parcels were classified as "farm", "single family", "apartment or condo", "multi-family" or "mobile home". From this list, four clusters were randomly selected following similar steps described above to over-sample for forestland owners in the area. Using a Wisconsin primary roads vector file, additional nearby households were pulled into the sample for an original sample size of 133 potential forest-owning household participants. The combined original sample size was 508 households. 


\subsubsection{Data Collection}

The study used a door-to-door drop-off/pick-up survey (Steele et al., 2001). The survey was administered over two weeks in July and August, 2015. The study used the "Tailored Design Method" to enhance survey response rates (Dillman et al., 2010). Survey visual design elements included high-resolution colored images, a cover page, larger text font size, and increased white-space surrounding questions. A hand-addressed, personalized pre-notification letter was mailed a week before the survey team of four researchers reached the field. The letter was sent using brightly colored envelopes with affixed stamps and were hand addressed to stand out in the mailbox.

The survey had 27 questions partitioned into nine sections. An example of the survey is included in the Supplemental Documentation section. This survey instrument was used as part of a larger international cross-country comparative study, and as such, some survey sections and questions did not directly apply to this analysis of Tomahawk residents' attitudes toward local woody biomass production.

Part A of the survey collected information on the age of the respondent and length of residency within the Tomahawk community. Part B used two separate measurements to assess the respondent's social valuation of forest-based ecosystem services. The first measure used a five-point Likert-scale matrix to collect data on the respondent's perception of the importance of different forest-based ecosystem services to his or her household. The second measure, based om a mail survey conducted by Sherrouse et al. (2011), asked participants to allocate a hypothetical 
$\$ 100$ among ten different forest ecosystem services in order to ensure that the ecosystem benefits were preserved. Respondents were instructed that the $\$ 100$ could be divided equally among all tens ecosystem services or various amounts could be allocated to identify more highly prioritized services. However, all $\$ 100$ must be "spent". Part C measured respondents' familiarity with wood-based bioenergy, the importance of domestic energy security and local renewable energy utilization. In Part D, respondents were asked how they believed forest biomass harvesting will affect (both positively and negatively) various ecosystem services and socioeconomic systems. Likert scales are used for these questions. Part D also contained the measures of the dependent variable for general support of local biomass production in addition to specific levels of support for different sources of local woody biomass (e.g. thinnings, dedicated harvests, residues). Part E used three five-point Likert scale questions to assess respondents' environmental attitudes. The questions sought to determine the respondent's attitude toward maximizing natural resource utilization for the benefit of humans (anthropocentric values) versus protecting nature for nature's sake (biocentric values) (Kempton et al., 1996). Part F used a Likert-scale question set developed by Johnson et al. (2011) to assess the respondents' beliefs toward climate change. Part G used a series of five-point Likert Scale questions to understand respondents' attitudes toward government's role in local woody bioenergy development. Part $\mathrm{H}$ features a series of questions related to attitudes on commercial and residential scale use of wood but were not used in this analysis. Finally, Part I collected information on age, income, gender, education, 
forest ownership, participation in environmental groups, political attitudes and sources of employment.

\subsubsection{Statistical Analysis}

IBM SPSS Statistics (version 23.0) was used in this study. In the survey, the dependent variable (respondent's support or opposition toward local woody biomass production) was measured at the ordinal level using a five-point Likert scale. This measure was converted into a binary measure of either "support" or "oppose/neutral". Doing so allows the data analysis to interpret the results in order to understand how the study's explanatory variables influence social acceptance of local woody biomass production. Since the dependent variable was binary, a binomial logistic regression was used to estimate the coefficients of the explanatory and control variables used in the model. Independent variables were measured or converted to interval levels or recoded as dummy variables for analysis.

The relationship between dependent and explanatory variables was identified using the following general equation (Peng et al., 2002):

$\operatorname{logit}(Y)=\ln \left(\frac{\pi}{1-\pi}\right)=\alpha+\beta_{1} X_{1}+\beta_{2} X_{2}$

Therefore,

$\pi=$ Probability $\left(\mathrm{Y}=\right.$ outcome of interest $\left.\mid X_{1}=x_{1}, X_{2}=x_{2}\right)=$

$$
P(Y)=\frac{e^{\alpha+b_{1} x_{1}+b_{2} x_{2}+\ldots+b_{n} x_{n}}}{1+e^{\alpha+b_{1} x_{1}+b_{2} x_{2}+\ldots+b_{n} x_{n}}}
$$


where $P$ is the probability of $Y$ occurring, and $e$ is the natural log. The y-intercept is $\alpha$ and $b_{1}$ represents the beta coefficient of $X_{1}$ Backwards stepwise variable removal procedures were used to identify the most parsimonious model.

Principal component analysis was used for the purpose of latent variable identification and data reduction (Miller \& Acton, 2009). In most cases, the study's explanatory and control variables were measured using a series of five-point Likert scale question items. Broad categories such as biomass production effects and ecosystem service social values were reduced to more manageable, “deeper”, variables to reduce the likelihood of inefficient model parameter estimates (King et al., 1994). The study used SPSS' Direct Oblim oblique rotation command and selected factors based on the break point in the Scree Plot display and Eigenvalues greater than 1.0 (Osborne \& Costello, 2009).

SPSS's logistic regression procedure removes cases with missing variable data (listwise deletion). For surveys with large question sets, this has the potential to dramatically reduce the number of cases used in the model's analysis. For the purpose of this study, imputation techniques were used to estimate missing case values. Series means were used to impute missing data (Donders et al., 2006).

\subsubsection{Model and Variable Definitions}

As indicated above, previous studies have shown that a variety of factors influence the general public's support of bioenergy systems. These include bioenergy familiarity, environmental effects, socioeconomic effects, environmental 
consciousness, rural residency, government involvement and demographic characteristics (age, gender, income and education). The primary explanatory variables for this study are respondents' social values of forest-based ecosystem services. The model tested in this study is:

SUPPORT $=f($ ESVALUE, ECON, ACCESS, LANDSCAPE, CARBON, YOUTH, FAMILIARITY, CCBELIEF, SUPPLIER, GOVCAP, AGE, INCOME, GENDER, EDUCATION)

Table 12 summarizes the variable unit definitions and hypothesized coefficient directions. Support for woody biomass production for biopower production (SUPPORT) was the study's dependent variable. It was measured using the statement: "Overall, I support the expansion of using forest materials for electricity production" and was measured using a five-point Likert scale with "1" being "strongly disagree", 5 being "strongly agree" and " 3 " being neutral. Since the study's focus was on factors that influence supporting woody biomass production, the variable was collapsed into "1" for respondents who responded with "strongly agree" or "agree" with the statement expressing support, and respondents who provided an answer of "neutral", "disagree" or "strongly disagree" were coded as " 0 " for lacking support. This created a binary dependent variable suitable for binomial logistic regression.

Ecosystem service values (ESVALUE) was measured for the following 11 forest-based ecosystem services: visually pleasing landscapes, recreation, clean air, carbon storage, clean water, wild foods, firewood, economic opportunities (jobs), 
bird habitat, habitat for pollinators (e.g. bees) and soil quality. Respondents were asked to assess the personal importance of each service using a series of five-point Likert scale questions with " 1 " being "very important" and "5" being "not important at all". The relationship between ecosystem service values and biomass production support is complex, given the nature and variety of ecosystem services provided by forests combined with the respondent's level of ecosystem service awareness and perceptions of biomass productions impacts to those services. Using the Millennial Ecosystem Assessment Framework's four broad categories as a guide, it is hypothesized that individuals who highly value supporting, regulating and cultural services will negatively correlate with SUPPORT, while individuals who highly value provisioning services will positively correlate with SUPPORT (Millennium Ecosystem Assessment, 2005). This assumes that the former group will perceive biomass production as a risk to regulating, supporting and cultural services. The latter group's high value for provisioning services will carry over to biomass production, another forest-based provisioning service. Principal component analysis was used to produce factor scores to reduce the set of 11 question items down to fewer dimensions. Factor scores were exported using the Anderson-Rubin method to reduce the chance that the variable measures correlated with one another. 
Table 12: Definition and hypothesized coefficient direction of variables used in binomial logistic regression model

\begin{tabular}{|c|c|c|}
\hline Variable & Definition Units & Hypothesis \\
\hline SUPPORT & $\begin{array}{l}\text { Level of agreement with the following statement: } \\
\text { "Overall, I support the expansion of using forest materials } \\
\text { for electricity production." } 1 \text { if agree, } 0 \text { if neutral or } \\
\text { disagree }\end{array}$ & $\begin{array}{l}\text { Dependent } \\
\text { Variable }\end{array}$ \\
\hline ESVALUE & $\begin{array}{l}\text { Factor scores of respondent's importance placed on } \\
\text { forest-based ecosystem services }\end{array}$ & varies \\
\hline FAMILIARITY & $\begin{array}{l}\text { Respondent's level of familiarity with forest-based } \\
\text { bioenergy, scale } 0 \text { (low familiarity) to } 6 \text { (high familiarity) }\end{array}$ & positive \\
\hline ECON & $\begin{array}{l}\text { Respondent's belief that forest biomass production will } \\
\text { have a positive impact on the local economy using a five- } \\
\text { point Likert scale, with }-2 \text { being a very negative impact } \\
\text { and } 2 \text { being a very positive impact }\end{array}$ & positive \\
\hline ACCESS & $\begin{array}{l}\text { Respondent's belief that forest biomass production will } \\
\text { have a positive impact on access to land not owned by the } \\
\text { respondent using a five-point Likert scale, with }-2 \text { being a } \\
\text { very negative impact and } 2 \text { being a very positive impact }\end{array}$ & positive \\
\hline YOUTH & $\begin{array}{l}\text { Respondent's belief that forest biomass production will } \\
\text { have a positive impact on younger individuals' ability to } \\
\text { stay in the community using a five-point Likert scale, } \\
\text { with - } 2 \text { being a very negative impact and } 2 \text { being a very } \\
\text { positive impact }\end{array}$ & positive \\
\hline CARBON & $\begin{array}{l}\text { Respondent's belief that forest biomass production will } \\
\text { have a positive impact on carbon dioxide storage using a } \\
\text { five-point Likert scale, with }-2 \text { being a very negative } \\
\text { impact and } 2 \text { being a very positive impact }\end{array}$ & positive \\
\hline LANDSCAPE & $\begin{array}{l}\text { Respondent's belief that forest biomass production will } \\
\text { have a positive impact on the aesthetics of local } \\
\text { landscapes using a five-point Likert scale, with }-2 \text { being a } \\
\text { very negative impact and } 2 \text { being a very positive impact }\end{array}$ & positive \\
\hline CCBELIEF & $\begin{array}{l}\text { Respondent agrees that burning fossil fuels is a primary } \\
\text { driver of climate change, } 1 \text { if yes, } 0 \text { otherwise }\end{array}$ & positive \\
\hline SUPPLIER & $\begin{array}{l}\text { Owns } 20 \text { or more acres of forest land, } 1 \text { if yes, } 0 \\
\text { otherwise }\end{array}$ & positive \\
\hline GOVCAP & $\begin{array}{l}\text { Respondent's belief that the government (DNR) is } \\
\text { capable of mitigating negative environmental effects of } \\
\text { woody biomass production promote the use of forest } \\
\text { biomass for electricity production, } 1 \text { if yes, } 0 \text { otherwise }\end{array}$ & positive \\
\hline AGE & $\begin{array}{l}\text { The age of the respondent, } 1 \text { if older than } 60 \text { years, } 0 \\
\text { otherwise }\end{array}$ & positive \\
\hline INCOME & $\begin{array}{l}\text { The annual household income of respondent, } 1 \text { if } \$ 75,000 \\
\text { or greater, } 0 \text { otherwise }\end{array}$ & positive \\
\hline GENDER & The gender of the respondent, 1 if male, 0 otherwise & positive \\
\hline
\end{tabular}


EDUCATION $\quad$ The highest level of respondent education, 1 if college degree or higher, 0 otherwise

positive

Biomass production has a broad range of potential effects that may influence the general public's support or opposition, and individuals' perception of these effects can vary greatly. The perception of these effects can loosely be categorized as environmental, economic and social. Respondents were given a series of 20 potential biomass effects (e.g. jobs, water quality, landscape aesthetics) and asked if they believed woody biomass production would have "very negative impacts" (coded as "-2") to "very positive impacts" (coded as "+2") using a five-point Likert scale. Many of these question items were highly correlated with each other, so a reduced set of biomass effect questions were selected to mitigate potential effects of multi-collinearity. Five biomass effects were selected for inclusion in the study's regression model. Effects to the local economy (ECON), access to lands not owned by the respondent (ACCESS), landscape aesthetics (LANDSCAPE), carbon dioxide sequestration (CARBON) and younger community members' ability to stay in the community (YOUTH) were selected. These five variables represent a cross section of social, environmental, and economic effects and did not indicate potential multicollinearity effects in prescreening variables. It was hypothesized that positive levels of ACCESS, ECON, LANDSCAPE, YOUTH, and CARBON would be positively correlated with SUPPORT among respondents. This hypothesis is made assuming that respondents' support of natural resource management systems is often based on utility maximization. Projects and processes that maximize personal utility 
are assumed to be more favorable to respondents. Increased access to forestlands, stronger economies, more aesthetically pleasing landscapes, reduced net greenhouse gas emissions, and more opportunities (e.g. jobs) for younger residents are assumed to contribute positively to the general public's overall well-being and positively contribute to respondent's utility. Therefore, individuals who believe that biomass production will lead to positive socio-environmental effects like these will be more likely to support forest biomass production.

Bioenergy familiarity (FAMILIARITY) was measured by asking if the respondents were aware that forest resources were considered a source of renewable energy (Halder et al., 2014), if they knew that woody biomass could be used to produce electricity and if they knew that woody biomass was being used locally to produce electricity (in Rothschild). Respondents were given the response options of either "yes" (coded as "2"), "no" (coded as "0") or "unsure" (coded as "1") for each question except for the question regarding the respondent's knowledge of the Rothschild plant's use of woody biomass. For this former question, respondents were only given a response option of "yes" (2) or "no" (0). The values for these three questions were added together to create a scale with a maximum value of " 6 " indicating a high level of FAMILIARITY and " 0 " representing a respondent with low levels of FAMILIARITY. Higher levels of FAMILIARITY are hypothesized to have a positive correlation with SUPPORT. This is hypothesized under the assumption that respondents with higher levels of FAMILIARITY are more aware of the potential climate change mitigation and job creation benefits. 
Climate change is one of the primary justifications given for bioenergy production. Respondents were asked if they agreed with the following statement: "Burning fossil fuels is one of the primary causes of climate change." Individuals who agreed with this statement (CCBELIEF) are hypothesized to be more likely to support woody biomass production, given that its sustainable production is intended to mitigate the effects of greenhouse gas emissions from using fossil fuels. Individuals who agreed to the statement were coded as " 1 ". Those who disagreed or were neutral were coded as " 0 ".

Forest ownership (SUPPLIER) was included in the model given that they are the current and potential supplier of biomass. Respondents were asked to indicate ("yes" or "no") if someone in their household owned forestland, and if "yes", how many acres. Individuals who indicated owning more than 20 acres of forestland were coded as "1" given that owners with larger forestlands are more likely to participate in biomass production. Those with less than 20 acres were coded as " 0 ". It was hypothesized that SUPPLIER is positively correlated with SUPPORT since there is a potential economic opportunity to supply biomass to the power plant. Larger landowners are also more likely to have participated in other forms of forest management and consider biomass production as an extension of current practices.

Respondents were asked if he/she agreed with the following question: "The government (e.g. Wisconsin DNR) will do an adequate job of enforcing laws to protect the environment if harvesting of forest resources for electricity production increases." (GOVCAP). Respondents who agree were coded as "1", and respondents 
who disagreed or were neutral were coded as " 0 ". Individuals who agree to the statement are hypothesized to be positively correlated with SUPPORT given that the respondent believes some of the potential negative effects of biomass production would be mitigated through government intervention. This risk reduction would eliminate a potential barrier to woody biomass production support.

As previously indicated, several studies have found evidence that sociodemographic characteristics of respondents influence SUPPORT. Household income (INCOME) is hypothesized to be positively associated with SUPPORT as these individuals have greater ability to pay for potential increases in energy prices. Respondents with annual household incomes of $\$ 75,000$ or more were coded as "1" and the remaining respondents were coded as "0". Studies have shown that gender (GENDER) is often correlated with differences in attitudes toward bioenergy systems (Halder et al., 2012; Solomon \& Johnson, 2009). Respondents who identified themselves as "male" were coded as " 1 " and "female" as " 0 ". Educational attainment (EDUCATION) was coded as "1" for individuals who have obtained a college degree or higher level of education, and "0" otherwise. EDUCATION was hypothesized to have a positive correlation with SUPPORT because greater education would make respondent more likely to understand the environmental and socioeconomic issues of climate change, which bioenergy use is expected to mitigate. Respondents who indicated their age (AGE) to be 60 years old or above were coded as " 1 " and everyone else was coded as " 0 ". AGE is hypothesized to be positively associated with SUPPORT as well, because these individuals belong to the 
cohort that lived during the major environmental movements of the 1970s, which often focused on the positive effects of alternative energy and biofuels.

\subsection{Results}

\subsubsection{Sample Description}

A total of 292 completed surveys were collected from the Tomahawk community

(Table 13). A total of 250 were collected in person while in the field $(7 / 20-8 / 1)$ and an additional 44 were returned by mail. Of the original 508 households pulled into the sample, a total of 124 were removed from the sample because the selected address was deemed vacant, no trespassing or couldn't be found. A total of 95 replacement addresses was added to make up for the removals ${ }^{4}$. This resulted in 479 eligible households to complete the survey $(508-124+95=479)$. From this total, 84 households refused to participate while 101 households failed to return a survey. Two surveys are considered "duplicates" as two separate homes each completed two surveys. One randomly selected survey from each of these households was removed from the final survey response (and not included in the 292 completed surveys). This resulted in a response rate of $61.0 \%(292 / 479)$. This falls between the desired confidence interval of 5\% (369 responses) and 10\% (95 responses) when using a $95 \%$ confidence level.

\footnotetext{
${ }^{4}$ Only 95 households were added back in since many of the homes were not declared "vacant" until the last day in the field and no time was left to add new households.
} 
Table 13: Survey response rate

\begin{tabular}{|c|c|c|c|c|c|c|}
\hline $\begin{array}{c}\text { Original } \\
\text { Sample }\end{array}$ & $\begin{array}{c}\text { Added } \\
\text { Addresses }\end{array}$ & Refusals & $\begin{array}{c}\text { Non- } \\
\text { Respondents }\end{array}$ & $\begin{array}{c}\text { Vacant } \\
\text { Homes }\end{array}$ & $\begin{array}{c}\text { Addresses Not } \\
\text { Found/ } \\
\text { No Trespassing }\end{array}$ & $\begin{array}{c}\text { Completed } \\
\text { Surveys }\end{array}$ \\
\hline 508 & 95 & 84 & 101 & 114 & 10 & 292 \\
\hline
\end{tabular}

Table 14 summarizes the sample's demographics and compares it the 20102014 American Community Survey 5-year estimate for Tomahawk. Approximately half of the respondents (50.3\%) identified themselves as male, while $42.8 \%$ identified themselves as female. The balance did not indicate a gender. The majority of respondents were between 40 and 79 years old (76.1\%). The sample indicates that $62.4 \%$ of respondents have some college or university education with $31.2 \%$ having at least a bachelor's degree. Overall, the response appears to be biased towards males, respondents who have some college education or graduated from college, higher household incomes, and individuals between the ages of 60 and 79 years old. Income bias may be less, however, since $20.2 \%$ of the sample declined to provide a response to the household question, and many of these may belong to the lower income groups. 
Table 14: Socio-demographic characteristics of Tomahawk survey respondents $(\mathrm{N}=292)$

\begin{tabular}{|lcc|c|}
\hline \multicolumn{1}{l}{ N } & Sample \% & Population \% \\
Gender & & & \\
Female & 147 & 50.3 & 48.7 \\
Prefer not to answer & 125 & 42.8 & 51.3 \\
Age & 20 & 6.8 & \\
$18-39$ & & & \\
$40-59$ & 44 & 15.1 & 28.5 \\
60-79 & 110 & 37.7 & 34.7 \\
$80+$ & 112 & 38.4 & 24.9 \\
Prefer not to answer & 18 & 6.2 & 11.9 \\
Education level & 8 & 2.7 & \\
Less than high school degree & 11 & 3.8 & 5.4 \\
High school degree & 75 & 25.7 & 36.0 \\
Some college or university & 91 & 31.2 & 21.6 \\
Graduated from college & 91 & 31.2 & 26.4 \\
Prefer not to answer & 24 & 8.2 & \\
Annual Household Income & & & \\
Less than \$25,000 & 39 & 13.4 & 33.9 \\
\$25,000-\$49,999 & 67 & 22.9 & 26.9 \\
\$50,000-\$74,999 & 58 & 19.9 & 6.2 \\
\$75,000-\$99,999 & 39 & 13.4 & \\
Above \$100,000 & 30 & 10.3 & \\
Prefer not to answer & 59 & 20.2 & \\
Owns 20+ acres of forestland & & & \\
Yes & 66 & 22.6 & \\
No or missing & 226 & 77.4 & \\
\hline
\end{tabular}

\subsubsection{Ecosystem Services Values}

Respondents were asked to assess the importance of forest ecosystem services using two measures. The first provided a list of 11 ecosystem services whereby respondents were asked to use a five-point Likert scale $(1=$ not very important, $5=$ very important). Figure 3 shows the results. Nine ecosystem services received an 
average score of 4 or higher, with water quality regulation and air quality regulation (referred to as clean water and clean air, respectively) tied for the service with the highest average importance score (4.84). These services had relatively low standard deviations of 0.42 (air quality regulation) and 0.43 (water quality regulation), indicating consensus among respondents that the services had high perceived importance. Jobs (mean 4.02, SD 1.17), wild food (mean 3.96, SD 1.18), and firewood (mean 3.60, SD 1.27), all of which are generally regarded as provisioning services, were the lowest rated services. However, these three services also had the highest standard deviations of the set, indicating substantial variation between respondents' answers.

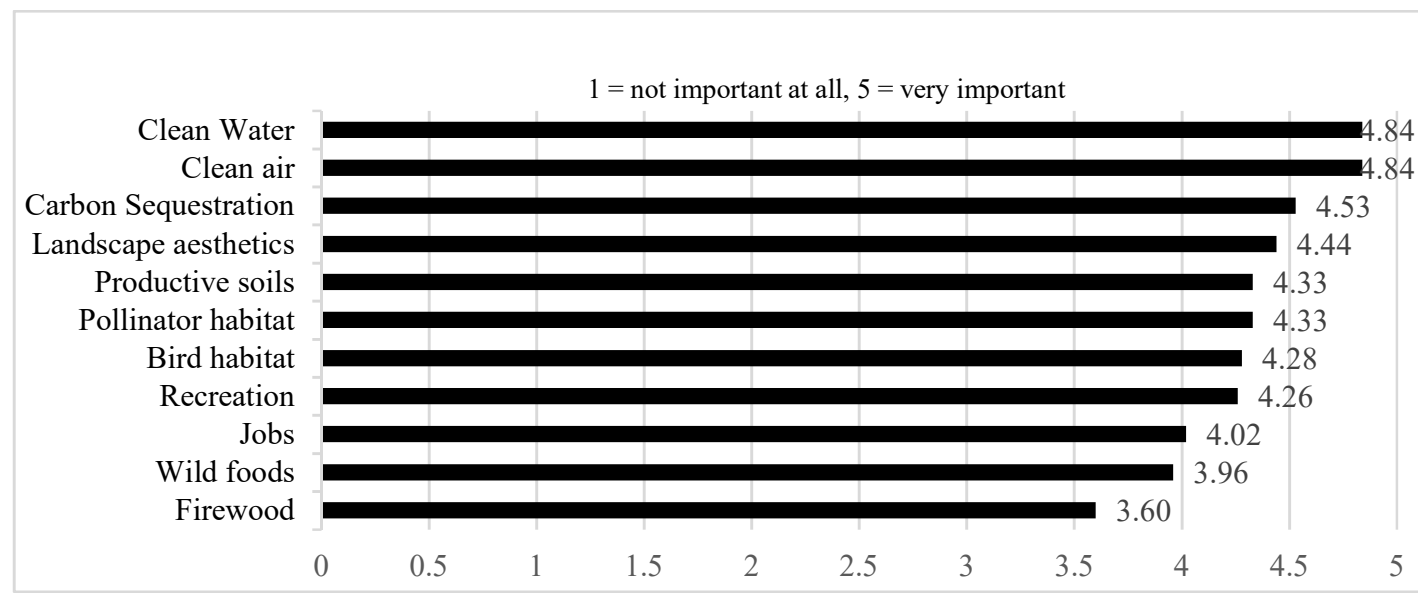

Figure 3: Importance of forest ecosystem services using five-point Likert scale $(\mathrm{N}=288)$

The second forest ecosystem service valuation measure asked respondents to allocate between ten services a fixed sum of money (or credits) under the prompt that the more money/credits allocated to a particular service helped preserve it. In effect, 
the question was meant to place respondents in a position to prioritize services under a resource constrained situation similar to what policymakers often face in natural resource management. It was assumed that doing so would reveal respondents' true preferences in ways that the aforementioned Likert-scale method does not (where all, or almost all services are ranked as important/very important). The results of this measure are displayed in Figure 4. In this assessment, water quality regulation received the highest average allocation of credits (mean 18.46, SD 15.20), followed by wildlife habitat (mean 13.42, SD 12.72) and hunting (mean 10.95, SD 15.22). The least prioritized services were motorized recreation (mean 5.14, SD 11.92), soil erosion prevention (mean 7.07, SD 8.95) and non-motorized recreation (mean 7.61, SD 11.96). The high standard deviations indicate large variation in the data set.

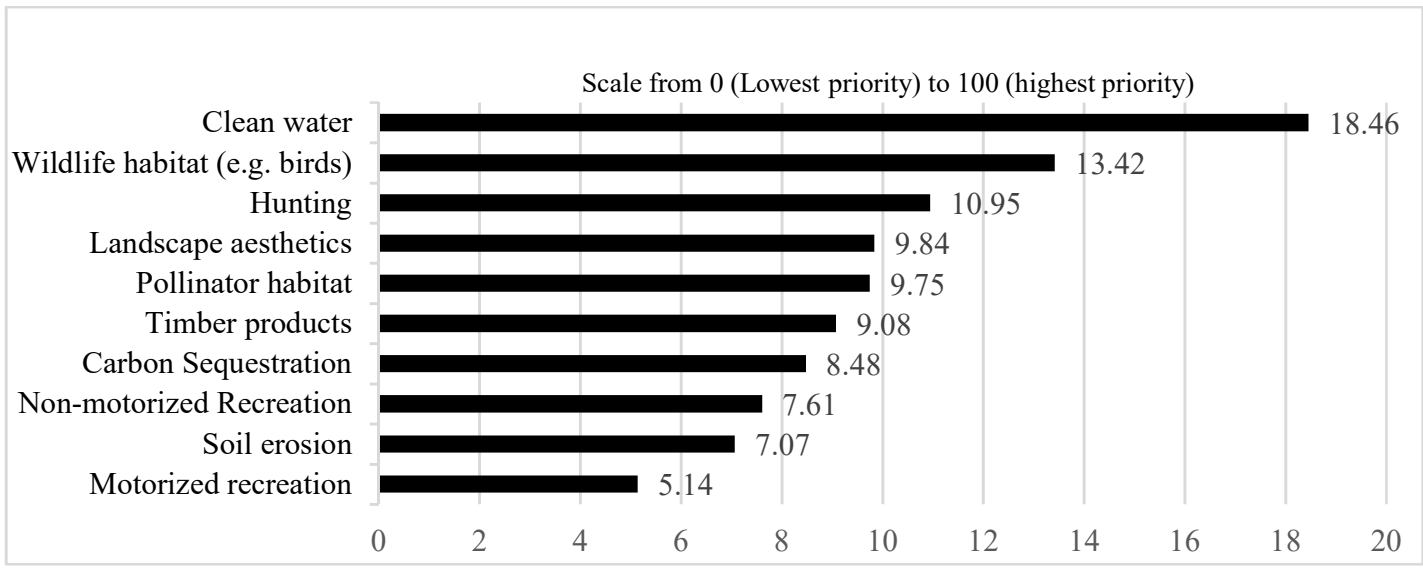

Figure 4: Importance of forest ecosystem services using $\$ 100$ spending exercise $(\mathrm{N}=283)$

\subsubsection{Perception of Forest Biomass Production Effects}

Respondents were asked to indicate their perception of effects of local biomass production on a range of socio-ecological topics using a five-point Likert scale, 
where a response of "-2" indicated a prediction of very negative impacts and a response of " +2 " indicated that the respondent believed biomass production would have a very positive impact. Figure 5 displays the results of this section.

Respondents indicated that the most positive effect of forest biomass production was an increase in "well-paying jobs" with a score of +0.87 . Predominately, respondents believed that biomass production would have relatively positive economic effects (e.g. jobs and the overall local economy); while ecological effects (e.g. carbon storage, wildlife habitat, air and water quality) were generally perceived as neutral or slightly negative. Community effects (e.g. youth staying in the community, local land ownership, access to land not owned by the respondent) generally had slightly positive effect perceptions. Landscape beauty was expected to be the most negatively affected out of all those listed with a score of -0.43 .

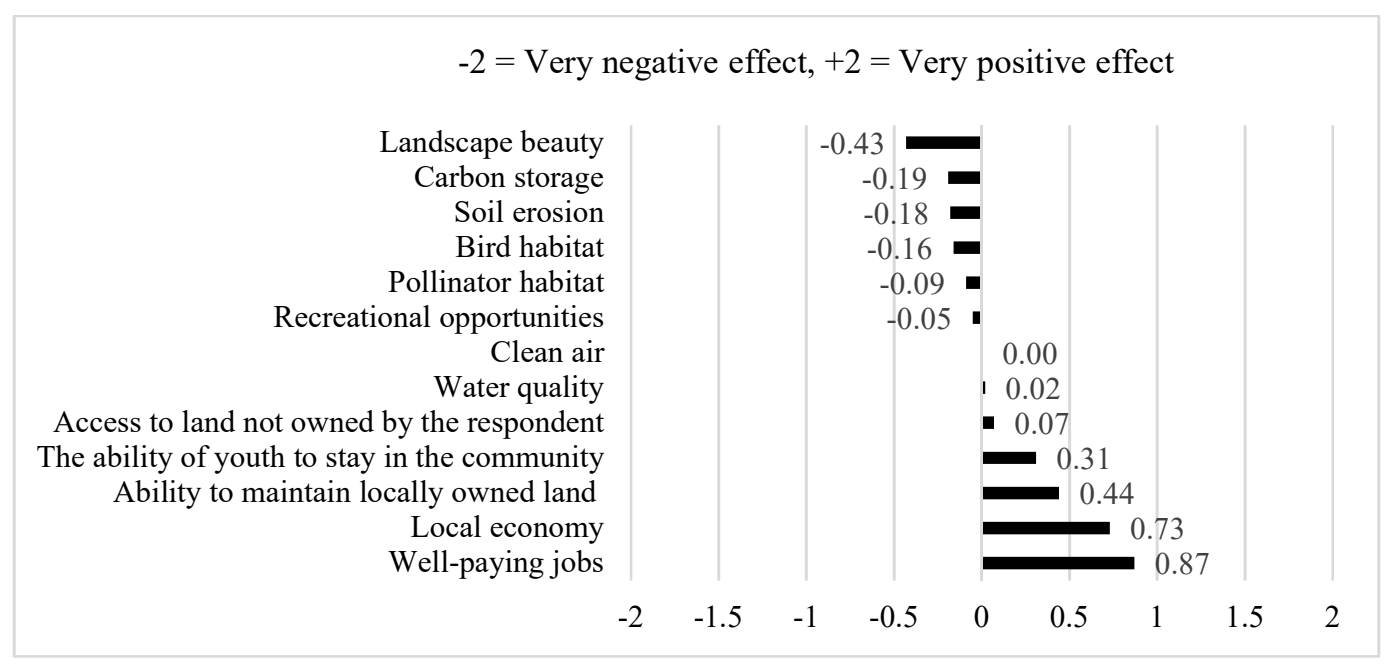

Figure 5: Perceptions of local forest biomass production effects 


\subsubsection{Support for Biomass Sources}

Respondents were asked to indicate their overall level of support for the use of biomass from forest for electricity production (dependent variable) along with specific sources of forest biomass. Respondents used a five-point Likert scale, where "1" indicated strong opposition, "3" indicated a neutral opinion, and " 5 " indicated strong support. Figure 6 shows the results for this question set. For overall support of the use of forest biomass, respondents averaged 3.31 (SD 1.12), slightly above neutral. Just more than half of respondents (50.7\%) agreed or strongly agreed that they support the use of forest biomass materials for electricity production, $26.3 \%$ indicated a neutral response, and $23.0 \%$ indicated they disagreed or strongly disagreed. Of the specific sources of forest-based biomass, three sources achieved an average response above the support level (4 or higher). Saw and paper mill waste was rated the highest with a mean of 4.21 (SD 0.97), followed closely by forest health improvement thinnings (mean 4.17, SD .783) and forest residues (mean 4.10, SD 1.01). Forest clearing for agricultural development received the lowest score (mean 2.84, SD 1.24), followed by dedicated harvest of low value trees (mean 3.71, SD 1.00). Forest clearings, which appears to be the most controversial forest biomass source, received responses indicating strong opposition (15.8\%) and opposition (27.0\%). Only $10.9 \%$ and $21.1 \%$ of respondents respectively indicated "strong support" or "support" for biomass generated through forest clearings to agricultural lands. 
$1=$ Strongly oppose, $5=$ Strongly support

Overall support for producing biomass from forests

Saw and paper mill waste

Forest thinnning to improve forest health

Forest residues after logging

Dedicated harvest of low value trees

Forest cleared for agricultural development

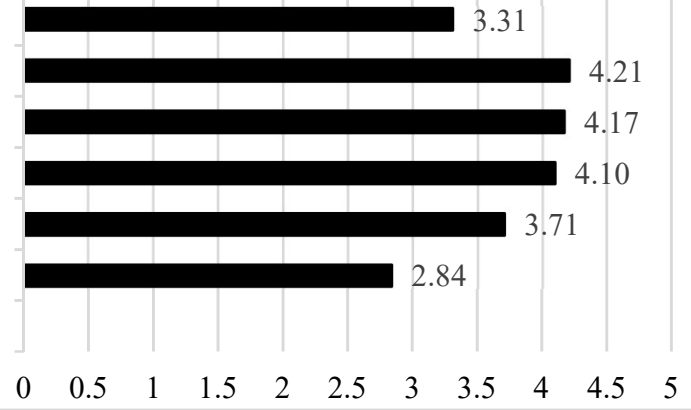

Figure 6: Support for different sources of forest biomass production $(\mathrm{N}=278)$

\subsubsection{Principal Component Analysis}

Principal component analysis (PCA) was used for data reduction and to identify noncorrelating latent factors pertaining to respondents' forest-based ecosystem service values. The dimensions were identified using the Direct Oblimin rotation command in SPSS under the expectation that some of the variables may be correlated with each other. Factor scores were exported using the Anderson-Rubin method to reduce correlation between dimensions when used in regression analysis. The higher the loading score, the more variation within the variable can be explained by the principal component. Variables with loading scores less than 0.50 were removed from dimensions.

PCA focused on the set of 11 forest-based ecosystem service valuation questions that used a five-point Likert scale to indicate importance ratings. ${ }^{5}$ Three

\footnotetext{
${ }^{5}$ Note that a similar PCA analysis was conducted using the ecosystem service valuation questions that derived importance values through the fixed money/credit allocation process. However, the PCA produced a KMO score of 0.02 indicated that the data sets variation was not well explained through fewer latent variables.
} 
latent concepts were identified that explained $58.0 \%$ of the variance within these variables. Table 15 displays the results of this PCA. Three latent dimensions were identified, and it appears that the dimensions closely follow the MEA classification scheme. PC1 contains variables that can generally be described as regulating or supporting ecosystem services and explains $33.6 \%$ of the variance within these 11 variables. The dimension includes services such as bird and pollinator habitat, soil quality regulation (referred to as "productive soils" in the survey), water and air quality regulation, and carbon sequestration. The one anomaly in the dimension is the inclusion of "wild foods", which is generally classified as a provisioning service. PC2 explains $14.1 \%$ of the variation and includes two services (jobs and firewood) and represent provisioning ecosystem services. PC3 explains $10.3 \%$ of the variation and include two variables (recreation and landscape aesthetics) that are generally categorized as cultural ecosystem services. 
Table 15: Unobservable dimensions of respondents' social value of forest-based ecosystem services $(\mathrm{N}=292)$

\begin{tabular}{|c|c|c|c|}
\hline Key dimensions and items & $\begin{array}{l}\text { Mean Social Values } \\
\text { (1 Not at all important } \\
\text { to } 5 \text { Very important) }\end{array}$ & $\begin{array}{l}\text { Loadings on } \\
\text { dimensions }\end{array}$ & $\begin{array}{c}\text { Variance } \\
\text { explained } \\
(\%)\end{array}$ \\
\hline Regulating \& Supporting (PC1) & & & 33.6 \\
\hline Bird habitat & 4.28 & .77 & \\
\hline $\begin{array}{l}\text { Habitat for pollinators of food crops } \\
\text { (e.g. bees) }\end{array}$ & 4.33 & .74 & \\
\hline Productive soils & 4.33 & .72 & \\
\hline $\begin{array}{l}\text { Stores carbon or takes carbon out of the } \\
\text { atmosphere }\end{array}$ & 4.53 & .64 & \\
\hline Wild foods (e.g. wild game, mushrooms) & 3.96 & .57 & \\
\hline Clean air & 4.84 & .55 & \\
\hline Clean water & 4.84 & .50 & \\
\hline Provisioning (PC2) & & & 14.1 \\
\hline Jobs & 4.02 & .60 & \\
\hline Firewood & 3.60 & .55 & \\
\hline Cultural (PC3) & & & 10.3 \\
\hline A visually pleasing landscape & 4.44 & 67 & \\
\hline Recreation (e.g. camping, hiking) & 4.26 & .63 & \\
\hline
\end{tabular}

\subsubsection{Binomial Logistic Regression Model}

Table 16 displays the results of the binomial logistic regression model on support for forest biomass production for electricity. Multicollinearity diagnostics were conducting by evaluating VIF scores and bivariate correlations between independent variables. No strong correlation value (VIF score above 3.0 or bivariate correlation above 0.70 ) between independent variables was identified, so multicollinearity concerns are very low. The model significantly improved the prediction of the dependent variable at the $99 \%$ confidence level. Table 16 shows that the model's predictive capacity is $77.3 \%$, a $25.5 \%$ improvement when not including the model's 
independent variables. The model explains between 36.5\% (Cox \& Snell $\left.\mathrm{R}^{2}\right)$ and $48.7 \%$ (Nagelkertke $\mathrm{R}^{2}$ ) of the variance within the dependent variable.

The model indicates that seven variables have statistically significant correlation with SUPPORT. All three ESVALUE dimensions produced through principal component analysis had statistically significant correlations with SUPPORT. Individuals who placed higher importance values on supporting and regulating forest-based ecosystem services (SUP\&REG) were negatively correlated with SUPPORT at the 99\% confidence level. The expected beta in Table 17 offers the independent variable's contribution to the increase (or decrease) in odds in indicating support for forest biomass production. In the case of SUP\&REG, a oneunit increase in this variable's factor score leads to a $44.2 \%$ reduction in supporting local forest biomass production. Inversely, respondents who placed higher values on provisioning services of forests (PROVISION) and cultural services (CULTURE) were positively correlated with supporting forest biomass production. Both were statistically significant at the $90 \%$ confidence level. An increase in the respondent's PROVISION led to a $38.1 \%$ chance in indicating a positive SUPPORT value, while an increase in CULTURE led to a $37.7 \%$ odds of having a positive SUPPORT value.

Three biomass effects were found to have positive statistically significant correlations with SUPPORT, and supported the study's hypothesis that perceived positive effects of biomass production generally lead to a higher likelihood in supporting forest biomass production. The strongest predictor included in the study's model was ECON, which was statistically significant at the $99 \%$ confidence 
level. A one-unit increase in ECON leads to $167.5 \%$ increase in likelihood of supporting forest biomass production. YOUTH had a positive correlation with SUPPORT at the $95 \%$ confidence level, and a one-unit increase in YOUTH leads to a $67.2 \%$ increase in a respondent's likelihood to support forest biomass production. CARBON was positively correlated with SUPPORT at the $90 \%$ confidence level. A one-unit increase in CARBON led to a $39.5 \%$ increase in the likelihood a respondent would have a positive SUPPORT value. The results also provide support for the study's hypothesis regarding the relationship between a respondent's familiarity with forest biomass-related bioenergy and SUPPORT. The study's results show that FAMILIARITY was positively correlated with SUPPORT at the $95 \%$ confidence level. For each increase in the 6-point scale, the odds of respondents indicating support of forest biomass production increased by $22.4 \%$. 
Table 16: Results of logistic regression on forest biomass production support - full model

\begin{tabular}{|c|c|c|c|}
\hline Variable & $\beta$ Coefficient & Std. Error & $\operatorname{Exp}(\beta)$ \\
\hline \multicolumn{4}{|l|}{ Biomass Production Effects } \\
\hline ECON & $.984^{\mathrm{a}}$ & .230 & 2.675 \\
\hline ACCESS & .290 & .232 & 1.337 \\
\hline LANDSCAPE & ..209 & .179 & 1.233 \\
\hline YOUTH & $.514^{\mathrm{b}}$ & .223 & 1.672 \\
\hline CARBON & $.333^{\mathrm{c}}$ & .185 & 1.395 \\
\hline \multicolumn{4}{|l|}{ ES Values } \\
\hline SUP\&REG & $-.583^{\mathrm{a}}$ & .202 & .558 \\
\hline PROVISION & $.323^{\mathrm{c}}$ & .177 & 1.381 \\
\hline CULTURE & $.320^{\mathrm{c}}$ & .169 & 1.377 \\
\hline CCBELIEF & -.374 & .374 & .688 \\
\hline GOVCAP & -.031 & .345 & .969 \\
\hline FAMILIARITY & $.202^{\mathrm{b}}$ & .103 & 1.224 \\
\hline SUPPLIER & -.251 & .359 & .778 \\
\hline AGE & -.365 & .361 & .694 \\
\hline INCOME & -.500 & .414 & .607 \\
\hline EDUCATION & .069 & .375 & 1.071 \\
\hline GENDER & .029 & .361 & 1.029 \\
\hline CONSTANT & -.728 & & \\
\hline Omnibus Test of Model Coefficients & .000 & & \\
\hline Wald Chi-square & 115.87 & & \\
\hline Cox \& Snell $\mathrm{R}^{2}$ & $36.5 \%$ & & \\
\hline Nagelkertke $\mathrm{R}^{2}$ & $48.7 \%$ & & \\
\hline Hosmer and Lemeshow Test & .376 & & \\
\hline No. of observations & 255 & & \\
\hline a Significance at $1 \%$ level & & & \\
\hline b Significance at $5 \%$ level & & & \\
\hline c Significance at $10 \%$ level & & & \\
\hline
\end{tabular}

Table 17: Actual and predicted values for forest biomass production support - full model

\begin{tabular}{|c|c|c|c|c|}
\hline Actual & \multicolumn{2}{|c|}{ Predicted } & Total & $\%$ Correct \\
\hline & 0 & 1 & & \\
\hline 0 & 94 & 29 & 123 & 76.4 \\
\hline 1 & 29 & 103 & 132 & 78.0 \\
\hline Total & & & 255 & 77.3 \\
\hline
\end{tabular}

Of the 16 independent variables in the model, nine were found to be insignificant and therefore cannot support the study's hypotheses pertaining to these variables. The coefficients for ACCESS, LANDSCAPE, EDUCATION, and GENDER, while not statistically significant, were positive as predicted. In contrast, 
the coefficients for GOVCAP, SUPPLIER, AGE, CCBELIEF and INCOME were negative.

\subsection{Discussion}

\subsubsection{Ecosystem Services Values and Support for Local Biomass Production}

The general public's social acceptance of forest-based biomass production is complex and multifaceted. This study attempted to shed light on this topic by exploring the connection between socially prioritized ecosystem services and social acceptance of a natural resources management system. Attitudes, like the importance an individual places on ecosystem services, can influence an individual's overall perception of effects of biomass production by filtering information synthesis, and this can ultimately influence behavior (Fazio, 1989). Respondents' perceptions of the benefits of ecosystem services can help explain why they may support or oppose production systems that threaten the supply of these benefits (Asah et al., 2014). The study's statistical analysis supports the idea that an individual's social value of different ecosystem services groups can be linked with support or opposition to local forest-biomass production. This finding aligns with previous work that identified a correlation between ecosystem service values and forest use preferences (Clement \& Cheng, 2011). Intuitively, this makes sense. Forest biomass production has the capacity to affect many forest-based ecosystem services, and it is logical that 
respondents who believe highly valued services are threatened would be less likely to support such a system, with the inverse also likely being true. Utility theory posits that decisions are driven primarily by rational actors' pursuit of personal preferences maximization (Fishburn, 1970). The aforementioned rationale fits nicely within the utility theory framework. Following it to its reasonable conclusion, the higher level of importance placed on an ecosystem service, the more influence its potential impact will have on an individual's support for a natural resource management system.

The direction of influence of ecosystem service values on forest-biomass production support aligns closely with studies of environmental attitudes and the ecocentrism - anthropocentrism spectrum (Dunlap et al., 2000; Kempton et al., 1996; Thompson \& Barton, 1994). In this study, individuals with higher levels of importance placed on supporting and regulating services were less likely to support forest biomass production, while individuals who placed higher levels of importance on cultural and provisioning services were more likely to support biomass production. Here, individuals who place higher values on supporting and regulating services are presumed to fall closer to the ecocentrism end of the spectrum given that these services provide functions critical to all life on Earth (e.g. habitat for wildlife, clean air, clean water, etc.). And individuals who placed higher importance on provisioning and cultural services would likely fall closer to the anthropocentrism end of the spectrum, since these services provide benefits specifically useful to humans (e.g. building materials, jobs, recreation). It should come as no great 
surprise that individuals who place a high value on provisioning services would support biomass production since producing heat and electric power from forest materials is a provisioning ecosystem service.

\subsubsection{Social Values of Forest Ecosystem Services}

This study also contributes to the growing literature on the valuation of ecosystem services. Similar to previous work on rural populations, residents of Tomahawk, WI placed a high level of importance on a wide variety of ecosystem services (MartínLópez et al., 2012; Soy-Massoni et al., 2016), unlike in urban regions where forests are often valued more for recreation, psychological and aesthetic benefits (Hauru et al., 2015). When given an unrestricted means to measure the importance of each service, respondents placed a high level of importance on all services. However, when forced to prioritize, respondents indicated that supporting, regulating and cultural services were most important. This also aligns with findings that show remote communities prioritize cultural services over provisioning services (Darvill \& Lindo, 2014). We can identify "critical" ecosystem services by identifying services of high social value and that are perceived to be threatened by a biomass production system (Iniesta-Arandia et al., 2014). Using a Likert scale measurement, this study indicates respondents perceive landscape aesthetics, carbon storage, wildlife habitat, and recreational opportunities as both important and under threat if forest biomass harvesting were to occur. However, important but non-vulnerable services include water and air quality regulation and jobs. 
These findings have significant implications for policy makers and proponents of bioenergy projects that rely on forest biomass. First, for biomass production systems to achieve social acceptance, projects must be sensitive to "critical" ecosystem services. Understanding how individuals derive benefits from forests help to predict how individuals will respond when those benefits are perceived to be threatened (Asah et al., 2014). Procurement strategies should balance the need for economic efficiencies with multi-use needs of communities. This includes cultural ecosystem services like landscape and recreation impacts, which often get limited attention during sustainability assessments that prioritize environmental and economic effects (Chan et al., 2012). Second, biomass production effects are inherently local. In Wisconsin, sustainable forest management is guided by a mixture of state, local and market-based mechanisms. Applying the ecosystem service framework at the state and local level can be challenging. Clear definitions, guidelines and accounting mechanisms need to be established in order for biomass production projects to effectively be applied (Beery et al., 2016).

\subsubsection{Support for Forest Biomass Production: Sources Matter}

In the case of Tomahawk, WI, the general public's support for producing biomass from unspecified forest materials was tepid at best. However, once specific sources of forest biomass were presented, the general public's acceptance of forest biomass became clearer. Similar to previous studies, biomass sources from perceived "waste streams" like logging residues and mill processes, were supported (Plate et al., 
2010). In contrast, biomass procurement sources perceived to negatively impact the availability of forestland (e.g., land-use change) were more likely to be opposed. Projects that are seen to improve forest health are seen as "win-win" and achieve higher support (Plate et al., 2010; Singer, 2013; Stidham \& Simon-Brown, 2011). This indicates that the general public's social acceptance of forest biomass production requires clear indication of how that biomass is produced. In other words, the ends (in this case, electricity produced from local resources) do not necessarily justify the means. Policy makers and biomass project developers face an uphill battle in achieving public support for biomass production if it leads to land-use change or dedicated harvesting of low value trees is required to produce raw materials for energy. Biomass source uncertainty may lead the public to initially oppose a project because of concerns over harvest intensity and other ecological risks (Pires, 2011). The results of the study also corroborated previous work that indicated bioenergy familiarity (Wegener \& Kelly, 2008), perceived benefits to society (Marciano et al., 2014; Radics et al., 2016), specifically job creation (Stidham \& Simon-Brown, 2011), greenhouse gas sequestration (Marciano et al., 2014), and enhancing young community members' ability to stay in the community are positively related with support bioenergy systems. These findings align with many of the arguments for bioenergy production, such as climate change mitigation and economic development. The ability for biomass production to create local jobs, particularly for younger community members who are leaving many rural 
communities throughout rural North America for social and economic opportunities, helps to bolster biomass production support.

Some specific bioenergy effects found in previous studies were not supported by this work. Air and water quality effects were not found to be statistically significant with this study (Marciano et al., 2014). This may be because previous work focused on acceptance of the conversion facility, and not the biomass production supply chain. Belief in anthropogenic induced climate change due to fossil fuel combustion was also not found to be a driver of support for biomass production. The study did not support previous work that indicated demographic characteristics such as income (Marciano et al., 2014; Mozumder et al., 2011; Roe et al., 2001; Soliño et al., 2009; Solomon \& Johnson, 2009; Susaeta et al., 2011; Zografakis et al., 2010), gender (Gossling et al., 2005), and educational attainment (Solomon \& Johnson, 2009) influenced support for bioenergy systems. This could be because of the study's smaller sample size or coarse measures, but it could also be driven by controlling for perceptions of biomass production effects and ecosystem service values, which negate the influence of demographic variables. This study's results indicate that the use of demographic characteristics may mask the true underlying factors that determine bioenergy system support.

Finally, the study's results suggest that the general public, particularly in an area with a long history of forest product manufacturing, generally agrees that biomass production leads to positive economic benefits. However, respondents had less clear opinions on the environmental effects of biomass production. Overall, 
respondents' perceptions of ecological effects were believed to most likely be neutral or slightly negative. This could indicate a lack of certainty or understanding of the ecological implication of using forest biomass for power production. However, equally as likely, this may show that respondents are attuned to the fact that forest materials can be derived using several in-forest management techniques and sources (e.g. forest residues versus mill residues). This lack of certainty may be attributed to the fact that the survey did not specifically stipulate the source of forest biomass, therefore respondents were unwilling to make strong agreements with the types of impacts that biomass production would make. This may have led many respondents to choose "neutral" for ecological effects of biomass production since they were not specifically told which forest materials harvesting method or source to focus on. Future studies should clearly distinguish biomass sources and harvesting techniques so that respondents have the information necessary to evaluation potential socioeconomic and ecological effects.

\subsection{Conclusion}

The study's results provide evidence that the general public's support for forest biomass production systems differed based on the level of importance placed on forest-based ecosystem service by respondents, the perception of biomass production's effects on job creation, greenhouse gas sequestration, enhancement of young community members' ability to stay in the community, and previous levels of bioenergy familiarity. The study also highlighted that rural respondents highly value 
a wide variety of ecosystem services. However, when pressed to prioritize, cultural, supporting and regulating ecosystem services take precedent over provisioning services. Several ecosystem services were identified as critical by respondents, where the services were both perceived as important in addition to negatively impacted if biomass production from forestlands were to increase. The challenge for policy makers and project developers is navigating the diverse terrain of ecosystem service values and biomass production support. While respondents indicate that many ecosystem services are important, economic effects appear to have the greatest bearing on support for biomass production. Nonetheless, this study has provided evidence that natural resource management decisions require a multi-faceted, multivalued approach in order to achieve a socially accepted, and ultimately, sustainable bioenergy system. 


\subsection{References}

Asah, S. T., Guerry, A. D., Blahna, D. J., \& Lawler, J. J. (2014). Perception, acquisition and use of ecosystem services: Human behavior, and ecosystem management and policy implications. Ecosystem Services, 10, 180-186.

Bailey, R. G. (1994). Ecoregions of the United States. Retrieved August 7, 2016, from http://www.fs.fed.us/rm/ecoregions/products/map-ecoregions-united$\underline{\text { states/\# }}$

Beery, T., Stålhammar, S., Jönsson, K. I., Wamsler, C., Bramryd, T., Brink, E., . . Schubert, P. (2016). Perceptions of the ecosystem services concept: Opportunities and challenges in the Swedish municipal context. Ecosystem Services, 17, 123-130.

Birol, F. (2008). World energy outlook. Paris: International Energy Agency.

Boutilier, R., Black, L., \& Thomson, I. (2012). From metaphor to management tool: How the social license to operate can stabilise the socio-political environment for business. International mine management 2012 proceedings, 227-237.

Bronfman, N. C., Jiménez, R. B., Arévalo, P. C., \& Cifuentes, L. A. (2012). Understanding social acceptance of electricity generation sources. Energy Policy, 46, 246-252.

Brown, M. A., \& Sovacool, B. K. (2011). Climate change and global energy security: technology and policy options. Cambridge, MA: MIT Press.

Bull, J., Jobstvogt, N., Böhnke-Henrichs, A., Mascarenhas, A., Sitas, N., Baulcomb, C., . . Z Zähringer, J. (2016). Strengths, weaknesses, opportunities and threats: 
A SWOT analysis of the ecosystem services framework. Ecosystem Services, $17,99-111$.

Caputo, J., Beier, C. M., Groffman, P. M., Burns, D. A., Beall, F. D., Hazlett, P. W., \& Yorks, T. E. (2016). Effects of harvesting forest biomass on water and climate regulation services: a synthesis of long-term ecosystem experiments in eastern North America. Ecosystems, 19(2), 271-283.

Chan, K. M. A., Satterfield, T., \& Goldstein, J. (2012). Rethinking ecosystem services to better address and navigate cultural values. Ecological Economics, 74, 8-18. doi: http://dx.doi.org/10.1016/j.ecolecon.2011.11.011

Chin, H.-C., Choong, W.-W., Alwi, S. R. W., \& Mohammed, A. H. (2014). Issues of social acceptance on biofuel development. Journal of Cleaner Production, $71,30-39$.

Clement, J. M., \& Cheng, A. S. (2011). Using analyses of public value orientations, attitudes and preferences to inform national forest planning in Colorado and Wyoming. Applied Geography, 31(2), 393-400.

Costanza, R. (2008). Letter to the Editor. Ecosystem services: Multiple classification systems are needed. Biological Conservation, 141(2), 350-352.

Costanza, R., \& Folke, C. (1997). Valuing ecosystem services with efficiency, fairness, and sustainability as goals. In G. C. Daily (Ed.), Nature's services: societal dependence on natural ecosystems (pp. 49-70). Washington, DC: Island Press. 
Darvill, R., \& Lindo, Z. (2014). Quantifying and mapping ecosystem service use across stakeholder groups: Implications for conservation with priorities for cultural values. Ecosystem Services.

De Groot, R. S., Alkemade, R., Braat, L., Hein, L., \& Willemen, L. (2010). Challenges in integrating the concept of ecosystem services and values in landscape planning, management and decision making. Ecological Complexity, 7(3), 260-272.

Dillman, D. A., Smyth, J. D., \& Melani, L. (2010). Internet, mail, and mixed-mode surveys: the tailored design method. Toronto: Wiley \& Sons

Donders, A. R. T., van der Heijden, G. J., Stijnen, T., \& Moons, K. G. (2006). Review: a gentle introduction to imputation of missing values. Journal of Clinical Epidemiology, 59(10), 1087-1091.

Downing, M., Eaton, L. M., Graham, R. L., Langholtz, M. H., Perlack, R. D., Turhollow Jr, A. F., . . Brandt, C. C. (2011). US billion-ton update: biomass supply for a bioenergy and bioproducts industry. Oak Ridge, TN: Oak Ridge National Laboratory (ORNL).

Dunlap, R. E., Van Liere, K. D., Mertig, A. G., \& Jones, R. E. (2000). New trends in measuring environmental attitudes: measuring endorsement of the new ecological paradigm: a revised NEP scale. Journal of Social Issues, 56(3), 425-442.

Fazio, R. H. (1989). On the power and functionality of attitudes: The role of attitude. Attitude Structure and Function, 153-179. 
Fishburn, P. C. (1970). Utility theory for decision making. New York: Wiley.

Gasparatos, A., Stromberg, P., \& Takeuchi, K. (2011). Biofuels, ecosystem services and human wellbeing: Putting biofuels in the ecosystem services narrative. Agriculture, Ecosystems \& Environment, 142(3-4), 111-128. doi: http://dx.doi.org/10.1016/j.agee.2011.04.020

Gehman, J., Lefsrud, L. M., \& Fast, S. (2017). Social license to operate: Legitimacy by another name? Canadian Public Administration, 60(2), 293-317.

Goerndt, M. E., D’Amato, A. W., \& Kabrick, J. M. (2014). Forest management for sustainable wood energy feedstock supply. In F. X. Aguilar (Ed.), Wood Energy in Developed Economies: Resource Management, Economics and Policy (pp. 93).

Gossling, S., Kunkel, T., Schumacher, K., Heck, N., Birkemeyer, J., Froese, J., . . Schliermann, E. (2005). A target group-specific approach to "green” power retailing: students as consumers of renewable energy. Renewable and Sustainable Energy Reviews, 9(1), 69-83. doi: http://dx.doi.org/10.1016/j.rser.2004.01.005

Groves, R. M., Fowler Jr, F. J., Couper, M. P., Lepkowski, J. M., Singer, E., \& Tourangeau, R. (2011). Survey methodology (Vol. 561): John Wiley \& Sons.

Gunningham, N., Kagan, R. A., \& Thornton, D. (2004). Social license and environmental protection: why businesses go beyond compliance. Law \& Social Inquiry, 29(2), 307-341. 
Halder, P., Prokop, P., Chang, C.-Y., Usak, M., Pietarinen, J., Havu-Nuutinen, S., . . . Cakir, M. (2012). International survey on bioenergy knowledge, perceptions, and attitudes among young citizens. BioEnergy Research, 5(1), 247-261.

Hauru, K., Eskelinen, H., Yli-Pelkonen, V., Kuoppamäki, K., \& Setälä, H. (2015). Residents' perceived benefits and the use of urban nearby forests. International Journal of Applied Forestry, 2(1), 1-23.

Heberlein, T. A. (2012). Navigating environmental attitudes. New York, NY: Oxford University Press.

Hitchner, S., Schelhas, J., Hujala, T., \& Brosius, J. P. (2014). Public opinion and wood energy. In F. X. Aguilar (Ed.), Wood Energy in Developed Economies: Resource Management, Economics and Policy (pp. 32-74).

Iniesta-Arandia, I., García-Llorente, M., Aguilera, P. A., Montes, C., \& MartínLópez, B. (2014). Socio-cultural valuation of ecosystem services: uncovering the links between values, drivers of change, and human well-being. Ecological Economics, 108, 36-48.

IPCC. (2007). Summary for policymakers, In: Climate Change: 2007: The Physical Science Basis. Contribution of Working Group I to the Fourth Assessment Report for the Intergovernmental Panel on Climate Change. Cambridge, United Kingdom.

IPCC. (2014). Summary for policymakers, In: Climate Change 2014, Mitigation of climate change. In O. Edenhofer, R. Pichs-Madruga, Y. Sokona, E. Farahani, 
S. Kadner, K. Seyboth, A. Adler, I. Baum, S. Brunner, P. Eickemeier, B. Kriemann, J. Savolainen, S. Schlömer, C. v. Stechow, T. Zwickel \& J. C. Minx (Eds.), Contribution of Working Group III to the Fifth Assessment Report of the Intergovernmental Panel on Climate Change. Cambridge, United Kingdom and New York, NY, USA: Cambridge University Press.

Johnson, D. M., Halvorsen, K. E., \& Solomon, B. D. (2011). Upper Midwestern US consumers and ethanol: Knowledge, beliefs and consumption. Biomass and Bioenergy, 35(4), 1454-1464.

Kempton, W., Boster, J. S., \& Hartley, J. A. (1996). Environmental values in American culture. Woburn, MA: MIT Press.

King, G., Keohane, R. O., \& Verba, S. (1994). Designing social inquiry: Scientific inference in qualitative research: Princeton University Press.

Lincoln, A. (2015). Rethinking social licence to operate-A concept in search of definition and boundaries. Environment and Energy Bulletin, 7(2), 1-10.

Lincoln County. (2015). 2015 Annual Report. Retrieved from http://www.co.lincoln.wi.us/i/d/annual 15.rpt.pdf.

Lynch-Wood, G., \& Williamson, D. (2007). The social licence as a form of regulation for small and medium enterprises. Journal of Law and Society, $34(3), 321-341$.

Marciano, J. A., Lilieholm, R. J., Teisl, M. F., Leahy, J. E., \& Neupane, B. (2014). Factors affecting public support for forest-based biorefineries: A comparison 
of mill towns and the general public in Maine, USA. Energy Policy, 75, 301311.

Martín-López, B., Iniesta-Arandia, I., García-Llorente, M., Palomo, I., CasadoArzuaga, I., Del Amo, D. G., .. . Willaarts, B. (2012). Uncovering ecosystem service bundles through social preferences. PloS One, 7(6), e38970.

McMillan, D. W., \& Chavis, D. M. (1986). Sense of community: A definition and theory. Journal of Community Psychology, 14(1), 6-23.

Millennium Ecosystem Assessment. (2005). Ecosystems and human well-being biodiversity synthesis. Washington, DC: World Resources Institute.

Miller, R., \& Acton, C. (2009). SPSS for social scientists: Palgrave Macmillan.

Moffat, K., Lacey, J., Zhang, A., \& Leipold, S. (2016). The social licence to operate: a critical review. Forestry: An International Journal of Forest Research, 89(5), 477-488.

Mozumder, P., Vásquez, W. F., \& Marathe, A. (2011). Consumers' preference for renewable energy in the southwest USA. Energy Economics, 33(6), 11191126. doi: http://dx.doi.org/10.1016/j.eneco.2011.08.003

National Agriculture Statistics Service. (2015). 2015 Cropland data layer statistics for Lincoln County, Wisconsin. Retrieved August 7, 2016, from United States Department of Agriculture https://nassgeodata.gmu.edu/CropScape/ National Research Council and National Academy of Sciences. (2011). Renewable fuel standard: Potential economic and environmental effects of U.S. biofuel policy: Natural Research Council of the National Academies. 
Osborne, J. W., \& Costello, A. B. (2009). Best practices in exploratory factor analysis: Four recommendations for getting the most from your analysis. Pan-Pacific Management Review, 12(2), 131-146.

Peng, C.-Y. J., Lee, K. L., \& Ingersoll, G. M. (2002). An introduction to logistic regression analysis and reporting. The Journal of Educational Research, 96(1), 3-14.

Pires, S. T. (2011). Social perceptions of the biofuel industry in the southeastern US. Master of Science thesis, North Carolina State University.

Plate, R., Monroe, M., \& Oxarart, A. (2010). Public perceptions of using woody biomass as a renewable energy source. Journal of Extension, 48(3), 1-15.

Radics, R. I., Dasmohapatra, S., \& Kelley, S. S. (2016). Public perception of bioenergy in North Carolina and Tennessee. Energy, Sustainability and Society, 6(1), 17.

Reddy, A., Williams, R., \& Johansson, T. (1997). Energy after Rio: Prospects and challenges. United Nations Development Program. New York: United Nations Publications.

Roe, B., Teisl, M. F., Levy, A., \& Russell, M. (2001). US consumers' willingness to pay for green electricity. Energy Policy, 29(11), 917-925. doi: http://dx.doi.org/10.1016/S0301-4215(01)00006-4

Scholte, S. S., van Teeffelen, A. J., \& Verburg, P. H. (2015). Integrating sociocultural perspectives into ecosystem service valuation: A review of concepts and methods. Ecological Economics, 114, 67-78. 
Seppelt, R., Dormann, C. F., Eppink, F. V., Lautenbach, S., \& Schmidt, S. (2011). A quantitative review of ecosystem service studies: Approaches, shortcomings and the road ahead. Journal of Applied Ecology, 48(3), 630-636.

Sherrouse, B. C., Clement, J. M., \& Semmens, D. J. (2011). A GIS application for assessing, mapping, and quantifying the social values of ecosystem services. Applied Geography, 31(2), 748-760.

Singer, C. (2013). Stakeholder Attitudes Toward Forest-Residual Based Biofuels in Washington State. Doctoral dissertation, University of Washington.

Soliño, M., Farizo, B. A., \& Campos, P. (2009). The influence of home-site factors on residents' willingness to pay: An application for power generation from scrubland in Galicia, Spain. Energy Policy, 37(10), 4055-4065.

Solomon, B. D., \& Johnson, N. H. (2009). Valuing climate protection through willingness to pay for biomass ethanol. Ecological Economics, 68(7), 21372144.

Soy-Massoni, E., Langemeyer, J., Varga, D., Sáez, M., \& Pintó, J. (2016). The importance of ecosystem services in coastal agricultural landscapes: Case study from the Costa Brava, Catalonia. Ecosystem Services, 17, 43-52.

Spangenberg, J. H., \& Settele, J. (2010). Precisely incorrect? Monetising the value of ecosystem services. Ecological Complexity, 7(3), 327-337.

Steele, J., Bourke, L., Luloff, A., Liao, P.-S., Theodori, G. L., \& Krannich, R. S. (2001). The drop-off/pick-up method for household survey research. Community Development, 32(2), 238-250. 
Stidham, M., \& Simon-Brown, V. (2011). Stakeholder perspectives on converting forest biomass to energy in Oregon, USA. Biomass and Bioenergy, 35(1), 203-213. doi: http://dx.doi.org/10.1016/j.biombioe.2010.08.014

Susaeta, A., Lal, P., Alavalapati, J., \& Mercer, E. (2011). Random preferences towards bioenergy environmental externalities: A case study of woody biomass based electricity in the Southern United States. Energy Economics, 33(6), 1111-1118. doi: http://dx.doi.org/10.1016/j.eneco.2011.05.015

Thompson, S. C. G., \& Barton, M. A. (1994). Ecocentric and anthropocentric attitudes toward the environment. Journal of Environmental Psychology, $14(2), 149-157$.

U.K. Department for Environment Food and Rural Affairs. (2007). An introductory gudie to valuing ecosystem services. (PB12852). London, U.K.: Retrieved from https://www.gov.uk/government/uploads/system/uploads/ attachment_data/file/69192/pb12852-eco-valuing-071205.pdf.

U.S. Environmental Protection Agency. (2015). National Ecosystem Services Classification System (NESCES): Framework design and policy application. Retrieved October 8, 2018, from https://www.epa.gov/eco-research/nationalecosystem-services-classification-system-framework-design-and-policy University of Wisconsin. (2015). Wisconsin Data Collections GeoData@Wisconsin Robinson Map Library Geospatial Archive. Retrieved April 7, 2015, from https://www.geography.wisc.edu/maplib/gisdataWI.php 
USFS FIA. (2016). Forest inventory data online web-applicaiton version: FIDO 1.51.05d: U.S. Department of Agriculture, Forrest Service, Northern Research Station.

We Energies. (2010). Application to build and operate a biomass-fired cogeneration facility in the Village of Rothschild. (128334). Retrieved from http://psc.wi.gov/apps35/ERF search/content/SearchResult.aspx.

We Energies. (2013, November 11). Our Rothschild biomass cogeneration plant begins commericial operation. Retrieved August 7

2016, from http://weenergies.blogspot.com/2013/11/our-rothschild-biomass$\underline{\text { cogeneration.html }}$

Wegener, D., \& Kelly, J. (2008). Social psychological dimensions of bioenergy development and public acceptance. BioEnergy Research, 1(2), 107-117. doi: $10.1007 / \mathrm{s} 12155-008-9012-\mathrm{z}$

Wüstenhagen, R., Wolsink, M., \& Bürer, M. J. (2007). Social acceptance of renewable energy innovation: An introduction to the concept. Energy Policy, 35(5), 2683-2691.

Zografakis, N., Sifaki, E., Pagalou, M., Nikitaki, G., Psarakis, V., \& Tsagarakis, K. P. (2010). Assessment of public acceptance and willingness to pay for renewable energy sources in Crete. Renewable and Sustainable Energy Reviews, 14(3), 1088-1095. 


\subsection{Chapter 4 Preface}

In the previous chapter, I used the results of a household survey to explore motivating factors of local community support and opposition of woody biomass production for electricity generation. This work demonstrated a methodology to identify local production systems and biomass harvesting effects that influence the social acceptability of forest-based biopower production. These findings suggest that identifying local forest-based ecosystem services of high socio-cultural value and crafting policies to incentivize their protection and/or maximize their benefits would likely lead to more socially accepted biomass production systems at the community level.

In the following chapter, I will examine the use of sustainable forestry management (SFM) certification schemes by governments to source woody biomass for bioenergy production. SFM certification programs have become a popular market-based policy tool to help governments address concerns of deforestation driven by demand for traditional wood products. As international demand for woody biomass for energy production has grown, and governments' willingness to implement command-and-control regulation has declined, some policy makers have turned to biomass certification to address sustainability concerns of woody biomass production and enhance its social acceptance.

In Chapter Four, I will evaluate the United Kingdom's use of two popular SFM certification programs to source woody biomass to achieve its renewable power goals. The reason for the UK focus is because that country has by far the highest 
adoption rate of SFM schemes. Specifically, the study focuses on the Sustainable Forestry Initiative (SFI) and the Forest Stewardship Council (FSC) certification programs and compares the schemes to criteria found in the scholarly literature for sustainable bioenergy feedstock production. The chapter includes a brief overview of literature pertaining to SFM and bioenergy certification schemes followed by a detailed comparison of each scheme based on economic, social and environmental criteria. The chapter concludes with a discussion of the perceived shortcomings of using FSC and SFI to source woody biomass materials and recommendations to reconcile these weaknesses. 


\section{Chapter 4: An Evaluation of the U.K.'s use of SFM Standards to Procure Solid Woody Biomass for Electricity Generation Using Sustainable Bioenergy Criteria ${ }^{6}$}

The threat of climate change and depletion of its fossil fuels has pushed the United Kingdom to aggressively pursue renewable energy sources for power production. According to its National Renewable Energy Action Plan, the U.K. hopes to generate $30 \%$ of its electricity demand by 2020 from renewable sources, with energy from biogenic sources accounting for approximately $22.3 \%$ of renewable generation. The U.K. requires that all woody biomass imported to help meet these renewable electricity goals provide evidence of legal and sustainable sourcing, and at a minimum, save $60 \%$ in GHG emissions compared to fossil fuels. Under its Timber Standard for Heat \& Electricity, the U.K. recognizes woodfuel imported from U.S. forests certified by Sustainable Forestry Initiative (SFI) and Forest Stewardship Council (FSC) as meeting this requirement. This study evaluates SFI and FSC sustainable forest management certification programs using criteria found in the scholarly literature for sustainable bioenergy feedstock production. The author argues that the sustainability of U.K. woody biomass imports for electricity would be improved by coupling sustainable forest management programs with a bioenergy sustainability scheme as designed by the Roundtable on Sustainable Biomaterials.

\footnotetext{
${ }^{6}$ The material contained in this chapter was previously published in Biofuels.
} 


\subsection{Introduction}

The threat of climate change and depletion of its domestic fossil fuels has pushed the United Kingdom to aggressively pursue renewable energy sources for power production. According to its National Renewable Energy Action Plan, the U.K. hopes to generate $30 \%$ of its electricity demand and $12 \%$ of its heating/cooling demand from renewable sources by 2020. The plan's architects anticipate biogenic sources to account for approximately $22.3 \%$ of renewable electricity generation and $63.1 \%$ for renewable heat and cooling (U.K. Department of Energy \& Climate Change, 2010). According to the U.K.'s 2012 Bioenergy Strategy, replacing fossil fuels with woody biomass offers numerous benefits such as reduced greenhouse gas emissions, increased income for woodland owners, and enhanced use of sustainable forest management practices benefiting biodiversity (U.K. Department of Energy \& Climate Change, 2012). In addition, the use of forest biomass has been recognized as a means to enhance domestic energy security and employment opportunities (Stupak et al., 2007).

Since 2009 , the share of domestically sourced woodfuel to meet the U.K.'s renewable electricity and heating/cooling requirements has declined from $92 \%$ to only $52 \%$ in 2012 . The balance has been made up from imported woodfuel (U.K. Department of Energy \& Climate Change, 2013c). The U.K.'s Renewables Obligation $(\mathrm{RO})$ requires all woody biomass imported to meet its renewable electricity goal to be accompanied by evidence of its legal and sustainable sourcing, and at a minimum, save $60 \%$ in GHG emissions compared to fossil fuels. Under 
Category A of its Timber Standard for Heat \& Electricity (derived from the U.K.'s Timber Procurement Policy), the U.K. recognizes woodfuel imported from U.S. forests certified by Sustainable Forestry Initiative (SFI) and Forest Stewardship Council (FSC) as meeting this requirement (U.K. Department of Energy \& Climate Change, 2014b). Collectively, SFI and FSC are responsible for certifying approximately 38.6 million hectares of forestland in the United States (Forest Stewardship Council, 2015; Programme for the Endorsement of Forest Certification, 2014) and this represents nearly $80 \%$ of the total U.S. forestland eligible for renewable energy production under Category A of the U.K. Timber Procurement Policy.

The U.K.'s renewable energy targets, along with other European Union (EU) members' targets, have led to a substantial demand for biomass creating a burgeoning export market for U.S. wood pellets. While much of the demand for biomass in the EU is expected to be derived from domestic sources, estimates still predict that imports will increase nearly $400 \%$ by 2020 from 2010 levels (Lamers et al., 2015). In 2013, global U.S. exports reached 2.7 million metric tons with more than 1.5 million metric tons sent to the U.K. (Hoagland, 2014). The U.K.'s demand for imported biomass pellets for electricity production are expected to grow to 10 million metric tons by 2015 and as much as 20 million tons by 2020 . The vast majority of these additional imports are expected to come in the form of pellets from the U.S. and Canada with the Baltic states and Portugal as additional options (Hogan, 2013). 
The U.K. is not alone in using certification by organizations such as SFI and FSC to approve the use of woody biomass for renewable power production. The majority of states in the U.S. have renewable portfolio standards (RPS) that require a proportion of retail electricity sales to be generated from renewable sources. Some states, like New York, allow for feedstock approval processes to be circumnavigated if generating facilities are able to prove that biomass harvested from land parcels are enrolled in FSC, SFI, or specified alternative programs (New York State Energy Research \& Development Authority, 2014). Other states, such as Maine, have called for using forest management certification schemes as a mechanism to simplify and reduce the complexity of adhering to neighboring states' RPS rules (State of Maine, 2012).

While the increased exports of U.S. woody biomass have, and will continue, to create domestic economic benefits, there are questions related to its environmental and social sustainability. Greater demand for woody biomass can be sourced in the form of post-harvest residuals (e.g. stumps, tree tops and branches), dedicated biomass plantations, and harvesting non-merchantable and small diameter species, and waste wood materials from mills and municipal sources. Enhanced demand for woody biomass may impact traditional forest management practices in the following ways: 1) increased harvesting on previously unmanaged or previously poorly managed forestland to access small diameter species; 2) enhanced removal of residues from forest floors after harvesting operations; and 3) expanded use of shortrotation tree species like hybrid poplar and willow on abandoned agricultural or 
forage lands, using agricultural practices like shorter rotation times and increased use of fertilizers, pesticides and herbicides (Janowiak \& Webster, 2010). Berger et al. (2013) argue that harvesting practices for "energy wood" move beyond the traditional practices of conventional forest management, which attempts to mimic natural disturbances like wild fires and disease. Energy wood harvesting practices, through the removal of stumps, large and fine deadwood, and small-diameter trees effects forest structure even more so than traditional whole-tree harvesting practices. Studies of woody biomass production in the U.S. have shown potential links to increased net GHG emissions compared to fossil fuels, soil and water degradation, and declines in biodiversity (Janowiak \& Webster, 2010; Lattimore et al., 2009).

The social impacts of woody biomass production are much less well understood. According to a comprehensive literature review of forest-biomass sustainability studies by Cambero and Sowlati (2014), no dedicated social sustainability assessment studies have been completed due to the difficult nature of quantifying social impacts of bioenergy production. However, woody biomass production has the potential to impact the social conditions of a production region by influencing its culture, community structure, political systems, health of residents, and personal and property rights (Vanclay, 2003).

Forestry management certification has been proposed as a market-driven alternative to traditional command and control regulation to address the sustainability concerns of wood-based bioenergy production. SFI and FSC are the two most widely recognized certification schemes in the U.S. Neither of these 
programs were designed with bioenergy production in mind; however, the U.K.'s use of Category A suggests that certification ensures the acquired biomass was produced sustainably.

Preventing unsustainable forestry management practices is a critical goal of the U.K.'s woody biomass procurement policy and justifies the use of sustainable forest management (SFM) certification programs designed primarily to prevent overexploitation of forest resources. However, the demand for woody biomass is driven in part by the U.K.'s commitment to meet climate change mitigation goals. Therefor the U.K.'s biomass procurement policy should also be evaluated using bioenergy sustainability criteria that have been developed to ensure the use of biogenic sources contribute to reducing net emissions of GHGs in addition to a plethora of other ecological, social and economic goals. The goal of this study was to review the U.K.'s decision to use SFI and FSC certification programs as a mechanism to source sustainable woody biomass for bioenergy production. The following section of this paper will discuss the basic goals and criticisms of current forestry certification schemes. Then a list of bioenergy system sustainability criteria drawn from the literature on sustainable biomass feedstock production will be presented and used to evaluate the SFI and FSC programs in order to identify gaps in the schemes' ability to assess the sustainability of woody biomass production. A discussion will follow focusing on key criteria omissions and potential recommendations for the U.K. biomass procurement policy. 


\subsection{Literature Review}

\subsubsection{Addressing Sustainability through Certification}

An alternative to direct command and control regulation, certification schemes offer a market-based strategy that encourages producers of a given commodity to adhere to voluntary standards in return for formal recognition of meeting said requirements through recognizable labeling. ${ }^{7}$ Certification schemes have become a popular strategy for mitigating numerous sustainability challenges including bioenergy feedstock production and SFM. The underlying premises of sustainability certification as a form of non-state market driven-governance are: 1) certification gains authority through voluntary adoption as opposed to coercive state authority; 2) institutions such as certification standards are adaptable and change over time through learning and inclusion of different stakeholder groups; 3) standards require firms to take actions that would otherwise be avoided due to negative impacts to profit margins; 4) firms at the end of the supply chain seek to demonstrate their commitment to meet societal demand for sustainably produced goods by selling certified products; 5) upstream suppliers will participate in certification program in order to access to downstream retail markets; and 6) some form of verification is conducted to ensure that producers actually adopted the required certification practices (Cashore et al., 2007).

\footnotetext{
${ }^{7}$ For an in-depth discussion of the certification process see: Lewandowski, I., \& Faaij, A. P. C. (2006). Steps towards the development of a certification system for sustainable bio-energy trade. Biomass and Bioenergy, 30(2), 83-104.
} 
Forest certification came into vogue in the early 1990s following concerns of rainforest deforestation and subsequent loss of biodiversity and carbon sequestration capacity (Rametsteiner \& Simula, 2003). Forest certification builds upon the use of criteria and indicators developed by regional and national governments to broadly assess environmental and socioeconomic SFM goals of forest resources within their boundaries. SFM practices develop criteria and indicators that focus on reconciling competing interests related to demands placed on forest resources focusing on, but not limited to: extent of forest resources, forest health and vitality, productive forest functions, biological diversity, protective functions of forests, socio-economic benefits and needs, legal, and policy and institutional frameworks (Rametsteiner \& Simula, 2003). Where SFM focuses on national/sub-national public goals, forest certifications are market driven and focus on forest management units (FMU), which can vary in size and composition; however, forest certification programs often derive many of their criteria and indicators from SFM policies.

The dominant SFM programs in the U.S. are FSC and SFI. SFI is the largest single source forestry certification program in the world and is one of two U.S.endorsed members of the international meta-standard certification organization, the Program for the Endorsement of Forest Certification (PEFC) schemes (the other member being the American Tree Farm System). SFI is responsible for nearly 24.3 million hectares of certified forests in the U.S. with an additional 75.8 million hectares certified in Canada (Programme for the Endorsement of Forest Certification, 2014). The FSC was established in 1993 following the Earth Summit in Rio de 
Janeiro that focused more on the issue of global climate change and failed to adequately address the increasing deforestation. The FSC formed in order to develop a market-based solution to deforestation with a goal of ensuring that forest products come from environmentally, socially, economically sustainable forests (Forest Stewardship Council, 2013). Today, FSC operations are found in more than 80 countries, with nearly than 70 million hectares of certified forests in the U.S. (14.3 million ha) and Canada (55.7 million ha) as of 2014 (Forest Stewardship Council, 2015).

Several studies have compared the strengths of notable SFM certification programs such as SFI and FSC. A meta-analysis indicates that FSC's certification program placed more emphasis on social and ecological sustainability criteria than SFI and the Canadian Standards Association's Sustainable Forestry Management program (Clark \& Kozar, 2011). This finding supported a study conducted by Sample et al. (2003), in which public forest management agencies conducted "reverse evaluations" of SFI and FSC programs' impact on sustainable management of their forests. The study found that FSC placed a stronger emphasis on social and ecological issues compared to SFI. SFI places more emphasis on maintaining the usable lifespan of tree stands for the purpose of the owner's financial wellbeing than FSC, but FSC required forest managers to adopt practices that enhanced social and ecological sustainability (Clark \& Kozar, 2011). A recent study has shown that both North American certification schemes require forest managers to adopt a number of changes to their management practices. However, FSC adopters are required to make 
more environmental and forest management practices, while SFI requires more changes to economic and management systems (Moore et al., 2012).

Few studies analyze the direct sustainability impact of SFM certification programs using primary data or field studies, and even fewer studies actually compare SFM programs' results on the ground (Visseren-Hamakers \& Pattberg, 2013). However, limited studies suggest that forest certification has helped to alter environmental, social and economic sustainability of forest management practices, and forest managers believe that certification benefits outweigh its disadvantages (Moore et al., 2012). A study on the impact of FSC certification in Indonesia suggests numerous societal benefits such as reduced deforestation, air pollution, firewood dependence, respiratory infections, and malnutrition (Miteva et al., 2015), while another study provided evidence that FSC certification helped to improve the ecological conditions of Mediterranean streams. Another study showed that FSC certification helped to increase procedural and contextual equity within certified firms in Brazil (Pinto \& McDermott, 2013). FSC-certified forests in Tanzania were shown to enhance forest structure, regeneration, economic benefits to communities and lower fire incidences compared to non-FSC certified forests (Kalonga et al., 2015). Another study found evidence a PEFC) endorsed certification programs helped to improve forest management systems in Malaysia (Lewis \& Davis, 2015).

Forestry certification schemes have been criticized for several reasons. One of the primary complaints levied at the FSC certification process is that program participants report lower than expected price premiums and access to new markets 
(Overdevest \& Rickenbach, 2006). In addition, high costs of certification, limited ability to prevent illegal logging, and the inability to protect biodiversity are also cited (Schepers, 2010). Humphries and Kainer (2006) also concluded that certification costs are prohibitive to non-industrial private forest owners and also cited the complexity of certification as being a barrier to scheme adoption. Competitive advantages for larger firms in developed countries are often achieved when certification requirements are established (Pinto \& McDermott, 2013). Achieving certification often requires high capital and knowledge requirements - $\mathrm{a}$ disadvantage for smaller forest management organizations. Often timber producers in developing countries, who would have a market advantage due to low labor costs, find it difficult to achieve these standards, while forest owners in developed countries are able to do so (Auld et al., 2008). Another flaw relates to the overwhelming competition in certification market share. With so many certification programs available, a "race to the bottom" in order to attract participants threatens the validity of the certification industry, especially if the most stringent standards fail to attract a premium for their certify products in the market place (Auld et al., 2008). A survey of forest product manufactures in The U.S. State of Virginia suggested that participation in certification programs offered marginal improvements to company image, market share, future, demand, exports, or any other competitive advantage (Bond et al., 2014). A separate survey of U.S. hardwood lumber manufactures indicated that only $25 \%$ or respondents reported realizing financial benefits from participating in chain-of-custody certification (Espinoza et al., 2012). 
Even though forestry and bioenergy feedstock certification schemes have similar sustainability goals and woody biomass is increasingly relied upon for bioenergy production, the two differ in important ways. Bioenergy schemes have been driven by climate change and energy security, while forestry schemes have been driven by sustainable management of forests (Scarlat \& Dallemand, 2011). Bioenergy schemes have placed a heavier emphasis on concepts such as energy return on investment, GHG balances, and air quality than forest certification schemes (Scarlat \& Dallemand, 2011). This was contradicted in part by an analysis done by Stupak et al., who found that two largest forest certification programs (Forest Stewardship Council and the Programme for the Endorsement of Forest Certification) did not directly address standards for the bioenergy industry; however, many of the sustainability criteria required for bioenergy were indirectly addressed (Stupak et al., 2011). Nonetheless, both studies called for a higher level of integration between forest and bioenergy certification schemes as energy systems place a greater demand on wood resources.

\subsection{Review Criteria}

The assessment framework developed through an expert survey conducted by Buchholz et al. (2009) and later revisited by Markevičius et al. (2010) was used to evaluate the ability of current forestry product certification schemes to ensure the sustainability of woody biomass feedstocks for bioenergy production. The original study on bioenergy system sustainability identified 35 environmental, social, and 
economic criteria from the academic literature. This list was chosen over other criteria sets developed specifically for woody biomass such as the one developed by Lattimore et al. (2009), because Buchholz et al.'s work provides a comprehensive and diverse array of criteria that enables the thorough evaluation of all three legs of the sustainability stool. Their survey work found that the majority of the 35 suggested criteria were rated important by a sample of experts within each stage of the bioenergy supply chain. Indeed, none of the criteria evaluated received a rating of low importance by more than $30 \%$ of respondents. This indicates that all the criteria proposed by the authors received a rating of medium or higher by the majority of those surveyed and are considered valid sustainability criteria for bioenergy systems.

For the purpose of this study, only 34 criteria of the original 35 criteria were used in this analysis. The criterion of "food security" was removed since forest biomass production has little connection to issues of food production in the U.S. Removing this criterion left 14 criteria focused on social concerns, 17 focused on environmental concerns, and four focused on economic concerns. A list of criteria and criterion explanations are provided in Table 18, 19 and 20. 
Table 18: Social sustainability criteria

\begin{tabular}{|c|c|}
\hline Social criteria & Explanation \\
\hline Acceptance & $\begin{array}{l}\text { Acceptance of production methods by producer } \\
\text { and consumer }\end{array}$ \\
\hline Standard of Living & $\begin{array}{l}\text { Increased access to services such as food, water, } \\
\text { shelter, energy }\end{array}$ \\
\hline $\begin{array}{l}\text { Compliance with laws and international } \\
\text { agreements }\end{array}$ & $\begin{array}{l}\text { Compliance with local, state, federal laws and } \\
\text { international treaties }\end{array}$ \\
\hline Public participation & $\begin{array}{l}\text { Incorporation of stakeholders in decision making, } \\
\text { public input }\end{array}$ \\
\hline Respect for human rights & Education, security, liberty, health \\
\hline $\begin{array}{l}\text { Land availability for other human } \\
\text { activities than food production }\end{array}$ & $\begin{array}{l}\text { Feedstock production did not limit other forest uses } \\
\text { beyond food production }\end{array}$ \\
\hline Respect of land tenure \& tight of use & $\begin{array}{l}\text { Respect of customary and legal land tenure and } \\
\text { right of use }\end{array}$ \\
\hline Monitoring of criteria performance & Criteria monitored \\
\hline Noise impacts & Noise of harvesting, transportation, etc. \\
\hline Planning & $\begin{array}{l}\text { Management plan required, criteria included in } \\
\text { management plan }\end{array}$ \\
\hline Respecting minorities & $\begin{array}{l}\text { Rights of minorities, women, children, elderly } \\
\text { respected }\end{array}$ \\
\hline Social cohesion & $\begin{array}{l}\text { Equity concerns, migration and settlement } \\
\text { concerns }\end{array}$ \\
\hline Working conditions \& labor rights & $\begin{array}{l}\text { Safe working conditions, respect for labor laws, } \\
\text { working hours, etc. }\end{array}$ \\
\hline
\end{tabular}


Table 19: Environmental sustainability criteria

\begin{tabular}{|l|l|}
\multicolumn{1}{|c|}{ Environmental criteria } & \multicolumn{1}{c|}{ Explanation } \\
\hline $\begin{array}{l}\text { Adaptation capacity to } \\
\text { environmental hazards and climate } \\
\text { change }\end{array}$ & $\begin{array}{l}\text { Feedstock diversification and knowledge of feedstock site } \\
\text { demand }\end{array}$ \\
\hline Crop diversity & Understanding and evaluation of monoculture systems \\
\hline Ecosystem connectivity & Preventing habitat fragmentation \\
\hline Ecosystem protection & Protection of high valued or rare ecosystems \\
\hline Energy balance & $\begin{array}{l}\text { Efficient use of energy inputs, positive energy return on } \\
\text { investment (EROI) }\end{array}$ \\
\hline Exotic species applications & $\begin{array}{l}\text { Evaluation of risks related to introduction of non-native } \\
\text { species }\end{array}$ \\
\hline Greenhouse gas balance & Evaluation of $\mathrm{CO}_{2}, \mathrm{CH}_{4}, \mathrm{~N}_{2} \mathrm{O}, \mathrm{CFCs}$ \\
\hline Land use change (Deforestation) & Impact of land conversion \\
\hline Landscape view & Visual impact of feedstock production on local landscape \\
\hline Natural resource efficiency & Efficient use of natural resources \\
\hline $\begin{array}{l}\text { Other hazardous atmospheric } \\
\text { emissions other than GHGs }\end{array}$ & Emissions of $\mathrm{SO} 2, \mathrm{CO}, \mathrm{NO}_{\mathrm{x}}$, and particulates \\
\hline Soil systems protection & $\begin{array}{l}\text { Protection against biological, chemical, physical, } \\
\text { degradation, desertification }\end{array}$ \\
\hline Species protection & endangered or high valued species protected \\
\hline $\begin{array}{l}\text { Use of chemicals, pest control, and } \\
\text { fertilizer }\end{array}$ & $\begin{array}{l}\text { Environmental and human health affects minimized or } \\
\text { eliminated }\end{array}$ \\
\hline $\begin{array}{l}\text { Use of genetically modified } \\
\text { organisms }\end{array}$ & Abide by federal laws, take risks into account \\
\hline Waste management & $\begin{array}{l}\text { Waste streams are reduced, harmful waste disposed of } \\
\text { properly }\end{array}$ \\
\hline Water quality & Surface and ground water quality and quantity protected \\
\hline Source: (Buchholz et al., 2009; Markevičius et al., 2010) \\
\hline
\end{tabular}

Table 20: Economic sustainability criteria

\begin{tabular}{|l|l|}
\hline \multicolumn{1}{|c|}{ Economic criteria } & \multicolumn{1}{c|}{ Explanation } \\
\hline Economic stability & $\begin{array}{l}\text { Projects are long term, insulated against market shifts, } \\
\text { product diversification }\end{array}$ \\
\hline Generation of jobs & jobs created, generated jobs are of good quality \\
\hline Macroeconomic sustainability & $\begin{array}{l}\text { local economic development, changes in overall productivity, } \\
\text { flow of capital, foreign investment }\end{array}$ \\
\hline Microeconomic sustainability & $\begin{array}{l}\text { Viability of the business, minimize costs and enhance } \\
\text { profitability }\end{array}$ \\
\hline Source: (Buchholz et al., 2009; Markevičius et al., 2010) \\
\hline
\end{tabular}


A single criteria list was used even though bioenergy from woody biomass feedstocks can take many forms (i.e. electricity, heat and liquid transportation fuels). The primary reason for this is that sustainability goals for woody biomass feedstock production do not change based on the final form of energy that is produced. The criteria outlined above have broad definitions and are not energy-form specific. For example, the importance of creating jobs or ensuring water quality while producing woody biomass does not change if the wood will be used for heat or for transportation fuels. Adhering to legal requirements and minimizing chemical usage are appropriate goals no matter the energy use.

The FSC and SFI certification programs were reviewed to see if and to what extent each scheme incorporated the above criteria. For the purpose of this review, the FSC-US Forest Management Standard v1.0 (Forest Stewardship Council, 2010) and the SFI 2015-2019 Forest Management Standard (Sustainable Forestry Initiative, 2015) certification guideline documents were used to determine if the feedstock sustainability criteria are incorporated into the schemes. Each certification scheme includes a list of normative principles that are used as guidance to establish benchmarks that feedstock producers are required to meet to obtain certification. These principles are often too broad (protect biodiversity) and vague (manage water systems) to evaluate objectively; therefor, this review primarily relied upon certification scheme criteria (FSC) and performance measurements (SFI) when available that are more specific. 
Text analysis was used to determine when each SFM standard included each sustainability criterion. Key word searches within the document where used to identify if and when a criterion was covered. In many cases, it was necessary for the author to infer to the best of his ability to determine if a criterion was adequately included. This necessarily introduced some subjectivity into the final results.

\subsection{Results}

As one would expect, the two certification schemes varied in the integration of the 34 sustainable bioenergy feedstock criteria listed above. Both forestry certification schemes fall short in critical bioenergy feedstock sustainability areas. Overall, SFI failed to address 11 of the 34 bioenergy sustainability criteria identified in this study (nearly $32.4 \%$ ) while FSC failed to address 5 of the 34 (14.7\%). While this comparison is an imperfect metric to assess either scheme's capacity to assess sustainable biomass production, it does provide evidence that FSC incorporates a wider breadth of sustainability criteria than SFI. This trend holds across environmental, social, and economic bioenergy sustainability criteria. This section will highlight the criteria that were not addressed and then distinguish the level of incorporation within each scheme. 


\subsubsection{Environmental Sustainability Criteria}

Table 21 indicates which environmental sustainability criteria were included in each SFM framework and where the criteria can be found in the certification scheme standards. In all, FSC addressed 14 of the 17 criteria while SFI addressed 11 of the 17. Neither scheme made an attempt to address adaptation capacity to environmental hazards and climate change directly. According to Buchholz et al. (2009) and Markevicius et al. (2010), the criterion focuses on feedstock diversification and available knowledge of site demand of feedstocks. Both schemes do discus feedstock diversification but this is primarily in the context of economic diversification and biodiversity with little emphasis on climate change adaptation. In addition, neither scheme addressed energy balances of biomass production processes, total or net balance of GHG emissions, or emissions hazardous non-GHG atmospheric pollutants such as particulate matter.

The SFI scheme does not reference crop diversity or specifically address plantation systems and their ecological impacts. However, FSC's certification scheme places a strong emphasis on crop diversity, its impact on species and ecosystems, and its role in economic sustainability. While it doesn't necessarily forbid monoculture systems (allowed somewhat under strict conditions outlined in C6.10), it discusses ways to encourage ecological biodiversity in scheme criterion C10.3, specifically expressing that even plantations should include diversity related to "the size and spatial distribution of management units within the landscape, number and genetic composition of species, age classes and structures." 
SFI also fails to include an assessment of the impact of biomass production on ecosystem service connectivity which can be affected through fragmentation caused by forest management related activities. FSC covers this criterion in $\mathrm{C} 6.5$, C10.2, and C10.5. Indicator 6.5.d (for C6.5) requires that transportation system design, construction and maintenance specifically reduce and minimize short and long-term habitat fragmentation. Unneeded roads are required to be closed and rehabilitated and area converted to roads, skid trails and landings are expected to be minimized. C10.2 specifically outlines that the design and layout of plantations promote wildlife corridors consistent with patterns of forest stands within the natural landscape. Furthermore, C10.5, indicator 10.5.a provides guidance for the restoration of forests and/or plantations to native ecosystem conditions at the stand or landscape level which has the potential to remediate some disturbances to ecosystem connectivity. 
Table 21: Forestry certification scheme inclusion of bioenergy environmental sustainability criteria

\begin{tabular}{|c|c|c|}
\hline Environmental criteria & $\begin{array}{l}\text { SFI Performance } \\
\text { Measurements }\end{array}$ & FSC Criteria \\
\hline $\begin{array}{l}\text { Adaptation capacity to environmental } \\
\text { hazards and climate change }\end{array}$ & - & - \\
\hline Crop diversity & - & C6.10, C10.3 \\
\hline Ecosystem connectivity & - & C6.5, C10.2, C10.5 \\
\hline Ecosystem protection & $\begin{array}{l}1.2 ; 2.4 ; 3.1 ; 3.2 ; 4.1 ; \\
4.3\end{array}$ & $\begin{array}{l}\text { C5.5; C6.1; C6.2; C6.3; } \\
\text { C6.4, C6.5; C6.6; C6.8, } \\
\text { C10.2; C10.3, C10.5; } \\
\text { C10.6; C10.7 }\end{array}$ \\
\hline Energy Balance & - & - \\
\hline Exotic species applications & $2.1 ; 4.1$ & C6.9; C10.4; C10.7 \\
\hline Greenhouse gas balance & - & - \\
\hline Land use change (Deforestation) & $1.3 ; 2.1 ; 11.2$ & $\begin{array}{l}\text { C6.10; C10.2, C10.5, } \\
\text { C10.9 }\end{array}$ \\
\hline Landscape view & $4.1 ; 5.1 ; 5.2 ; 5.3 ; 11.2$ & C7.1 \\
\hline Natural resource efficiency & $7.1 ; 11.2$ & C5.6 \\
\hline $\begin{array}{l}\text { Other hazardous atmospheric } \\
\text { emissions other than GHGs }\end{array}$ & - & - \\
\hline Soil Systems Protection & $2.3 ; 7.1$ & $\begin{array}{l}\text { C6.1; C6.5, C6.6; C8.2; } \\
\text { C10.6 }\end{array}$ \\
\hline Species protection & $\begin{array}{l}1.2 ; 2.1 ; 2.2 ; 4.1 ; 4.2 ; \\
4.3 ; 11.2\end{array}$ & C6.1; C6.2 \\
\hline $\begin{array}{l}\text { Use of chemicals, pest control, and } \\
\text { fertilizer }\end{array}$ & 2.2 & C6.5; C6.6; C6.7; C10.6 \\
\hline $\begin{array}{l}\text { Use of genetically modified } \\
\text { organisms }\end{array}$ & SFI Policy (pg 3) & C6.8 \\
\hline Waste management & $7.1 ; 11.2$ & C5.3; C6.7 \\
\hline Water quality & $2.2 ; 3.1 ; 3.2 ; 11.2$ & $\begin{array}{l}\text { C5.5; C6.1; C6.5; C6.7, } \\
\text { C8.2; C10.6 }\end{array}$ \\
\hline
\end{tabular}

\subsubsection{Social Sustainability Criteria}

Table 22 provides information on where each bioenergy social sustainability criteria can be found in the SFI and FSC certification scheme standards. Of the 14 social bioenergy sustainability criteria, SFI failed to address three, while FSC failed to address one. Neither scheme provided specific goals for alleviating the ill effects of 
poverty through enhancing access to services like shelter or energy through an assessment of the standard of living of local community members or forest management employees. FSC's C4.1 focuses on local job opportunity development, and if followed, this has the potential to enhance the standard of living for local employees. However, it doesn't seek to enhance the community's standard of living aside from direct employees. SFI's performance measure 7.1 includes an indicator to monitor the use of harvest residues in consideration of economic, social and environmental factors. This could include the use of firewood for heat and cooking, but it isn't explicit in the standard.

The SFI scheme makes no reference to managing noise pollution while FSC acknowledges that noise pollution is one of many social concerns that should be considered when incorporating stakeholder input into forest management plans (C4.4). No guidance is provided on how timber producers are to actually mitigate noise pollution; however, this impact is expected to be mitigated if it is identified as an issue of concern during the social impact assessment process. Additionally, SFI does not include criteria to address social cohesion, which refers to concerns of societal inequity or outward/inward migration caused by biomass production. FSC's C4.1 specifically outlines that local communities adjacent to forest management areas be given opportunities for high quality employment opportunities with equitable and fair wages. If adhered to, this criterion could help to prevent outward migration from rural areas by development local job opportunities. 
Table 22: Forestry certification scheme inclusion of bioenergy social sustainability criteria.

\begin{tabular}{|l|l|l|}
\multicolumn{1}{|c|}{ Social criteria } & \multicolumn{1}{c|}{$\begin{array}{c}\text { SFI Performance } \\
\text { Measurements }\end{array}$} & \multicolumn{1}{c|}{ FSC Criteria } \\
\hline Acceptance & $\begin{array}{l}4.3 ; 5.1 ; 5.2 ; 5.3 ; 5.4 ; \\
6.1 ; 11.2 ; 12.3 ; 13.1\end{array}$ & C 3.4, C6.1; C9.1; C9.2; 9.3 \\
\hline Standard of living & - & - \\
\hline $\begin{array}{l}\text { Compliance with laws and } \\
\text { international agreements }\end{array}$ & $3.1 ; 9.1 ; 9.2$ & $\mathrm{C} 1.1 ; \mathrm{C} 1.3 ; \mathrm{C} 1.5 ; \mathrm{C} 4.2$ \\
\hline Public participation & $6.1 ; 12.1 ; 13.1$ & $\mathrm{C} 4.4, \mathrm{C} 9.2$ \\
\hline Respect for human rights & $2.2 ; 8.1$ & $\mathrm{C} 4.2 ; \mathrm{C} 4.3 ; \mathrm{C} 4.4 ; \mathrm{C} 6.6$ \\
\hline $\begin{array}{l}\text { Land availability for other } \\
\text { human activities than food } \\
\text { production }\end{array}$ & 5.4 & $\begin{array}{l}\mathrm{C} 2.1 ; \mathrm{C} 2.2 ; \mathrm{C} 4.4 ; \mathrm{C} 5.4 ; \\
\mathrm{C} 5.5 ;\end{array}$ \\
\hline $\begin{array}{l}\text { Respect of land tenure \& right } \\
\text { of use }\end{array}$ & $8.2 ; 8.3$ & $\mathrm{C} 2.1 ; \mathrm{C} 2.2 ; \mathrm{C} 2.3 ; \mathrm{C} 3.2$ \\
\hline $\begin{array}{l}\text { Monitoring of criteria } \\
\text { performance }\end{array}$ & $14.1 ; 14.2 ; 15.1$ & $\begin{array}{l}\mathrm{C} 7.2, \mathrm{C} 8.1, \mathrm{C} 8.2 ; \mathrm{C} 8.3, \\
\mathrm{C} 8.4, \mathrm{C} 8.5, \mathrm{C} 9.4 ; \mathrm{C} 10.8\end{array}$ \\
\hline Noise impacts & - & $\mathrm{C} 4.4$ \\
\hline $\begin{array}{l}\text { Planning } \\
\text { Respecting minorities }\end{array}$ & $1.1 ; 4.1$ & $\begin{array}{l}\mathrm{C} 4.4, \mathrm{C} 7.1, \mathrm{C} 7.2, \mathrm{C} 7.3, \\
\mathrm{C} 7.4 ; \mathrm{C} 9.1 ; \mathrm{C} 9.3 ; \mathrm{C} 10.1\end{array}$ \\
\hline Social cohesion & 9.2 & $\mathrm{C} 3.1, \mathrm{C} 3.3, \mathrm{C} 4.1 ; \mathrm{C} 4.4$ \\
\hline $\begin{array}{l}\text { Working conditions \& labor } \\
\text { rights }\end{array}$ & $2.2 ; 9.2 ; 11.2$ & $\mathrm{C} 4.1$ \\
\hline
\end{tabular}

\subsubsection{Economic Sustainability Criteria}

For the economic sustainability criteria, it was determined that FSC covered all four while SFI covered two. Both SFM standards provided criteria to guide economic stability (project longevity) and microeconomic sustainability (profitability) of a project. SFI does not specifically require or assess employment generation or give special priority to job creation in communities near forest management areas. In contrast and described previously, FSC's C4.1 specifically outlines the need to create high value job opportunities for the local communities and requires fair 
compensation for those positions. SFI also fails to address issues of macroeconomic sustainability which refers to issues of local economic development and inflow of capital within the forest management area. FSC explicitly addresses this in C5.4 which states that "Forest management should strive to strengthen and diversify the local economy..." Indicators are developed in order for the forest owner or manager to assist in developing existing and potential markers for timber and non-timber forest products and services like recreation, ecotourism, hunting fishing, etc. A comparison of how SFI and FSC incorporate economic sustainability criteria can be found in Table 23.

Table 23: Forestry certification scheme inclusion of bioenergy economic sustainability criteria.

\begin{tabular}{|l|l|l|}
\multicolumn{1}{|c|}{ Economic criteria } & \multicolumn{1}{c|}{$\begin{array}{c}\text { SFI Performance } \\
\text { Measurements }\end{array}$} & \multicolumn{1}{c|}{ FSC Criteria } \\
\hline Economic stability & $1.1 ; 1.2 ; 11.2 ; 2.4$ & $\mathrm{C} 10.3$ \\
\hline Generation of jobs & - & $\mathrm{C} 4.1$ \\
\hline Macroeconomic sustainability & - & $\mathrm{C} 5.4 ;$ \\
\hline Microeconomic sustainability & 7.1 & $\mathrm{C} 5.1 ; \mathrm{C} 5.2$ \\
\hline
\end{tabular}

\subsection{Discussion}

The results of this study indicate that SFI and FSC SFM programs for the U.S. lack fundamental criteria necessary to guide sustainable biomass production and are fundamentally inappropriate tools to ensure that sustainable woody biomass enters the U.K. This study reflects similar findings by studies analyzing the appropriateness of using SFM programs for sustainable bioenergy production (Gan \& Cashore, 2013; Sikkema et al., 2014; Stupak et al., 2011). Inherently, forestry 
certification schemes are primarily designed to offer a non-state market driven means to limit deforestation. Both forestry schemes go beyond this goal by establishing criteria that seeks to address environmental, social and economic sustainability related to timber management practices. In contrast, the primary goal of bioenergy feedstock systems is to mitigate global climate change. Bioenergy system sustainability criteria are designed so that feedstock production meets this end without negatively impacting (or in many cases enhancing) environmental, social, and economic sustainability. Organizations such as the Roundtable on Sustainable Biomaterials (RSB), International Sustainability \& Carbon Certification (ISCC), Round Table on Responsible Soy (RPS), and Roundtable on Sustainable Palm Oil (RSPO) have created certification programs that used market-based strategy to encourage the sustainable production of various crops that can, in addition to other purposes, be used as biofuel feedstocks (Moser et al., 2014). In addition, bioenergy certification schemes have focused on issues such as indirect land use change, biodiversity loss, food security, and increased GHG emissions (Scarlat \& Dallemand, 2011). This difference in primary goals (climate change mitigation versus deforestation mitigation) explains why the forestry certification schemes fail to include critical criteria related to bioenergy sustainability like minimizing GHG emissions or considering $\mathrm{EROI}^{8}$ when choosing production and transportation methods.

\footnotetext{
${ }^{8}$ A ratio used to evaluate the amount of usable energy gained divided by the amount of energy used to produce bioenergy (or another energy sources). An EROI ratio greater than 1.0 indicates a positive energy return while a ratio less than one indicates a negative energy return [32].
} 
RSB is generally recognized as one of the most comprehensive sustainability standards for bioenergy production (Solomon et al., 2015). This standard includes several important criteria missing from the two SFM certification programs reviewed in this paper such as GHG emissions reductions and air toxic emissions (Solomon et al., 2015), in addition to indirectly addressing issues of system energy balance in its standard Principle 11, criterion E.2 by emphasizing waste reduction in various bioenergy production processes (Roundtable for Sustainable Biomaterials, 2011). RSB's standard also includes Principle 5 focusing on rural and social development in impoverished regions and requires feedstock production operations to assist in improving local stakeholders' socioeconomic status. One option to fulfill this requirement is to assist in the establishment of local clinics, homes, hospitals and schools which would address the "standard of living" criterion not found in either SFI or FSC. However, its limited uptake is a major limitation as a means to certify biomass feedstocks. As of 2014, only four RSB certificates had been issued in the U.S. and two in Canada. In comparison, the ISCC is more popular in North America with a total of 53 certificates issued in the U.S. and seven issued in Canada (only one certificate for each program had been issued in Mexico) (Solomon et al., 2015).

Previous work by Gan \& Cashore (2013) discussed the need to couple SFM programs and bioenergy certification because of the growing use of wood resources for bioenergy production. Their work outlined three options for achieving this goal: 1) incorporating bioenergy certification directly into schemes such as SFI \& FSC; 2) create partnerships between SFM programs and bioenergy certification programs, 
where the former focuses primarily on feedstock production and the latter focuses on issues of conversion; and 3) mutual referencing between bioenergy and SFM programs, where a bioenergy certification program accepts products certified by a recognized SFM program. Ideally, an all-inclusive certification program that's capable of covering both SFM and bioenergy sustainability goals (the first option described by Gan and Cashore) would be developed in order to reduce the need for biomass producers to certify their products with multiple programs. In this option, SFM criteria and indicators would be updated to cover relevant bioenergy sustainability issues and woody biomass for bioenergy production classified as a specific product group under these standards (Stupak et al., 2011). However, this would require SFM programs to make fundamental changes to their certification programs which may be costly and time consuming for the programs and unnecessary given the availability of other certification schemes designed specifically for sustainable bioenergy production. In addition, standards may have a lack of capacity to address bioenergy sustainability concerns or limited support among stakeholder groups within each SFM program (Stupak et al., 2011).

Given the lack of critical bioenergy sustainability criterion inclusion in SFM programs, the U.K. should require that imported woody biomass also include certification by a bioenergy sustainability standard such as RSB or ISCC. The second and third options described by Gan and Cashore (2013) seek to find efficient ways to integrate bioenergy certification and SFM certification programs. While those two options are more feasible, they fail to take into account the holistic nature 
of the biomass supply chain. Bioenergy sustainability criteria such as energy return on investment (EROI) and greenhouse gas emissions are affected throughout the supply chain and not just during the conversion, distribution, and consumption phases that would be governed by the bioenergy certification program. Biomass production practices (which would be under the SFM program's realm) influence net GHG emissions and energy inputs along with other social and economic aspects of bioenergy production. Compartmentalizing the certification process by way of biomass production and conversion (option two) or mutual referencing (option three) fails to take these complexities into account. Therefore, higher levels of cooperation would be needed between the SFM and bioenergy certification programs so that the auditing process takes into account issues of GHGs, EROI, air emissions, etc. throughout the production chain. For example, higher levels of integration could be achieved by requiring biomass producers certified under SFI or FSC to also demonstrate GHG emission reductions by using RSB's GHG lifecycle calculator (discussed in further detail later in this section). Alternatively, the U.K. could require dual certification by an SFM program and a bioenergy sustainability program. This is perhaps the simplest route for policymakers and requires no changes to SFM or bioenergy standards. However, it would place a higher burden on biomass producers to navigate through two separate certification processes.

It is possible to argue that the U.K.'s minimum GHG saving threshold for use solid forest biomass is sufficient, making a second bioenergy sustainability certification unnecessary. But the means by which the U.K. address biomass 
production GHG emissions would be improved by requiring certification by a program like RSB. In addition to meeting Timber Standards, power plants 50KW or larger in the U.K. producing biomass generated electricity must, at a minimum, save $60 \%$ in GHG emissions compared to fossil fuels (U.K. Department of Energy \& Climate Change, 2013b), and electricity from solid biomass receiving RO credits must have a GHG emission intensity under $200 \mathrm{kgCO}_{2} \mathrm{e} / \mathrm{MWh}$ (U.K. Department of Energy \& Climate Change, 2013a). However, the U.K. allows for different GHG calculations requirements depending on the solid biomass fuel classification (e.g. forestry and processing residues, products, wastes, etc.). Solid biomass materials classified as products include pellets produced from short-rotation forestry, and the RO requires a full GHG lifecycle assessment to ensure GHG emission targets are met. Operators can choose to use default values to calculate the carbon intensity of the biomass (U.K. Office of Gas and Electricity Markets, 2014). However, a recent report by the U.K.'s Department of Energy \& Climate Change (DECC) analyzing the GHG emission impacts and EROI of importing woody biomass from North America using life cycle analysis (U.K. Department of Energy \& Climate Change, 2014a). The report indicates that GHG intensity vary depending on the biomass sources, existing carbon stock and distance needed to transport the biomass. Carbon intensities of using both residues and roundwood have the capacity to greatly exceed a carbon intensity of $200 \mathrm{kgCO} 2 \mathrm{e} / \mathrm{MWh}$. Given this variance, using standard default values fails to ensure that accepted biomass reaches GHG emission reduction goals. In addition, the U.K. only requires that GHG calculations for solid forestry residues 
only consider cultivation, processing, transportation and distribution of the biomass, and fails to include full lifecycle analysis factors such as impacts to soil carbon storage (U.K. Office of Gas and Electricity Markets, 2014). According to the DECC's lifecycle analysis of using North American residues, the electricity GHG intensity over 40 can reach above $500 \mathrm{kgCO} 2 \mathrm{e} / \mathrm{MWh}$ when using dead trees from natural disturbances and approximately $800 \mathrm{kgCO} 2 \mathrm{e} / \mathrm{MWh}$ for forest residues (assuming that the residues would have been left on the forest floor if not for being used in bioenergy processes). Even over a 100 year time period, these forest residues' GHG intensity could reach to nearly $500 \mathrm{kgCO} 2 \mathrm{e} / \mathrm{MWh}$. The report uses a GHG intensity of approximately $425 \mathrm{kgCO} 2 \mathrm{e} / \mathrm{MWh}$ for natural gas produced electricity as a reference (U.K. Department of Energy \& Climate Change, 2014a). While these forest biomass intensity values are on the high end, it demonstrates that using default values for all solid forest biomass classifications and non-lifecycle approaches for residues allows for the use of biomass that may actually be less effective at mitigating climate change than using natural gas.

Using a second certification through an organization such as RSB provides a better means to ensure that the GHG emissions of using forest biomass from the U.S. helps reduce GHG emissions. Under the current RSB standard, certified feedstock producers are required to conduct full lifecycle GHG emission calculations including data regarding land use change, above- and below-ground carbon stock changes and co-products (Roundtable for Sustainable Biomaterials, 2011). For forestry residues, this would be a significant improvement compared to the GHG calculations currently 
accepted under the RO. Another strength under RSB is that it requires operatorspecific values for data inputs for GHG calculations instead of relying on default values offered under the RO (Roundtable on Sustainable Biomaterials, 2014).

Ultimately, including a combination of SFM and RSB certification still falls short of addressing the suite of bioenergy sustainability criteria outlined by Buchholz et al. (2009). None of these schemes directly addresses issues of EROI. The aforementioned report by DECC regarding U.K. biomass imports from North America for electricity generation indicates that the likely scenarios for 2020 have an energy input to energy output ratio ranging from .13 to .96 (U.K. Department of Energy \& Climate Change, 2014a). When considering the high end of this range, some biomass imports may result in requiring approximately the same amount of energy inputs as usable energy produced. Corn-based ethanol, while EROI positive, has been consistently criticized (among other reasons) for having such a low EROI compared to other forms of biofuel. If the growth and harvest of biomass feedstocks from forests takes more energy inputs than other feedstocks to get an equivalent amount of energy output, then many could argue that the use of woody biomass is inefficient. This may have increasing relevancy when operations utilize fertilizer to achieve high yields, biomass transportation modes and distances, size reduction and densification options, biomass drying options, and perhaps even biomass species selection as tree species can vary in potential thermal value per ton.

Another remaining gap is the criteria emphasizing that biomass feedstocks should be diversified for the sake of climate change adaptation. Neither SFM 
scheme nor RSB addresses this point. Reliance on feedstocks that may be adversely impacted by climate change leaves societies open to loss of local energy sources and economic capacity. It would not be reasonable or desirable to require managers of non-plantation forests to selectively harvest or replenish feedstocks based on anticipated climate change effects. However, plantation managers could be encouraged to select for feedstock varieties based on qualities desirable to adapt to severe climate change.

\subsection{Conclusion}

Forests in the U.S. will play a significant role in providing domestic sources of energy and in major export markets seeking to achieve renewable energy goals through the use of woody biomass. Currently, forest certification schemes are used in the U.S. as a gatekeeper to gain access to domestic bioenergy markets. These certification schemes may play an increasingly important role as states increase their reliance on biomass in order to reduce carbon emissions and meet potential federal regulations through the Clean Power Plan proposed by the U.S. Environmental Protection Agency (Environmental Protection Agency, 2014). In the meantime, the U.K.'s requirement of evidence to verify the sustainability of imported wood pellets suggests forest certification schemes will play an important role in key U.S. woody feedstock production regions. Both the SFI and FSC forest certification schemes are recognized under the U.K.'s Timber Standard for Heat \& Electricity as evidence of 
the sustainability of wood pellet production and are also used in some U.S. states' renewable portfolio standards (e.g. New York) as a mechanism for approving biomass sources (New York State Energy Research \& Development Authority, 2014). However, both schemes are missing critical criteria related to sustainable bioenergy systems found in the academic literature. The overall sustainability of solid woody biomass imports to the U.K. could be improved by requiring an additional certification by a bioenergy certification standard such as RSB that focuses on core issues such as lifecycle GHG emissions, toxic air emissions, and indirectly focuses on energy balances which are missing in the SFM standards. The use of RSB's full lifecycle GHG analysis would be an improvement over the U.K.'s current GHG evaluation, particularly for the use of forest residues, an important feedstock source for imported solid biomass. Ultimately, dual certification using SFM and bioenergy sustainability schemes would bolster progress towards the U.K.'s climate change mitigation goals and improve the sustainability of importing solid woody biomass from the United States. 


\subsection{References}

Auld, G., Gulbrandsen, L. H., \& McDermott, C. L. (2008). Certification schemes and the impacts on forests and forestry. Annual Review of Environment and Resources, 33, 187-211.

Berger, A. L., Palik, B., D'Amato, A. W., Fraver, S., Bradford, J. B., Nislow, K., . . Brooks, R. T. (2013). Ecological impacts of energy-wood harvests: Lessons from whole-tree harvesting and natural disturbance. Journal of Forestry, 111(2), 139-153.

Bond, B., Lyon, S., Munsell, J., Barrett, S., \& Gagnon, J. (2014). Perceptions of Virginia's primary forest products manufacturers regarding forest certification. Forest Products Journal, 64(7), 242-249.

Buchholz, T., Luzadis, V. A., \& Volk, T. A. (2009). Sustainability criteria for bioenergy systems: results from an expert survey. Journal of Cleaner Production, 17, Supplement 1(0), S86-S98. doi: http://dx.doi.org/10.1016/j.jclepro.2009.04.015

Cambero, C., \& Sowlati, T. (2014). Assessment and optimization of forest biomass supply chains from economic, social and environmental perspectives-A review of literature. Renewable and Sustainable Energy Reviews, 36, 62-73.

Cashore, B., Egan, E., Auld, G., \& Newsom, D. (2007). Revising theories of nonstate market-driven (NSMD) governance: Lessons from the Finnish forest certification experience. Global Environmental Politics, 7(1), 1-44. 
Clark, M. R., \& Kozar, J. S. (2011). Comparing sustainable forest management certifications standards: a meta-analysis. Ecology and Society, 16(1).

Environmental Protection Agency. (2014). Clean Power Plan Proposed Rule. . from http://www2.epa.gov/carbon-pollution-standards/clean-power-plan-proposed$\underline{\text { rule }}$

Espinoza, O., Buehlmann, U., \& Smith, B. (2012). Forest certification and green building standards: overview and use in the US hardwood industry. Journal of Cleaner Production, 33, 30-41.

Forest Stewardship Council. (2010). FSC-US Forest Management Standard v1.0. Retrieved October 8, 2013, from https://us.fsc.org/download.fsc-us-forestmanagement-standard-v1-0.95.pdf

Forest Stewardship Council. (2013). Mission and vision: Protecting forests for future generations. Retrieved October 8, 2015, from www.us.fsc.org/mission-andvision.187.htm.

Forest Stewardship Council. (2015). Global FSC certificates: type and distribution. from https://ic.fsc.org/facts-figures.19.htm

Gan, J., \& Cashore, B. (2013). Opportunities and challenges for integrating bioenergy into sustainable forest management certification programs. Journal of Forestry, 111(1), 11-16.

Hoagland, K. (2014). Crossing the pond: Breaking down European pellet demand. from http://biomassmagazine.com/blog/article/2014/01/crossing-the-pondbreaking-down-european-pellet-demand. 
Hogan, G. (2013). U.K. trade in woodfuel - an overview. In T. R. A. o. t. F. C.-B. E. Center (Ed.). London, England.

Humphries, S. S., \& Kainer, K. A. (2006). Local perceptions of forest certification for community-based enterprises. Forest Ecology and Management, 235(13), 30-43.

Janowiak, M. K., \& Webster, C. R. (2010). Promoting ecological sustainability in woody biomass harvesting. Journal of Forestry, 108(1), 16-23.

Kalonga, S., Midtgaard, F., \& Eid, T. (2015). Does forest certification enhance forest structure? Empirical evidence from certified community-based forest management in Kilwa District, Tanzania. International Forestry Review, $17(2), 182-194$.

Lamers, P., Hoefnagels, R., Junginger, M., Hamelinck, C., \& Faaij, A. (2015). Global solid biomass trade for energy by 2020: an assessment of potential import streams and supply costs to North-West Europe under different sustainability constraints. GCB Bioenergy, 7(4), 618-634.

Lattimore, B., Smith, C. T., Titus, B. D., Stupak, I., \& Egnell, G. (2009). Environmental factors in woodfuel production: Opportunities, risks, and criteria and indicators for sustainable practices. Biomass and Bioenergy, 33(10), 1321-1342. doi: http://dx.doi.org/10.1016/j.biombioe.2009.06.005

Lewis, R. A., \& Davis, S. R. (2015). Forest certification, institutional capacity, and learning: An analysis of the impacts of the Malaysian Timber Certification Scheme. Forest Policy and Economics, 52, 18-26. 
Markevičius, A., Katinas, V., Perednis, E., \& Tamašauskienė, M. (2010). Trends and sustainability criteria of the production and use of liquid biofuels. Renewable and Sustainable Energy Reviews, 14(9), 3226-3231.

Miteva, D. A., Loucks, C. J., \& Pattanayak, S. K. (2015). Social and environmental impacts of forest management certification in Indonesia. PloS One, 10(7), e0129675.

Moore, S. E., Cubbage, F., \& Eicheldinger, C. (2012). Impacts of forest stewardship council (FSC) and sustainable forestry initiative (SFI) forest certification in North America. Journal of Forestry, 110(2), 79-88.

Moser, C., Hildebrandt, T., \& Bailis, R. (2014). International sustainability standards and certification. In B. D. Solomon \& R. Bailis (Eds.), Sustainable development of biofuels in Latin America and the Caribbean (pp. 27-69). New York, NY: Springer.

New York State Energy Research \& Development Authority. (2014). New York State Renewable Portfolio Standard: Biomass Power Guide. Retrieved from https://www.nyserda.ny.gov/-/media/Files/EDPPP/Energy-andEnvironmental-Markets/RPS/RPS-Documents/NYS-RPS-biomassguidebook.pdf.

Overdevest, C., \& Rickenbach, M. G. (2006). Forest certification and institutional governance: an empirical study of forest stewardship council certificate holders in the United States. Forest Policy and Economics, 9(1), 93-102. 
Pinto, L. F. G., \& McDermott, C. (2013). Equity and forest certification-A case study in Brazil. Forest Policy and Economics, 30, 23-29.

Programme for the Endorsement of Forest Certification. (2014). National Members. from http://www.pefc.org/about-pefc/membership/national-members/8$\underline{\text { United } \% 20 \text { States }}$

Rametsteiner, E., \& Simula, M. (2003). Forest certification—an instrument to promote sustainable forest management? Journal of Environmental Management, 67(1), 87-98.

Roundtable for Sustainable Biomaterials. (2011). RSB Principles \& Criteria for Sustainable Biofuel Production. Retrieved September 1, 2015, from http://rsb.org/pdfs/standards/11-03-08\%20RSB $\% 20 \mathrm{PCs} \% 20$ Version\%202.1.pdf

Roundtable on Sustainable Biomaterials. (2014). RSB GHG Calculation Methodology RSB reference code: RSB-STD-01-003-01(Version 2.1).

Sample, V. A., Price, W., \& Mater, C. M. (2003). Certification on public and university lands: evaluations of FSC and SFI by the forest managers. Journal of Forestry, 101(8), 21-25.

Scarlat, N., \& Dallemand, J.-F. (2011). Recent developments of biofuels/bioenergy sustainability certification: A global overview. Energy Policy, 39(3), 16301646.

Schepers, D. H. (2010). Challenges to legitimacy at the Forest Stewardship Council. Journal of Business Ethics, 92(2), 279-290. 
Sikkema, R., Faaij, A., Ranta, T., Heinimö, J., Gerasimov, Y., Karjalainen, T., \& Nabuurs, G. (2014). Mobilization of biomass for energy from boreal forests in Finland \& Russia under present sustainable forest management certification and new sustainability requirements for solid biofuels. Biomass and Bioenergy, 71, 23-36.

Solomon, B. D., Banerjee, A., Acevedo, A., Halvorsen, K. E., \& Eastmond, A. (2015). Policies for the sustainable development of biofuels in the Pan American region: A review and synthesis of five countries. Environmental Management, 56(6), 1276-1294.

State of Maine. (2012). Comments on Proposed Regulation 225 CMR 14.00.: Retrieved from http://www.mass.gov/eea/docs/doer/renewables/biomass/rpsregulation-comments/state-of-maine-patricia-aho-william-beardsley-kennethfletcher.pdf. .

Stupak, I., Asikainen, A., Jonsell, M., Karltun, E., Lunnan, A., Mizaraite, D., . . . Röser, D. (2007). Sustainable utilisation of forest biomass for energypossibilities and problems: policy, legislation, certification, and recommendations and guidelines in the Nordic, Baltic, and other European countries. Biomass and Bioenergy, 31(10), 666-684.

Stupak, I., Lattimore, B., Titus, B. D., \& Smith, C. T. (2011). Criteria and indicators for sustainable forest fuel production and harvesting: a review of current standards for sustainable forest management. Biomass and Bioenergy, 35(8), 3287-3308. 
Sustainable Forestry Initiative. (2015). Requirements for the SFI 2015-2019

program: Standards, rules for label use, procedures and guidance (pp. 1-123).

U.K. Department of Energy \& Climate Change. (2010). National Renewable Energy Action Plan for the United Kingdom. (Article 4 of the Renewable Energy Direct 2009/28/EC). London, England: Retrieved from https://www.gov.U.K./government/publications/national-renewable-energyaction-plan. .

U.K. Department of Energy \& Climate Change. (2012). U.K. Bioenergy Strategy. London, England: Retrieved from https://www.gov.U.K./government/ uploads/system/uploads/attachment_data/file/48337/5142-bioenergystrategy-.pdf.

U.K. Department of Energy \& Climate Change. (2013a). Government response to the consultation on proposals to enhance the sustainability criteria for the use of biomass feedstocks under the Renewables Obligation (RO).

U.K. Department of Energy \& Climate Change. (2013b). Sustainability standards for electricity generation from biomass.

U.K. Department of Energy \& Climate Change. (2013c). Use of U.K. biomass for Electricity and CHP. London, England: Retrieved from https://www.gov.U.K./government/uploads/system/uploads/attachment_data/ file/246006/U.K. wood and biomass.pdf

U.K. Department of Energy \& Climate Change. (2014a). Life cycle impacts of biomass electricity in 2020 . 
U.K. Department of Energy \& Climate Change. (2014b). Timber standard for heat \& electricity: Woodfuel used under the Renewable Heat Incentive and Renewables Obligation. (Report URN 14D/025).

U.K. Office of Gas and Electricity Markets. (2014). Renewables Obligation: Sustainability Criteria Guidance.

Vanclay, F. (2003). International principles for social impact assessment. Impact Assessment and Project Appraisal, 21(1), 5-12.

Visseren-Hamakers, I. J., \& Pattberg, P. (2013). We Can't See the Forest for the TreesThe Environmental Impact of Global Forest Certification Is Unknown. GAIA-Ecological Perspectives for Science and Society, 22(1), 25-28. 


\section{Chapter 5: Conclusions \& Directions for Future Research}

Forestlands have been identified as a valuable resource to mitigate climate change due to the biome's capacity to both sequester greenhouse gases (Beedlow et al., 2004; Bonan, 2008; Canadell \& Raupach, 2008; Sohngen \& Sedjo, 2006) and substitute for fossil fuels to produce power, heat and transportation fuels (Aguilar \& Mabee, 2014; He et al., 2014). Large scale electricity production, which accounts for the largest share of global generated greenhouse gas emissions, represents a significant opportunity for climate change mitigation (Brown \& Sovacool, 2011). Woody biomass has been proposed as a substitute input for coal as economies attempt to transition to renewable power (Dornburg \& Faaij, 2001).

In this context, my work explored two often competing foci of woody bioenergy policy: the policy framework intended to incentivize and support power production from forest biomaterials, and sustainable development challenges of the industry. The work contained in this dissertation attempts to shed some light on these complex issues with each chapter focusing on a different governmental level: local, state and international. In addition, each chapter focused on different aspects of bioenergy system social acceptance: community acceptance, socio-political acceptance, and market acceptance (Chin et al., 2014). In Chapter Three, I presented the results of a household survey that provided insight into factors influencing the public's support of local biomass production for woody biopower product. This chapter offered insight into the community acceptance of biomass harvesting at the 
local level and my results suggest that these communities are more likely to support less intensive harvesting operations and the utilization of mill and forest residues over dedicated harvesting operations. The study also suggests that communities prioritize the economic benefits when supporting biomass production; however, other forest-based ecosystem services that help to provide clean air and water are also important factors in their support of biomass production. In Chapter Two I explored more than two decades of renewable energy policy in Wisconsin to understand the lack of policy support for the woody biopower industry. This statelevel case study determined that the woody biopower industry lacked support (sociopolitical acceptance) by key stakeholders, including, but not limited to the wood products industry. This dearth of support, in addition to a demand for less coercive state regulation and cheaper electricity has resulted in a diluted state renewable portfolio standard. And in Chapter Four, I assessed the suitability of using marketoriented forest management certification programs intended to guide sustainable forest-based biomass production. This study evaluated a policy instrument intended to provide governance for the international woody biomass trade for electricity production whereby certification achieved market acceptance. The study's results indicated two certification schemes used by the United Kingdom to ensure sustainable biomass sources failed to address primary bioenergy sustainable considerations, such as net greenhouse gas emissions reductions and positive energy return on investment. 
The remainder of this chapter summarizes the woody biopower policy implications of my research and provides an overview of policy implications of the work for ecosystem services policy integration. I conclude with a brief discussion of suggestions for future work.

\subsection{Woody Biopower Development Policy Implications}

The analysis provided in Chapter Two highlights the dearth of direct supportive policies in Wisconsin for woody biopower production as the state has focused on reducing the cost of complying with the state's renewable portfolio standard and has shifted away from using direct command and control forms of regulation. However, the survey results displayed in Chapter Three highlight that rural communities like Tomahawk, WI are supportive of producing power from forest biomaterials. The support increases significantly when sources of biomass are derived from sources like logging and mill residues as well as forest operations perceive to improve forest health, such as thinning operations or procurement strategies that avoid competition with the traditional forest products industry. Presumably, these sources avoid the perceived negative association between intensive forest management for energy production (e.g. clearcutting) and the potential ill effects to landscape aesthetics while still tapping into the positive economic and benefits offered by biopower production.

The takeaway message is clear for policy makers: specific sources of biomass matter. Yet, the current policy mix in Wisconsin, dominated by its current 
RPS, generally treats all biopower sources equally. While the survey work conducted in this dissertation is restricted to Tomahawk, WI residents, and thus should not be generalized beyond this scope, state policy makers should take note of the underlying attitudinal trends and craft definitions for renewable biomass sources and incentive structures accordingly. Clarifying these definitions and pursuing biomass source specific policies may help build coalitions between environmental, forestry, and recreation groups to spur woody biopower policy development which, as Chapter Three demonstrated, have historically been missing in energy policy development in Wisconsin.

The findings from Chapter Two also highlight that Wisconsin lawmakers' willingness to rely on coercive regulatory policies within the renewable energy policy mix has declined over the past two decades. Given this aversion to direct command and control regulation, non-state market driven-governance certification schemes present an alternative avenue to address sustainable biopower generation (Cashore et al., 2007). The state of Wisconsin has turned to sustainable forestry management certification schemes to ensure traditional wood products generated from Wisconsin forests meet downstream sustainability requirements of contractors, paper products industry and manufacturers (Wisconsin Department of Natural Resources, 2018). The demand for sustainably produced wood products is being made by consumers. In response, the State of Wisconsin requires that forests under Department of Natural Resource (DNR) and County management be dual certified by both the Forest Stewardship Council (FSC) and the Sustainable Forestry Initiative 
(SFI) certification schemes. In addition, non-industrial private forest (NIPF) owners participating in the state's Managed Forest Law (MFL) tax reduction program are also certified under FSC or the American Tree Farm System standards. However, state policies guiding renewable power generation, including the Wisconsin RPS, have no such requirement. In fact, under Wisconsin Statute $\S 196.378(1)($ ar) and Wisconsin Statute $\S 196.378(1)(\mathrm{h})$ which defines "biomass" and eligible "renewable resources" respectively for the RPS, no guidance or requirement for sustainable biomass sourcing is included.

This highlights a particularly vexing challenge when states rely on non-state market governance for sustainable electricity production. On the one hand, Wisconsin's participation in third-party certification programs is driven by requirements put in place predominately by private sector businesses seeking to address customers' demand for sustainable traditional forest products (Wisconsin Department of Natural Resources, 2018). In this case, the government sees its role as a facilitator to ensure the competitiveness of its forest products industry. On the other hand, the provisioning of electricity to end use customers is opaquer. Despite increasing demand for renewable energy, the economic pressures to participate in sustainable bioenergy or forest management schemes appear to not have taken root in Wisconsin. One potential explanation could be consumers' incapacity to easily choose between competing electricity providers. Whereas consumers can easily opt for certified paper products over non-certified products, utility customers in Wisconsin are faced with a monopolistic provision of electricity with few 
opportunities to "vote with their wallets". Therefore, the requisite market forces may be absent and explain the state's lack of adoption of certification programs for biopower production. However, as Chapter Four highlights, these schemes may still fall short of many energy-specific sustainability criteria.

\subsection{Policy Implications for Ecosystem Services Policy Integration}

In the United States, the incorporation of the ecosystem services framework in land use policies and decision making has lagged behind the international community. However, it has accelerated in recent years thanks to an uptake by nongovernmental organizations, academia and the federal government (Schaefer et al., 2015). While extensive efforts to develop robust analytical tools such as Stanford University's Integrated Valuation of Environmental Services and Tradeoffs (InVEST) have given policy makers the ability to evaluate the inherent tradeoffs between various land use scenarios, geographic- and project-specific valuation inputs, both qualitative and

quantitative are often in short supply because of financial, temporal, and institutional constraints (Braat \& de Groot, 2012; Burkhard et al., 2012; Schaefer et al., 2015).

Chapter Three demonstrates an approach to generate socio-cultural data to help value ecosystem tradeoffs using the case of biopower production in Tomahawk, WI. It may be particularly helpful for state and federal officials operating in communities where transferrable monetary valuation inputs of ecosystem services from previous studies are lacking. This is often a challenge because previous case 
study communities can contain differences in sociodemographic (e.g. income, education, values, etc.) make-up and ecosystem services levels that could result in significant variation in benefit values.

The results from my work can provide guidance to policy makers and program managers developing incentives to protect forest-based ecosystem services, including payment for ecosystem service schemes as well opportunities for public education and engagement (Asah et al., 2014). While much of biomass harvesting operates on timber investment management organization (TIMO) and NIPF land, forests under state and county ownership are still sources for biomass production. The values generated from this study can be incorporated in spatially explicit forest management models to highlight how the general public perceives and values potential tradeoffs influencing forest-based ecosystem services. This can be done by assigning socio cultural preference values to spatially referenced ecosystem service provision units using land cover layers as demonstrated by geographic information system (GIS) multi-criteria decision making models from previous studies (Bryan et al., 2010; Seppelt et al., 2011).

\subsection{Future Research}

The production of energy from forest biomaterials, like most forms of natural resource management, is immersed in a complex web of social, economic, and ecological goals and challenges. My dissertation offers only a narrow glimpse into some of the vexing policy issues facing its effective and sustainable implementation. 
However, opportunities to expand upon this work and enhance its value to policy makers and fellow scientists are numerous.

In Chapter Two, I discussed actors' ability to reduce regulatory requirements of Wisconsin's RPS by adding successive policy layers, which resulted in a form of policy dismantling. Future work should focus on applying this new theory of policy dilution to other case studies within and outside the energy policy realm to explore conditions that help to facilitate or prevent this practice. Testing the theory can be done in multiple ways. First, additional case studies can be developed focusing on entrenched regulatory frameworks where formal policy dismantling efforts are difficulty to achieve. Additional work, through interviews and surveys of policy makers and regulated industry officials, should be conducted to research if policy dilution is an intentional, proactive strategy and if so, what conditions lead to the selection and success of the strategy. In the context of woody biopower production, I viewed this practice in a negative light because of its reduction in the policy mix's capacity to support in-state renewable power generation; however, future work should also consider the possibility that layering resulting in dilutive effects could also be a positive means to address incoherent and incongruent policy arrangements (Wellstead et al., 2016).

Chapter Three explored the application of the ecosystem service framework as a means to better understand community member support for local forest biomass power production. Future research efforts should evaluate the validity of these findings through additional case studies in different natural resource management, 
geographic and socioeconomic contexts. Doing so would help to refine measures used to apply this framework and advance social acceptance and ecosystem service theory by identifying conditions in which models tested in Tomahawk, WI hold true or unravel. The contribution of this work would be further strengthened by crossreferencing or ground truthing the findings with target audiences, such as policy makers, forest managers, and advocacy groups who play more transparent role in natural resource management policy implementation at local, state and federal levels. Doing so could shed light on the actual influence of these preferences in policy development and implementation, a much debated question (Burstein, 2003), as well as help develop approaches to better incorporate these preferences in policies and forest management sustainability frameworks pertaining to forest biomass production. Research should also focus on identifying and addressing state and local forest managers' capacity to incorporate the ecosystem service framework into their policy processes (Portman, 2013).

Chapter Three also offered an empirical analysis of factors underlying support for forest biomass production for biopower generation. While market and techno-economic conditions play a significant role in the viability of biomass as input for power production, more work is left to be done to explore the complexities of social acceptance of specific forest biomass sources. The work contained in this dissertation would be advanced by better understanding individuals' perceptions of positive and negative effects of alternative harvesting scenarios (e.g. thinning operations vs. timber harvesting residue removal) and the influence of harvesting 
intensity and geography. This would help to inform spatially explicit decisionmaking models needed for more effective land use management (Burkhard et al., 2012). Integrating this information with ecological and economic effects of these different biomass sources will give policy makers a more robust understanding of tradeoffs resulting from alternative biomass production scenarios (Braat \& de Groot, 2012). 


\subsection{References}

Aguilar, F. X., \& Mabee, W. (2014). A renewable source of energy. In F. X. Aguilar (Ed.), Wood Energy in Developed Economies: Resource Management, Economics and Policy (pp. 1-31). Abingdon, UK and New York, NY: Routledge.

Asah, S. T., Guerry, A. D., Blahna, D. J., \& Lawler, J. J. (2014). Perception, acquisition and use of ecosystem services: Human behavior, and ecosystem management and policy implications. Ecosystem Services, 10, 180-186.

Beedlow, P. A., Tingey, D. T., Phillips, D. L., Hogsett, W. E., \& Olszyk, D. M. (2004). Rising atmospheric CO2 and carbon sequestration in forests. Frontiers in Ecology and the Environment, 2(6), 315-322.

Bonan, G. B. (2008). Forests and climate change: Forcings, feedbacks, and the climate benefits of forests. Science, 320(5882), 1444-1449.

Braat, L. C., \& de Groot, R. S. (2012). The ecosystem services agenda: Bridging the worlds of natural science and economics, conservation and development, and public and private policy. Ecosystem Services, 1(1), 4-15.

Brown, M. A., \& Sovacool, B. K. (2011). Climate change and global energy security: technology and policy options. Cambridge, MA: MIT Press.

Bryan, B. A., Grandgirard, A., \& Ward, J. R. (2010). Quantifying and exploring strategic regional priorities for managing natural capital and ecosystem services given multiple stakeholder perspectives. Ecosystems, 13(4), 539-555. 
Burkhard, B., De Groot, R. S., Costanza, R., Seppelt, R., Jorgensen, S. E., \& Potschin, M. (2012). Solutions for sustaining natural capital and ecosystem services. Ecological Indicators, 21, 1-6.

Burstein, P. (2003). The impact of public opinion on public policy: A review and an agenda. Political Research Quarterly, 56(1), 29-40.

Canadell, J. G., \& Raupach, M. R. (2008). Managing forests for climate change mitigation. Science, 320(5882), 1456-1457.

Cashore, B., Egan, E., Auld, G., \& Newsom, D. (2007). Revising theories of nonstate market-driven (NSMD) governance: Lessons from the Finnish forest certification experience. Global Environmental Politics, 7(1), 1-44.

Chin, H.-C., Choong, W.-W., Alwi, S. R. W., \& Mohammed, A. H. (2014). Issues of social acceptance on biofuel development. Journal of Cleaner Production, 71, 30-39.

Dornburg, V., \& Faaij, A. P. C. (2001). Efficiency and economy of wood-fired biomass energy systems in relation to scale regarding heat and power generation using combustion and gasification technologies. Biomass and Bioenergy, 21(2), 91-108.

He, L., English, B. C., Daniel, G., \& Hodges, D. G. (2014). Woody biomass potential for energy feedstock in United States. Journal of Forest Economics, 20(2), 174-191. 
Portman, M. E. (2013). Ecosystem services in practice: challenges to real world implementation of ecosystem services across multiple landscapes-a critical review. Applied Geography, 45, 185-192.

Schaefer, M., Goldman, E., Bartuska, A. M., Sutton-Grier, A., \& Lubchenco, J. (2015). Nature as capital: Advancing and incorporating ecosystem services in United States federal policies and programs. Proceedings of the National Academy of Sciences of the United States of America, 201420500.

Seppelt, R., Dormann, C. F., Eppink, F. V., Lautenbach, S., \& Schmidt, S. (2011). A quantitative review of ecosystem service studies: Approaches, shortcomings and the road ahead. Journal of Applied Ecology, 48(3), 630-636.

Sohngen, B., \& Sedjo, R. (2006). Carbon sequestration in global forests under different carbon price regimes. The Energy Journal, 27, 109-126.

Wellstead, A., Rayner, J., \& Howlett, M. (2016). Alberta's oil sands reclamation policy trajectory: The role of tense layering, policy stretching and policy patching in long-term policy dynamics. Journal of Environmental Policy and Planning, 59(10), 1873-1890.

Wisconsin Department of Natural Resources. (2018). Forest certification. Retrieved July 28, 2018, from https://dnr.wi.gov/topic/TimberSales/certification.html 